\title{
DA POESIA CONCRETA AO POEMA-PROCESSO: UM PASSEIO PELO FIO DA NAVALHA
}

Dissertação de Mestrado apresentada à Faculdade de Filosofia, Letras e Ciências Humanas da Universidade de São Paulo, na área de Literatura Brasileira, sob a orientação do Prof. Dr. João Adolfo Hansen. 
Para Heloísa e Helotônio.

Para meu pai, na terceira margem do rio. 


\section{AGRADECIMENTOS}

A João Adolfo Hansen: orientação, diálogo e bom-humor.

A Celso Fernando Favaretto, pela grande ajuda bibliográfica, diálogos, sugestões e correções.

A Alcides Celso Oliveira Villaça, pelas leituras atentas e comentários sempre reveladores.

A minha mãe, Heloísa Helena, pelo apoio constante e preocupação.

A meu pai, Antônio, pelos raros momentos de diálogo e atenção.

A meu irmão, Helotônio: amizade, colaboração e incentivo.

Aos amigos Danilo Tovo Ortigoso, Flávio Felício Botton, Petruska Castelo

Chaves, Regina Venâncio e Sônia Amaral.

A Denise Ceron, pelas sugestões e trabalhos de revisão.

A Izabel C. S. Monteiro: amizade, estímulo e paciência. 


\section{RESUMO}

A proposta desta dissertação é discutir a polêmica trajetória das vanguardas poéticas brasileiras, representadas pela poesia concreta, neoconcreta, praxis e poema-processo, com base na análise de alguns procedimentos técnicos, conceitos teóricos e princípios formais apresentados nos principais textos (manifestos e plataformas) e práticas poéticas desses movimentos.

Feita uma revisão crítica do conceito de vanguarda e suas aporias no contexto da crise do Modernismo na segunda metade do século XX, foram discutidos alguns impasses estético-políticos, teóricos e práticos dessa poesia de vanguarda, diante do cenário sociocultural brasileiro dos anos 1950 e 1960. Se, por um lado, a necessidade programática de afirmar o "novo" nos grupos vanguardistas lançou alguns procedimentos técnicos e princípios formais que, principalmente com a poesia concreta, incidiram no campo da crítica literária e do ensino das letras nas universidades, por outro, retomou e radicalizou velhas categorias futuristas, cubistas, construtivistas e modernistas de 1922. 


\section{ABSTRACT}

The proposal of this dissertation is to discuss the polemic course of Brazilian poetry avant-gardes, represented by Concrete, Neoconcrete, Praxis and Process poetries, based on the analysis of some technical procedures, theoretical concepts and formal principles presented in the main texts (manifests and platforms) and poetical practices in these movements.

After a critical revision of the concept of avant-garde and its contradictions in the context of the Modernism crisis in the second half of the $20^{\text {th }}$ century, we discussed some esthetic-political, theoretical and practical deadlocks, inside the sociocultural Brazilian scenario during the 1950s and 1960s. If, on one side, the need of stating the "new" in the avant-garde groups created some technical procedures and formal principles that, notably with the concrete poetry, targeted the fields of literary critics and teaching literature at universities, on the other side, resumed and radicalized old futurist, cubist, constructivist and 1922 modernist categories. 
A necessidade de tomar riscos actualiza-se na idéia do experimental que, simultaneamente, transfere da ciência para a arte a utilização consciente dos materiais contra a concepção de um procedimento orgânico inconsciente. Actualmente, a cultura oficial concede um espaço particular ao que ela, com desconfiança, considera como experimentação, aguardando já em parte o seu insucesso e assim a neutralizando.

Theodor Adorno (1970, 51)

Mas de qualquer modo, esta poesia de vanguarda representa de maneira viva o passeio pelo fio da navalha... 


\section{SUMÁRIO}

APRESENTAÇÃO _

1. CONSIDERAÇÕES INICIAIS __ 3

1.1. Vanguarda em questão: conceito e aporias ___ 3

1.2. As vanguardas poéticas no contexto brasileiro: anos 1950-1960___ 11

1.2.1. Artes visuais, poesia e ideologias ___ 11

1.2.2. Vanguardas poéticas e situação literária ___ 22

2. DA POESIA CONCRETA AO POEMA-PROCESSO _ 29

2.1. Poesia concreta

2.2. Poesia neoconcreta

2.3. Poesia Praxis _ 81

2.4. Poema-Processo___ 104

3. (IN)CONCLUSÃO

POSFÁCIO 130

BIBLIOGRAFIA__ 131

Especifica _ 131

Geral _ـ 137 


\section{APRESENTAÇÃO}

Esta dissertação resulta de uma reflexão crítica sobre a presença polêmica da poesia de vanguarda brasileira de tendência experimental, geralmente considerada "formalista", representada pelas poesias concreta, neoconcreta, praxis e pelo poema-processo, no contexto brasileiro dos anos 1950 e 1960. A preocupação central desses movimentos foi incorporar dados novos de um contexto universal a uma problemática da cultura nacional, com a experimentação de "novas" formas de poesia, e criticar a prática e o consumo da poesia escrita em verso, metrificado ou livre.

O propósito deste estudo foi, portanto, identificar nos procedimentos técnicos e conceitos teóricos da poesia de vanguarda brasileira algumas de suas aporias e discutir suas possíveis contribuições (ou não) - o eventual alcance crítico - para o sistema literário brasileiro.

Esta dissertação divide-se em duas partes. A primeira, que consta de três momentos, oferece ao leitor um conjunto de informações que vão desde as reflexões críticas sobre o conceito original da palavra "vanguarda" e suas aporias, segundo a análise dos principais críticos da arte de vanguarda, passando pela genealogia da poesia de vanguarda brasileira e sua relação com as ideologias estético-políticas no Brasil da época, até um exame sobre as possíveis contribuições das neovanguardas brasileiras para a situação literária brasileira dos anos 1950 e 1960. A segunda parte é dedicada à leitura e à análise dos principais textos teóricos e programáticos e de alguns poemas, não apenas com o objetivo de identificar os modos como as neovanguardas teorizam a história, mas também de observar algumas contradições teóricas e práticas presentes em cada movimento.

Por fim, em se tratando de uma sugestão de leitura e reflexão crítica sobre um tema ainda muito polêmico e em discussão, sugeriu-se uma in(conclusão), que retoma as questões já levantadas no decorrer deste estudo e propõe outras, a fim de contribuir para o debate sobre as estéticas da arte de vanguarda brasileira. 


\section{CONSIDERAÇÕES INICIAIS}

\subsection{Vanguarda em questão: conceito e aporias}

Originalmente, o termo "vanguarda" designa parte de um exército que avança na linha de frente de um combate para se antecipar ao corpo principal de soldados e defendê-lo. Segundo Hans Magnus Enzensberger, ${ }^{1}$ a palavra passou da noção de estratégia militar para as artes por volta dos anos 50 do século XIX, na França revolucionária. No discurso da crítica de arte, a atividade artística vinculouse ao ativismo político (o artista deve comprometer-se com a participação nas lutas sociais). A partir desse momento, a palavra "vanguarda" assume um sentido figurado que vai ocultar seu significado original.

Enzensberger faz a crítica da vanguarda com base na análise de suas aporias que já estão inscritas na própria palavra composta avant-garde. Originalmente, avant tem um sentido espacial. Empregada metaforicamente, a partícula ganha uma referência temporal. $\mathrm{O}$ aspecto temporal está diretamente associado à idéia de mudança (inovação, avanço, antecipação). Para o autor, “o 'avançar' da vanguarda quer realizar simultaneamente o futuro no presente, antecipar-se ao curso da história". ${ }^{2}$ Sendo assim, precedida pelo projeto, a obra só se completa no futuro. O "avançar" só pode ser comprovado no futuro, eis a sua própria contradição.

Além das implicações temporais, sociologicamente, o termo garde pode significar "guarda pessoal de príncipes" e também "tropa de elite de um exército"; ambas conotam a idéia de coletividade, porém, normalmente, apresentam seu líder. Compõem, assim, um grupo distinto, que se considera "elite".

O poeta e crítico alemão lembra que, meio século depois, em 1919, a noção de "vanguarda" foi aplicada muito precisamente à política por Lênin, que "definiu o

\footnotetext{
1 “As aporias da vanguarda”. Tempo Brasileiro, n.26-27, jan./mar. 1971, p.92.

${ }^{2}$ Idem, p.93.
} 
partido comunista como 'a vanguarda do proletariado' (...) um grupo de combate, fortemente organizado, composto por uma elite, para a qual uma disciplina interna rigorosa é bem natural; igualmente natural é o estatuto privilegiado que lhe parece diante da massa dos que estão fora do partido. (...) Somente num ponto, o sentido figurado se afasta do sentido primitivo: a vanguarda comunista não tem que se regular pela marcha do grosso das tropas, mas, inversamente, ela é ao mesmo tempo Estado Maior cujos planos devem comandar toda a operação. (...) O que está 'adiante' é definido uma vez por todas por uma doutrina infalível, e o adversário contra o qual é dirigido o ataque é bem determinado e existe realmente". 3

Se em Lênin a aplicação da idéia de vanguarda à política se mostrou precisa, nas artes não se pode dizer o mesmo, pois a impressão é de algo confuso. Ao mesmo tempo em que há um esforço coletivo, há também uma idéia falsa de tropa organizada, disciplinada, que vai à frente. Os participantes de um movimento de vanguarda se relacionam com o movimento total, sem intermediários que assumam seu risco pessoal. Quanto à idéia de "revolução", o autor observa que não há referência a ela na metáfora de vanguarda; no entanto, todos os grupos trazem em seus programas protestos contra a ordem estabelecida e, rompendo com essa ordem, "prometem a liberdade mediante a revolução". ${ }^{4}$ Porém, como essa liberdade nas artes é estabelecida de forma doutrinária pela vanguarda, a idéia de "revolução" permanece vaga e confusa.

Enzensberger nota ainda que, no aspecto temporal, o problemático avançar da vanguarda foi rapidamente esvaziado diante de uma apropriação neutralizadora da indústria cultural nas sociedades capitalistas. Paralelamente, a partir dos anos 1940-1950, houve uma redução progressiva da experimentação estética a um fim em si mesmo. O autor observa que, nos anos 1950-1960, movimentos como o tachismo, a pintura monocromática, a música eletrônica, a poesia concreta, a literatura beat etc. tinham em comum a formação coletiva, o caráter doutrinário e a convicção de estar "adiante". Em cumplicidade com a indústria cultural, ao mesmo

\footnotetext{
${ }^{3}$ Idem, p.99-100.

${ }^{4}$ Idem, p. 101.
} 
tempo em que reivindicaram o estatuto de vanguarda, esses movimentos utilizaramno de forma publicitária e doutrinária:

Idéia lógica em si mesma, a vanguarda se propôs sempre o movimento, não somente no sentido histórico-filosófico, mas igualmente no sentido sociológico. Cada um de seus grupos não acreditou somente em antecipar uma fase do processo histórico, mas além disso se considerou como movimento. No duplo sentido da palavra, este movimento se proclama agora como um fim em si mesmo. O parentesco com os movimentos totalitários salta aos olhos, o essencial destes sendo precisamente, como mostrou Hannah Arendt, o movimento para o vazio que emite exigências ideológicas perfeitamente arbitrárias, ou antes manifestamente absurdas, e as transporta para os fatos. ${ }^{5}$

As vanguardas dos anos 1950-1960, para Enzensberger, retomam o que já havia sido formulado pelas primeiras vanguardas do início do século $\mathrm{XX}$, no que se refere à idéia de "vanguarda" como grupo unido a uma doutrina e disposto a romper com a ordem estabelecida:

Todas as vanguardas de hoje não são senão repetição, embuste para com as outras ou para consigo mesmo. O movimento, que como grupo unido a uma doutrina, nascido há cinqüenta ou trinta anos com o propósito de romper com a resistência que uma sociedade compacta oferecia à arte moderna, não sobreviveu às condições históricas que o tornaram possível. Conspirar em nome das artes não é possível senão onde elas sofrem opressão. Uma vanguarda a que os poderes oficiais favorecem é uma vanguarda que perdeu o direito de sê-lo. (...)

A acusação que se deve fazer à vanguarda de hoje é, não a de ir longe demais, porém de manter as portas abertas atrás dela, de procurar apoio em doutrinas e coletividades, de não ser consciente de suas próprias aporias, desde há muito resolvidas pela história. Ela faz comércio de um futuro que não lhe pertence. Seu movimento não é senão regressão. A vanguarda se transformou no seu oposto, ela se tornou anacronismo. $\mathrm{O}$ risco pouco visível, mas infinito, em que vive o futuro das artes, ela recusa assumir. ${ }^{6}$

Contemporâneo a Enzensberger, Edoardo Sanguineti também faz uma análise da vanguarda, em termos marxista, com base em suas aporias, porém se

\footnotetext{
${ }^{5}$ Idem, p.105.

${ }^{6}$ Idem, p.112.
} 
volta mais para o que chama de "conflito econômico". Em seu livro Ideologia e linguagem, Sanguineti observa um duplo movimento interno da vanguarda representado por dois momentos só aparentemente contraditórios: no primeiro, denominado "heróico e patético", o produto artístico tenta fugir ou finge fugir ao jogo da oferta e da procura; no segundo, denominado "cínico", o produto artístico assume a sua existência própria, natural e efetiva de mercadoria, perde seu caráter de novidade em concorrência com outras mercadorias e acaba neutralizado. ${ }^{7}$ Segundo o teórico, "a vanguarda questiona a neutralização mercantil, forçando as contradições existentes em sua heteronímia, não importa se heróica ou cinicamente, o que importa é que ela exprime o momento dialético no interior da neutralização assinalada pela mercantilização estética". ${ }^{8}$

Observa-se que tanto para Enzensberger como para Sanguineti o avançar da vanguarda, no seu sentido metafórico em direção ao novo, acaba, num movimento contraditório, promovendo sua própria neutralização. Situada entre o academicismo beletrista e o kitsch de massa, a vanguarda tem como projeto o rompimento com a tradição e a afirmação do novo. Assim, acaba reproduzindo contraditoriamente o movimento mesmo do capital, que é, ele sim, revolucionário das ciências e técnicas.

Theodor Adorno também discutiu a arte na sociedade industrial capitalista. É importante ressaltar que o conceito de arte moderna para Adorno - única arte legítima do presente - engloba os antecedentes dos movimentos de vanguarda (a partir de Baudelaire), os próprios movimentos e as neovanguardas. ${ }^{9}$ A obra de vanguarda é analisada como "expressão necessária da alienação na sociedade capitalista avançada". ${ }^{10}$ No centro da teoria de Adorno sobre a arte moderna, encontra-se a categoria do "novo". O novo é a renovação dos temas, motivos e processos artísticos estabelecidos pela evolução da arte desde a modernidade. Essa categoria representa a hostilidade contra a tradição peculiar da sociedade burguesa

\footnotetext{
${ }^{7}$ Porto, Portucalense, 1972, p.57-59.

${ }^{8}$ Apud ARANTES, Otília. "Depois das vanguardas". Arte em Revista, ano 5, n.7, ago. 1983, p.11.

${ }^{9}$ A interpretação é de Peter Bürger (Teoria da vanguarda, 1.ed., Lisboa, Vega, 1993, p.136).

${ }^{10}$ Idem, p. 146.
} 
capitalista. Em Teoria estética, escrito em 1968, última obra do pensador, a vanguarda pode ser traduzida como o experimental:

A violência do Novo, para o qual se adoptou o nome de processo experimental, não deve imputar-se ao pensamento subjetivo ou à natureza psicológica do artista. Onde nem as formas nem os conteúdos determinam este ímpeto, os artistas produtivos são objetivamente compelidos à experimentação. No entanto, o conceito de experimentação modificou-se em si, e de maneira exemplar para as categorias do Moderno. Originalmente, ele significava apenas que a vontade consciente de si mesma experimentava processos técnicos desconhecidos ou não sancionados. Tradicionalmente, estava subjacente a crença de que tornaria público se os resultados se impunham ao que já estava estabelecido e se legitimava. Esta concepção da experimentação artística tornou-se tão evidente como problemática na sua confiança na continuidade. O gestus experimental, termo que designa os procedimentos artísticos para os quais o Novo é obrigatório, manteve-se, mas hoje designa de muitos modos, com a passagem do interesse estético da subjetividade comunicativa para a consonância do objecto, algo de qualitativamente outro: o facto de que o sujeito artístico pratica métodos cujos resultados concretos não pode prever. ${ }^{11}$

Deve-se lembrar que as vanguardas das primeiras décadas do século $\mathrm{XX}$, ao romperem com a tradição das Belas-Artes, fizeram uma crítica frente aos valores instituídos e introduziram novos procedimentos e possibilidades de fazer arte: "parecia possível fazer tudo, com tudo, em qualquer direção". ${ }^{2}$ Essa aparente desorganização é o "selo de autenticidade do Modernismo.(...) A energia antitradicionalista transforma-se em turbilhão devorador. Nesta medida o Moderno é um mito voltado contra si mesmo; a sua intemporalidade torna-se catástrofe do instante que rompe a continuidade temporal. O conceito de Benjamin de 'imagem dialética' encerra este momento. Mesmo quando o Moderno conserva, enquanto técnicas, aquisições tradicionais, estas são suprimidas pelo choque que deixa nenhuma herança intacta. Assim como a categoria do Novo resultava do processo histórico, que dissolve primeiro a tradição específica, em seguida, toda e qualquer tradição, assim o Moderno não é nenhuma aberração que se deixaria corrigir,

\footnotetext{
${ }^{11}$ Lisboa, Edições 70, 1993, p.36.

${ }^{12}$ Cf.BRITO, Ronaldo. "O moderno e o contemporâneo (o novo e o outro novo)". In:VVAA. Arte Brasileira Contemporânea. Caderno de Textos 1. Rio de Janeiro, Funarte, 1980, p.5.
} 
regressando a um terreno que já não existe e não mais deve existir; isto é paradoxalmente o fundamento do Moderno e confere-lhe $\mathrm{o}$ seu caráter normativo." ${ }^{13}$ Visto assim, o Moderno produziu uma situação contraditória: ao mesmo tempo que rompeu com a tradição e com a continuidade temporal, inaugurou uma nova tradição, a Tradição do Novo, como chamou Harold Rosenberg. ${ }^{14}$ Institucionalizadas, as obras da Modernidade transformaram-se em figuras ideais, modelos, seguindo uma cronologia de movimentos que permitiu o encadear de semelhanças, conflitos e oposições. Os procedimentos e materiais que pareciam "inaceitáveis" foram incorporados à tradição e à História da Arte. Sob o signo do Moderno e do novo, o "gestus experimental", em sua necessidade de tomar riscos, "pratica métodos cujos resultados concretos não pode prever". ${ }^{15}$ Consciente da perda de poder e controle que adveio da tecnologia libertada, o sujeito precisava dominar a multiplicidade de materiais e integrá-la ao ponto de partida subjetivo para torná-la um momento do processo de produção. "O produto vaporoso da imaginação pode, por seu lado, enquanto meio artístico específico, ser imaginado na sua imprecisão." 16 Deve-se ressaltar que a análise de Theodor W. Adorno sobre o Moderno e o experimental considera a produção artística da sociedade capitalista avançada.

Num outro contexto, as vanguardas poéticas brasileiras dos anos 1950 e 1960, ainda sob o signo do novo Moderno e impulsionadas pela euforia dos anos 50, tentaram retomar e recodificar, num processo semelhante de invenção, muitos dos procedimentos das vanguardas européias. Esse assunto, porém, será discutido mais adiante.

Peter Bürger é outro teórico que merece destaque nas reflexões sobre a vanguarda. Na primeira parte de sua Teoria da vanguarda, ${ }^{17}$ Bürger propõe uma

\footnotetext{
${ }^{13}$ ADORNO, Theodor W. Op.cit., p.35.

${ }^{14}$ Cf. ROSENBERG, Harold. A Tradição do Novo. São Paulo, Perspectiva, 1974.

${ }^{15}$ ADORNO, Theodor W. Op. cit., p.36.

${ }^{16}$ Idem, ibidem.

${ }^{17}$ Lisboa, Vega, 1993. Algumas das principais teses de Bürger foram resumidas e comentadas por Iumna Maria Simon, no artigo "Esteticismo e participação: as vanguardas poéticas no contexto brasileiro (19541969)" (in América Latina: palavra, literatura e cultura: vanguarda e modernidade, org. por Ana Pizarro, Campinas, Memorial/Unicamp, 1995, 3v., p.355-356).
} 
discussão sobre os movimentos históricos de vanguarda do início do século $\mathrm{XX}$ com base em suas tentativas de transgredir os limites da arte como instituição e romper com a idéia da arte como representação.

O estudioso estabelece duas teses principais: 1) "a vanguarda permite reconhecer determinadas categorias gerais da obra de arte na sua generalidade, e que portanto a partir da vanguarda podem ser conceptualizados os estádios precedentes no desenvolvimento do fenômeno arte na sociedade burguesa, mas não o inverso"; 2) "o subsistema artístico atinge, com os movimentos de vanguarda européia, o estádio da autocrítica". ${ }^{18}$ E cita exemplo: "O dadaísmo, o mais radical dos movimentos da vanguarda européia, já não critica as tendências artísticas precedentes, mas a instituição arte tal como se formou na sociedade burguesa". ${ }^{19}$

Bürger esclarece que o pleno desenvolvimento da instituição arte na sociedade burguesa, chamado de esteticismo, atinge seu apogeu quando rompe com a sociedade vigente e cria um subsistema autônomo, ${ }^{20}$ caracterizado pelo aspecto individual da produção artística e pela obra de arte que se transforma no conteúdo da arte.

Com isso, o esteticismo torna-se a condição prévia para a intervenção das vanguardas européias que negam a autonomia da arte burguesa e propõem a aproximação da arte à práxis vital. "A intenção dos vanguardistas pode definir-se como sendo a tentativa de devolver a experiência estética (oposta à práxis vital), criada pelo esteticismo, à prática."21

Peter Bürger observa, no entanto, que as vanguardas das décadas de 1950 e 1960, denominadas neovanguardas, não atingiram o mesmo valor de protesto e efeito de choque que as vanguardas históricas, embora possam ter sido mais bem realizadas que as primeiras. Mas vale notar que "a neovanguarda institucionaliza a vanguarda como arte e nega assim as genuínas intenções vanguardistas. (...) A arte

\footnotetext{
${ }^{18}$ Cf. op. cit., p.47-48.

${ }^{19}$ Idem, p.51.

${ }^{20}$ Idem, p.65-66.

${ }^{21}$ Idem, p.66.
} 
neovanguardista é arte autônoma no pleno sentido da palavra, e isto significa que nega a intenção vanguardista de uma reintegração da arte na práxis vital". ${ }^{22}$

Bürger declara ainda que as neovanguardas contradizem as intenções dos movimentos históricos de vanguarda (romper com a instituição arte), por isso elas podem ser vistas como afirmação de uma regressão, um anacronismo. Ao institucionalizar a vanguarda como arte, as neovanguardas cumprem o destino que lhes está reservado: já nascem historicizadas. A "novidade duvidosa", sempre à sombra do novo produzido pelas vanguardas históricas, faz de seus avanços patentes recuos que deveriam prever sua morte prematura.

$\mathrm{O}$ destino reservado às neovanguardas, como se viu, já está previsto no próprio conceito bélico da palavra "vanguarda": o grupo que avança heroicamente na frente já deve prever que cumpre uma missão suicida. Porém, como se observou na análise dos teóricos, as neovanguardas parecem ignorar tal sina. Ao assumir a posição de vanguardista na busca incessante pelo "novo", a poesia de vanguarda brasileira não está isenta do mesmo destino. Num contexto totalmente inverso, sem a presença do capitalismo industrial avançado e da massificação, restou à vanguarda poética brasileira, num quadro de atraso social próprio do subdesenvolvimento, idealizar uma situação de desenvolvimento. ${ }^{23}$ Os países desenvolvidos tornam-se o espelho dos vanguardistas brasileiros, como observou Ferreira Gullar:

Mas essas "vanguardas" trazem em si, embora equivocadamente, a questão do novo, e essa é uma questão essencial para os povos subdesenvolvidos e para os artistas desses povos. A necessidade de transformação é uma exigência radical para quem vive numa sociedade dominada pela miséria e quando se sabe que essa miséria é produto de estruturas arcaicas. Grosso modo, somos o passado dos países desenvolvidos e eles são o espelho de nosso futuro. ${ }^{24}$

\footnotetext{
${ }^{22}$ Idem, p. 105.

${ }^{23}$ Cf. SIMON, Iumna Maria, art. cit., p.358.

${ }^{24}$ In: Vanguarda e subdesenvolvimento. Rio de Janeiro, Civilização Brasileira, 1969, p.23.
} 
Além de sofrer as aporias próprias de toda vanguarda, a poesia de vanguarda brasileira confronta-se ainda com a questão do subdesenvolvimento. Essa e outras questões são, no entanto, assunto dos próximos itens.

\subsection{As vanguardas poéticas no contexto brasileiro: anos 1950-1960}

\subsubsection{Artes visuais, poesia e ideologias}

A I Exposição de Arte Concreta, ${ }^{25}$ inaugurada em dezembro de 1956 no MAM (Museu de Arte Moderna) de São Paulo (em janeiro de 1957, foi realizada no MAM do Rio de Janeiro), marca o surgimento da poesia concreta. Essa exposição, que reuniu artistas plásticos e poetas do Rio de Janeiro e de São Paulo, não só revelou as diferenças entre as experiências dos grupos paulista e carioca, mas também permitiu observar algumas semelhanças entre a poesia e a pintura concretas: Mário Pedrosa observou que "os poetas concretistas aproximam-se das artes plásticas, aproximam-se da música para alcançar a nudez de percepção, a virgindade e a pureza do golpe inicial, global, perceptivo das gestalts. Eis por que sofregamente abandonam o verso, com suas andanças, seu corte, sua natureza invencivelmente cultivada, erudita, conceitual, para contactar, apegar-se a um objeto bruto, a uma experiência que ainda está para cá dos conceitos, para cá do inevitável encadeamento lógico-associativo, especulativo-psicológico". ${ }^{26}$

Essa aproximação entre poetas e pintores parece bastante nítida na I Exposição Nacional de Arte Concreta, mas deve-se lembrar que, antes de a poesia

\footnotetext{
25 Entre os participantes dessa exposição estavam os artistas plásticos Geraldo de Barros, Waldemar Cordeiro, Lygia Clark, Hélio Oiticica, Alfredo Volpi, Maurício Nogueira Lima, Lygia Pape, entre outros, e os poetas Ronaldo de Azeredo, Augusto e Haroldo de Campos, Décio Pignatari, Ferreira Gullar e Wlademir Dias Pino. Cf. Arquitetura e Decoração, n.20, nov./dez. 1956 (especial sobre a I Exposição Nacional de Arte Concreta).

26 "Poeta \& pintor concretista". In: AMARAL, Aracy A. (org.). Projeto construtivo brasileiro na arte: 19501962. Rio de Janeiro/São Paulo, Museu de Arte Moderna/Pinacoteca do Estado, 1977, p.145.
} 
concreta ser lançada oficialmente, já havia um estreito diálogo dos poetas Augusto e Haroldo de Campos, Décio Pignatari e Ferreira Gullar com os principais grupos representantes da arte concreta, Ruptura (São Paulo) e Frente (Rio de Janeiro), criados em 1952. Mais tarde, esses grupos formam o par concretismo/neoconcretismo. Nesse mesmo ano, Décio Pignatari forma o grupo Noigandres, com Augusto e Haroldo de Campos, e entra em contato com Waldemar Cordeiro (principal expoente do grupo Ruptura). Ferreira Gullar inicia uma longa amizade com o crítico de arte Mário Pedrosa, principal teórico e divulgador da arte abstrata no Brasil. Tanto Gullar quanto Mário Pedrosa e Waldemar Cordeiro, como críticos da época, imprimem diferentes direções ao movimento artístico de vanguarda.

Vale destacar aqui o papel de Mário Pedrosa: na coluna diária "Artes Plásticas", do Correio da Manhã, o crítico trazia o exemplo da arte internacional, especialmente a abstrata, encorajando os jovens artistas brasileiros interessados em romper com os "mestres". Tornou-se um "arauto" das vanguardas artísticas brasileiras, como ele mesmo dizia, em busca da atualização da arte moderna no Brasil:

\begin{abstract}
Na linha da conclusão do Manifesto de Trotsky, Breton e Rivera, acreditava que independência da arte e revolução andavam juntas, batalhando para que o Brasil saísse do isolamento e se alinhasse à arte mais avançada do tempo. Não há dúvida que esbarrava nos impasses característicos de um país periférico, onde falar de independência artística é algo no mínimo problemático, mas o sopro de ar novo que trouxe obrigou nossos artistas e críticos a porem em discussão o rumo que a arte - em nítido refluxo em relação às conquistas vanguardistas - ia tomando entre nós. ${ }^{27}$
\end{abstract}

A arte abstrata, em oposição à arte figurativa, promoverá a autonomia entre arte e representação. Essa autonomia, já preparada pelas vanguardas modernas desde as últimas décadas do século XIX, será questão fundamental nas artes a partir das primeiras aquarelas abstratas de Kandinsky, em 1910. Mais tarde, na década de

\footnotetext{
${ }^{27}$ Cf. ARANTES, Otília Beatriz Fiori. "O ponto de vista do crítico". In: Mário Pedrosa: itinerário crítico. São Paulo, Página Aberta, 1991, p.XII-XIII.
} 
1950, nomes como Malevitch, Calder, Mondrian, Pevsner, Van Doesburg, Walter Gropius, Max Bill e a Escola de Ulm e suas teorias passam a ser divulgados no Brasil, ora por meio de artigos publicados nos principais jornais de São Paulo e do Rio de Janeiro, ora por intermédio de exposições e bienais e dos próprios artistas plásticos brasileiros (caso de Mary Vieira e Almir Mavignier), que promoveram um intercâmbio cultural com o exterior, estudando e expondo nos grandes centros: Alemanha (Escola de Ulm), Suíça e França. Segundo Ferreira Gullar, foi a partir da I Bienal de São Paulo, em 1951, com a participação de Max Bill, que os jovens artistas se entregaram às experiências no campo da linguagem geométrica. ${ }^{28}$

Ronaldo Brito, porém, observa que "a formação mais ou menos simultânea, no campo das chamadas artes visuais, de uma vanguarda de linguagem geométrica no Rio de Janeiro e em São Paulo, no início dos anos 50, obedecia a razões sem dúvida mais significativas do que simplesmente o entusiasmo por recentes exposições de Max Bill, Calder ou Mondrian. O que contou foram as pressões estruturais que os nossos artistas e intelectuais, como membros de classe média, sofreram nesse sentido. Qualquer projeto de vanguarda é sempre um esforço para compreender e evoluir com uma situação". ${ }^{29}$

Enquanto nesse mesmo período o informalismo começava a predominar na Europa e nos Estados Unidos, o Brasil e a Argentina retomavam a tradição construtiva como projeto de vanguarda. Malevitch, Mondrian e Max Bill, que lançaram seus manifestos e movimentos (Suprematismo, "De Stijl” e Arte Concreta, respectivamente) nas primeiras décadas do século $\mathrm{XX}$, só foram assimilados pelas artes plásticas brasileiras na década de 1950. Deve-se lembrar, porém, que essa tradição construtiva tinha na Arte concreta, lançada por Max Bill em 1936, sua principal representante internacional e a última das formulações construtivas importantes da primeira metade do século. Ronaldo Brito lembra que a arte concreta de Max Bill "pretendia operar duas transformações/continuações básicas: a incorporação radical de processos matemáticos à produção artística - levando às

\footnotetext{
28 “Arte concreta". In: Projeto construtivo brasileiro na arte, cit., p.107.

29 "Vanguardas construtivas no Brasil". In: Neoconcretismo: vértice e ruptura do projeto construtivo brasileiro. Rio de Janeiro, Funarte/ Instituto Nacional de Belas Artes, 1985, p.30.
} 
últimas conseqüências as idéias de um Vantongerloo, por exemplo - e o estabelecimento, com suportes mais firmes, do projeto construtivo de integração da arte na sociedade industrial, resultando na abertura da Escola de Ulm (Escola Superior da Forma) em 1951".30

No Brasil, desde a década de 1930, as ideologias construtivas foram introduzidas e primeiro assimiladas pela moderna arquitetura brasileira que precedeu o concretismo e o neoconcretismo. Antes da Escola de Ulm, a Bauhaus, em 1919, já apresentava o racionalismo formalista como uma de suas principais correntes e evidenciava a necessidade de inserir a arquitetura num íntimo diálogo com a sociedade e com a nova orientação técnico-industrial. A idéia de Walter Gropius era desenvolver uma arquitetura "social", que conjugasse as necessidades do indivíduo com as da coletividade; daí o caráter funcional ser o lema da nova arquitetura, em que a idéia era unir o útil ao belo.

Seguindo as idéias da Bauhaus, Le Corbusier, um dos principais ícones da arquitetura moderna, tornou-se o mestre dos grandes arquitetos brasileiros - entre eles Lúcio Costa e Oscar Niemeyer. O demasiado abstracionismo programático estava na base das teorizações de Le Corbusier. Outra idéia do arquiteto era a de realizar a synthèse des arts majeurs, ou seja, reunir as três artes visuais (pintura, escultura e arquitetura) na elaboração de um projeto com a intervenção de diversos artistas. Essas e outras idéias passam a ser divulgadas pelo próprio Le Corbusier, em sua visita ao Brasil em 1929, em conferências no Rio e em São Paulo. Dez anos depois, Le Corbusier realizou no Rio o que chamou de "síntese das artes": iniciou a construção do prédio do Ministério de Educação e Cultura em parceria com Lúcio Costa, Oscar Niemeyer e outros arquitetos, integrando à construção o paisagismo de Burle Marx, a pintura de Portinari e a escultura de Bruno Giorgi.

No Brasil, a adesão às idéias da Nova Arquitetura ocorreu imediatamente. Sob a direção de Lúcio Costa, alguns jovens arquitetos, insatisfeitos com o ensino acadêmico oficial, passam a estudar as obras de Gropius e principalmente as de Le Corbusier. Segundo Mário Pedrosa, “a inspiração doutrinária do grupo - Lúcio

\footnotetext{
${ }^{30}$ Idem, p.33.
} 
Costa, Oscar Niemeyer, Carlos Leão, Jorge Moreira, Afonso Reidy e Ernani Vasconcellos - vinha das idéias de Le Corbusier. Seu dogmatismo teórico de então se alicerçava em um sentimento muito moderno: a fé nas virtualidades democráticas da produção em massa. Esta disciplina teórica lhes permitiu, quando se apresentou a oportunidade, pôr em prática suas idéias". 31

A prática quase imediata das idéias revolucionárias de Le Corbusier no Brasil de 1930 era, no mínimo, paradoxal. Num país de passado colonial, atrasado, situado nos confins da expansão capitalista, em que quase tudo veio de fora, tanto o escravo como o senhor, o importante era criar algo novo, voltar-se para o futuro, modernizar-se. A oficialização progressiva dessa arquitetura, que revelava o gosto pelo suntuoso e pela riqueza, impressionava os responsáveis pela ditadura, que a apoiava como uma forma de autopropaganda e exibição de força dos governantes. Por um lado, essa arquitetura permitiu uma aparente "modernização" brasileira, ainda que forçada e imposta às populações brasileiras que permaneceram exteriores aos projetos dessa modernização, só participando deles como massa de manobras populistas, ou seja, como população subordinada e explorada, excluída por definição das grandes questões da arte. Por outro, permitiu aos jovens artistas realizar os "ideais democráticos e sociais implícitos nos princípios racionais e funcionalistas" do Movimento Moderno. ${ }^{32}$

Algo semelhante pode-se notar durante a década de 1950 com o governo Juscelino Kubitschek e a construção de Brasília. O desenvolvimentismo, modelo econômico adotado por Kubitschek que foi articulado a um certo nacionalismo, no fundo nem era nacionalista nem criava um desenvolvimento capitalista, pois o desejo de fazer o país crescer de forma extraordinariamente rápida obrigou o presidente a apelar maciçamente ao capital estrangeiro e aos empréstimos externos, aumentando a dívida externa. Desse modo, o nacionalismo foi estranhíssimo, baseado no capital estrangeiro e na tecnologia importada. Pode-se dizer que, no plano econômico, houve mais crescimento do que desenvolvimento.

\footnotetext{
31 “Introdução à arquitetura brasileira". In: PEDROSA, Mário. Acadêmicos e modernos: textos escolhidos III. São Paulo, Edusp, 1998, p.386.

${ }^{32}$ Citação de Mário Pedrosa por Otília Arantes, in Mário Pedrosa: itinerário crítico, cit., p.86.
} 
É importante destacar, no entanto, que a ideologia desenvolvimentista, segundo Maria Victoria Benevides, "tinha sobre o nacionalismo vantagens que o tornaram mais atraente, tanto do ponto de vista puramente ideológico, quanto em termos pragmáticos. (...) Isso porque: para a burguesia industrial em expansão o desenvolvimentismo, ao contrário do nacionalismo getulista, evitava a ênfase na intervenção estatal na economia; para a classe trabalhadora, se o nacionalismo era uma abstração, o desenvolvimentismo era concreto: a classe é mobilizada através do exercício do trabalho pela crença num futuro melhor pelos frutos do desenvolvimento (...)".33

A tentativa de realizar na prática a ideologia nacionalista-desenvolvimentista ocorreu com a elaboração e execução do Plano de Metas, um plano de ação econômica em grande escala que apresentou maiores resultados nos setores de energia, indústria, transportes e quase nenhum resultado significativo na educação e no setor agrícola. No entanto, a meta-símbolo do governo foi a construção de Brasília. A nova capital pareceu repetir, só que em grandes proporções, a modernização forçada vista nos anos 1930 com a prática da Nova Arquitetura de Le Corbusier. Projetada em 1956 por Lúcio Costa (que apresentou seu plano-piloto da nova cidade), Brasília sintetizaria as duas ideologias presentes nessa época: o desenvolvimentismo e o projeto construtivo. No ensaio "Reflexões em torno da nova capital", Mário Pedrosa, recorrendo ao conceito de Worringer de "civilizaçãooásis", observa que Brasília seria mais um transplante artificial, entre vários que ocorreram durante o processo de colonização:

Não é paradoxal destinar-se tal "colônia" de fabricação ultramoderna a ser a cabeça dirigente do país, a sede de seu governo? Instalar-se-ia assim o centro políticoadministrativo do Brasil de novo num oásis, isto é, numa colônia de ocupação afastada das áreas onde se desenvolve o processo vital de crescente identificação entre sua história "natural" e sua história cultural e política.

\footnotetext{
33 Entre as vantagens elencadas pela autora, citaram-se algumas. Cf. "O papel da ideologia desenvolvimentista". In: O governo Kubitschek: desenvolvimento econômico e estabilidade política (19561961). Rio de Janeiro, Paz e Terra, 1979, p.240.
} 
Fatalmente isolado do povo brasileiro, o seu governo desconhecerá, não participará senão de fora do drama de seu crescimento, do amadurecimento de sua cultura, da formação de sua personalidade. Brasília seria uma espécie de casamata impermeável aos ruídos externos, aos choques de opinião (...)

Eis por que o programa de Brasília, no seu imediatismo, tem algo de imaturo e, ao mesmo tempo, de anacrônico. ${ }^{34}$

A citação é longa, mas revela os velhos problemas da modernização conservadora: de um lado, as camadas dominantes ultramodernas; de outro, a multidão de despossuídos. Enfim, era esperado que a noção de "desenvolvimento" veiculada pela propaganda presidencial não pudesse ocultar que os êxitos conseguidos com o Plano de Metas e a industrialização forçada estavam associados ao aumento das desigualdades sociais, das disparidades regionais e dos bolsões de miséria. $^{35}$

Enquanto Brasília representou a construção maior, coletiva, funcional e, por isso mesmo, uma obra de arte total, uma "síntese das artes", como pensou Mário Pedrosa, por ser "o exemplo mais completo e oxalá o mais feliz de uma totalidade social, cultural e artística que contém em si mesma", 36 São Paulo, nesse tempo, já concentrava boa parte das indústrias brasileiras e tornou o país um pouco mais moderno.

Pode-se dizer que em 1956 havia um clima favorável ao surgimento da I Exposição Nacional de Arte Concreta no MAM de São Paulo, com a infiltração das ideologias construtivas (Max Bill, Le Corbusier, Niemeyer) e da ideologia desenvolvimentista (governo Kubitschek). Nas artes plásticas foi um momento de reestruturar as linguagens, de atualizá-las com o mundo internacional das artes visuais. Passou-se do campo da criação para o da invenção das formas, rompendo os esquemas convencionais de percepção e de sintaxe. "Frente ao esquema tradicional,

\footnotetext{
${ }^{34}$ In: Acadêmicos e modernos: textos escolhidos III, cit., p.391-392.

${ }^{35}$ Cf. MARANHÃO, Ricardo. "O Plano de Metas e o grande capital". In: O governo Juscelino Kubistchek. São Paulo, Brasiliense, 1994, p.66-67.

${ }^{36}$ Citado por Otília Arantes, in "Brasília: síntese das artes" (Mário Pedrosa: itinerário crítico, cit., p.130).
} 
a arte concreta coloca-se de modo análogo ao da poesia concreta diante do "velho alicerce formal e silogístico-discursivo' da poética convencional e discursiva. Em ambos os casos, a questão é romper um esquema formal dominante e todo o sistema de significações dele necessariamente solidário."37

A arte concreta surge como proposta de radicalização do método construtivo no interior das linguagens geométricas. O concretismo brasileiro elimina o puro intuicionismo, a transcendência e, operando com uma racionalidade estética, propõe o artista informador. Há uma ânsia de superar o atraso tecnológico e o irracionalismo decorrente do subdesenvolvimento.

A poesia concreta, em estreito convívio com a arte concreta, torna-se também uma vertente do projeto construtivo. Pode-se, por exemplo, comparar o plano-piloto da poesia concreta com o de Brasília: o esforço de produzir uma obra de arte total, ultramoderna, funcional, artificial, com o rigor matemático da nova arquitetura de Lúcio Costa e Niemeyer, trazida por Le Corbusier, e a produção esquemática da poesia concreta com sua valorização do espaço. O símbolo do poder e da autoridade representado por Brasília, sede do governo, corresponde ao discurso autoritário e dogmático presente nos manifestos de Augusto e Haroldo de Campos e Décio Pignatari. Uma vista aérea da nova capital, com sua organização planejada e calculada dos prédios nos espaços, já faria lembrar um poema concreto, com suas palavras rigorosamente distribuídas no papel em branco.

Acusados pelos seus "opositores", os poetas e artistas concretos do Rio, de adotarem um racionalismo excessivo e ignorarem os problemas sociais, os poetas concretos de São Paulo procuraram fazer do concretismo uma imitação do modelo nacionalista-desenvolvimentista de Kubitschek: no plano político-econômico, o capital estrangeiro financiava o "desenvolvimento" do país; no plano artístico, a importação de modelos como Max Bill, Le Corbusier, Mondrian, Norbert Wiener, Gestalt etc. desempenhava o mesmo papel. Isso também não deixava de ser uma retomada da teoria antropofágica de Oswald de Andrade, como observou Ronaldo Brito:

\footnotetext{
${ }^{37}$ Cf. BRITO, Ronaldo. Neoconcretismo: vértice e ruptura do projeto construtivo brasileiro, cit., p.36.
} 
Mas é fácil perceber igualmente que, com sua afirmação dos valores da modernidade, e com sua progressista recusa de assumir uma mítica nacionalista, essa produção nem por isso dissimulava uma defasagem cultural tipicamente subdesenvolvida: ela parecia ignorar as verdadeiras condições sociais em que emergia e dizia bem menos respeito à nossa realidade cultural mais ampla do que às afetações e pretensões de um grupo vanguardista de classe média. Apesar de lances importantes como a retomada de Oswald de Andrade e sua teoria antropofágica; apesar da proposta de criação de um "barroco industrial", atendendo às disposições específicas da realidade brasileira, o Concretismo não foi capaz de pensar sistematicamente a razão política de sua prática e justificar a sua inserção no nosso ambiente cultural. ${ }^{38}$

Deve-se lembrar, entretanto, que em 1959 o concretismo carioca assume oficialmente uma posição contrária à dos artistas concretos paulistas: se os últimos estão preocupados com a industrialização, os mass media, as teorias racionalistas, os processos semióticos, o primeiro, já definido nesse momento como neoconcretismo, como "vértice e ruptura da tradição construtiva brasileira", na expressão de Ronaldo Brito, rejeita o racionalismo, retoma elementos da ideologia romântica e assume uma concepção empirista do trabalho de arte, suas significações sociais e humanas. É importante ressaltar que as características apresentadas até agora do concretismo e o neoconcretismo, principalmente no campo das artes plásticas, vão se refletir na poesia também.

Outra diferença observada entre os dois movimentos nas artes plásticas é o uso da cor. Enquanto o paulista Waldemar Cordeiro defende o uso "intelectual" do branco/preto, os artistas cariocas defendem o uso "emocional" da cor. Essa posição é análoga na poesia: os poetas concretos dispõem de uma aplicação racional da palavra que é reduzida a um objeto-coisa; os poetas neoconcretos imprimem à palavra um uso vivencial, orgânico.

Enquanto o concretismo e o neoconcretismo (nas artes plásticas e na poesia), com suas teorias e práticas, provocaram polêmica no campo das artes nos anos 1950, a década seguinte deu novos rumos a essas vanguardas. A euforia provocada

\footnotetext{
${ }^{38}$ Idem, p.44.
} 
com a industrialização e certa "prosperidade" durante o governo Juscelino Kubitschek (1956-1960) não se estendeu aos anos 1960. A industrialização era destinada a um mercado restrito e de alto poder aquisitivo (representado por uma burguesia nacional e multinacional), o que provocou uma acentuada concentração de renda, baixos salários, desequilíbrios regionais, enfim, sérios problemas que impulsionaram a classe trabalhadora urbana e rural à formação de movimentos reivindicatórios com feições políticas no início da década de 1960. Nesse momento, a Doutrina de Segurança Nacional, elaborada na década anterior pela Escola Superior de Guerra, “tornou-se um ponto de convergência ideológica e a ESG um ponto de encontro entre setores militares e os novos setores burgueses; grupos que aprofundaram e acirraram internamente a polarização esquerda versus direita que funcionou como estratégia para desalojar do poder os grupos populistas". 39

Num sentido inverso ao do governo Kubitschek, João Goulart procurou estimular a indústria e os setores agrários produtores de bens básicos para o mercado interno, reduzir as desigualdades regionais e o analfabetismo e controlar a inflação. A proposta nacional-reformista de Goulart era vista pela esquerda como a realização de uma das etapas da "revolução". Ao mesmo tempo em que apoiava o governo, pressionava-o para ver as promessas cumpridas.

É importante destacar que houve uma intensa mobilização social nesse período, como aquela da UNE (União Nacional dos Estudantes) que assume uma posição social, a qual teve um desempenho importante na área da cultura popular com o CPC (Centro Popular de Cultura), criado em 1961. Esse movimento, em oposição às vanguardas artísticas "formalistas" dos anos 1950, atuou em várias partes do país, promovendo atividades literárias, musicais, teatrais e plásticas. Preocupando-se com o lugar social do artista, que deveria assumir uma "missão salvadora", o CPC voltou-se para as temáticas populares que funcionavam como propaganda política; logo, negava qualquer experimentação na linha do concretismo ou do neoconcretismo.

\footnotetext{
${ }^{39}$ Cf. PAES, Maria Helena Simões. A década de 60: rebeldia, contestação e repressão política. São Paulo, Ática, 1997, p.33-34.
} 
Pode-se dizer que, enquanto nos anos 1950 as artes vanguardistas seguem, preponderantemente, o caminho da "construção", da internacionalização, no início da década seguinte muitos artistas de esquerda voltam-se para a participação, o nacional, o popular. Algumas vanguardas "formalistas", como o concretismo, especialmente a poesia concreta, tentam adaptar-se à nova situação, produzindo alguns poucos textos teóricos e poemas que esbarram na questão nacional e social. Sentindo-se impossibilitado de fazer uma vanguarda essencialmente formalista, Ferreira Gullar deixa o neoconcretismo em 1961 e alia-se ao CPC.

Dissolvido o neoconcretismo, como movimento organizado, dotado de propostas teóricas, o comportamento experimental continuou presente nas manifestações de vanguarda posteriores, como a Instauração Praxis, de Mário Chamie, que vai "tomar lugar" do movimento neoconcreto nas polêmicas com o concretismo e os seus principais inventores. Praxis, movimento que se manifesta principalmente na literatura, ainda na linha "formalista", tenta integrar a experimentação formal com a participação, como um meio-termo entre concretismo e CPC.

Mas o que era puro espírito de renovação nos anos 1950, com as poesias concreta e neoconcreta, era na década seguinte o impasse maior de criar uma poesia moderna participante, que estivesse atualizada não somente com a industrialização, mas também com as questões sociais:

Da comparação, embora aproximativa, derivaria a impressão de que os anos 50 caracterizavam-se pela montagem (ou, no mínimo, reforço) de tendências ideológicas nacionalistas que vinham se plasmando em ressonância a processos políticos e sociais marcados pelo desenvolvimento econômico e pela criação de condições para uma possível revolução burguesa. A superação do subdesenvolvimento - o termo ganhou concreção nessa década - transformou-se em alvo difuso a ser atingido pelas "forças vivas da Nação": de "periferia" dever-se-ia atingir, de maneira planejada, a condição de "centro", para retomar vocabulário caro aos nacionalistas. Nos anos 60 , sobretudo na segunda metade, o que se verifica é a inviabilidade da fórmula, ocorrendo críticas e revisões radicais. Observadas em conjunto as duas décadas, dir-se-ia que a primeira é de consolidação de um sistema ideológico (com suas múltiplas vertentes, por vezes, diretamente, interligadas: 
neocapitalista, liberal, nacionalista, sindicalista, desenvolvimentista, marxista); ao passo que a segunda década, vista globalmente, aparece antes como de desintegração desse sistema ideológico, apresentando vertentes em que houve rupturas radicais, dando origem a novas constelações de difícil avaliação (...). ${ }^{40}$

Se na visão global de Carlos Guilherme Mota a década de 1960 apresentou uma desintegração do sistema ideológico visto na década anterior, especificamente no plano dos movimentos de vanguarda poética, a presença da questão nacional "é fundamental para se equacionar uma perspectiva que viabilize a criação de um futuro. Muitas vezes, a discussão entre os poetas concretistas e os setores ditos nacionalistas é apresentada como se os primeiros fossem realmente os críticos da questão nacional, abraçando a causa da internacionalização. Esquece-se, porém, que a própria idéia de 'vanguarda construtiva e planificada' encerra em si a noção de projeto, no sentido de planificação que antecede todo um movimento cultural: como este Plano Piloto da Poesia de Décio Pignatari, que nos lembra tanto as exigências da época, a construção de Brasília e seu Plano Piloto". ${ }^{41}$

Por fim, em 1967, em plena ditadura militar e já um pouco fora de situação e com pouco fôlego, surge o poema-processo que, se por um lado, radicaliza as principais idéias da poesia concreta, por outro, retoma muitas experimentações do cubismo e do futurismo.

\subsubsection{Vanguardas poéticas e situação literária}

No campo literário, em 1950, a chamada "geração de 45" era representante do academicismo artístico, com suas recuperações neoparnasianas e neosimbolistas. Em oposição ao arcaísmo dessa geração, a poesia concreta surgiu como representante do industrialismo, do desenvolvimentismo. Se, por um lado, a poesia

\footnotetext{
${ }^{40}$ Cf. MOTA, Carlos Guilherme. "Nacionalismo, desenvolvimento, radicalismo: novas linhas da produção cultural”. In: Ideologia da cultura brasileira (1933-1974). São Paulo, Ática, 1980, p.155-156.

${ }^{41}$ Cf. ORTIZ, Renato. A moderna tradição brasileira. São Paulo, Brasiliense, 1988, p.109.
} 
concreta rompeu com os poetas de 1945, por outro, fez de João Cabral de Melo Neto uma das referências para suas invenções. Na linhagem de Murilo Mendes e Carlos Drummond de Andrade, João Cabral produziu uma linguagem direta, objetiva, econômica, "antilírica", algumas vezes geométrica, características que levaram o nome do poeta para o elenco do paideuma concreto. Essas renovações, no entanto, não eram suficientes para a produção de uma nova poesia. Foi preciso atualizar-se com o que estava ainda iniciando no Brasil: os mass media, as noções da cibernética e da teoria da informação, a propaganda, a indústria, o objeto de consumo.

Para Antonio Candido, uma das fontes da poesia de vanguarda brasileira da segunda metade do século XX é o modernismo dos anos 1920, com a "estética do fragmento, as intenções antilíricas e um certo gosto pela desarticulação do poema. Com isto, instauraram um ar de jogo combinatório, de experiência calculada e de projeto mental que contrastava com a expressão dominante no decênio de 50 , a da chamada 'geração de 45', formada por poetas inclinados ao mistério, ao sentimentalismo, a um certo patético, embora entre eles se inclua um completamente diferente, João Cabral de Melo Neto, precursor da vanguarda atual". ${ }^{42}$ Mas ressalta:

Estas tendências, seguidas por poetas que são quase todos também críticos, são cheias de interesse e de ânimo renovador; mas podem comprometer a poesia e, implicitamente, a própria concepção de literatura. Lendo-os, sentimos às vezes como pode ficar tênue, quase impalpável, a fronteira entre poesia e piada, trocadilho, jogo gratuito, associação livre, charada, caricatura, propaganda, representação visual. ${ }^{43}$

Antonio Candido declara ainda que, mesmo reservadas as diferenças entre as experiências poéticas do concretismo, neoconcretismo, praxis e outras tendências:

Forçando bastante, seria possível tentar caracterizar estas correntes, por vezes inimigas entre si, pelo seguinte resumo: supressão dos nexos sintáticos e conseqüente

\footnotetext{
${ }^{42}$ CANDIDO, Antonio.“A literatura brasileira em 1972”. Arte em Revista, ano 1, n.1, p. 22, jan./mar. 1979.

${ }^{43}$ Idem, p. 22.
} 
descontinuidade do discurso: substituição da ordem temporal, não linear: substituição da metáfora pela paronomásia. ${ }^{44}$

Em João Cabral de Melo Neto, a preocupação de produzir uma poesia atualizada com a época é apontada na tese apresentada ao Congresso de Poesia de São Paulo, em 1954, ${ }^{45}$ que defende a idéia de que a crise da poesia em nosso tempo decorre, principalmente, do desajuste da forma moderna e individualista do poema aos meios de comunicação próprios da época.

A tese de João Cabral parece prever o que será apresentado oficialmente em 1956 pelo grupo Noigandres, o mesmo criador da poesia concreta: uma poesia que rompe com a geração individualista de 45 , com o verso, valorizando as novas técnicas jornalísticas, a teoria da informação, a cibernética, a segunda revolução industrial etc.

É interessante notar que a poesia concreta, efetivamente a que mais teve atuação e alguma eficácia prática, previa nos seus manifestos e textos críticos uma técnica do escândalo, ou seja, a intervenção nos circuitos letrados da crítica literária, principalmente, desqualificando modos de conceber e fazer "poesia" e, para isso, afirmando os autores vanguardistas como arautos do novo, os "primitivos de uma nova era". Há no discurso da teoria da poesia concreta um "eu" autoral que é imperial, pleno de certeza, autoritário e mitológico, principalmente pela disseminação de nomes de filósofos, artistas, semióticos, lingüistas etc. agrupados por justaposição, o que apaga justamente a particularidade histórico-ideológica de cada um dos sistemas teóricos ou regimes artísticos que são citados.

Isso produzia, por um lado, o que Wilson Martins definiu muito bem:

O paradoxo da poesia moderna (digamos, do Modernismo ao Concretismo) está em que a sua importância independe e transcende de seu eventual sucesso estético. Quero dizer com isso que, realizando-se, em grande parte, por meio de obras falhadas ou discutíveis, ela criou uma "situação literária" depois da qual a poesia nunca mais seria a mesma (...). ${ }^{46}$

\footnotetext{
${ }^{44}$ Idem, ibidem.

45 “Da função moderna da poesia". In: Obra completa. Rio de Janeiro, Nova Aguilar, 1995, p.767.

46 “Destinos da poesia”. O Estado de S. Paulo, 18 jun. 1966. Suplemento Literário, p.2.
} 
No papel de críticos, os poetas concretos Augusto e Haroldo de Campos e Décio Pignatari renovavam as referências, obrigando os interessados em arte a pensar em novas possibilidades teóricas. Também usavam os nomes dos autores com a preocupação de demonstrar um saber que os fazia melhores, como se ninguém os conhecesse.

Ao observar os textos críticos, nota-se que a poesia concreta incidia criticamente em vários pontos fundamentais, que devem ser destacados: a) o da prática e consumo de poesia escrita com verso, metrificado ou livre; b) o da crítica contemporânea de poesia, adepta ou não da poesia moderna ou modernista; c) o da historiografia literária e da luta pela autoridade canônica, ou seja, a disputa pelo poder de determinar quem é quem na literatura e também determinar de que modo deve ser lida.

Quanto à poesia, os poetas concretos decretavam o encerramento do ciclo histórico do verso. Essa afirmação postula um desenvolvimento retilíneo e evolutivo das artes, pressupondo que elas se superam no tempo. O próprio pressuposto é discutível, pois afirma uma teleologia, um finalismo ou um ponto do futuro ainda não realizado, mas de onde vem o sentido dessa superação, sem suficiente base teórica e principalmente empírica. Ainda sobre a poesia, ao mesmo tempo em que declaram o encerramento do ciclo histórico do verso, os concretos propõem noções como "não-linear", "descontínuo", "simultâneo", "espaço", que são transpostas das artes plásticas, da matemática e da teoria da informação.

No caso da crítica, é importante observar que, nos anos 1950, havia, principalmente nos suplementos literários, pelo menos três correntes: o velho impressionismo baseado nas livres associações psicológicas dos intérpretes, como Sérgio Milliet; a crítica sociológica do grupo de Antonio Candido, da revista Clima, dos anos 1940; e um início de new criticism norte-americano, trazido para o Brasil principalmente por Afrânio Coutinho. O núcleo de todas essas críticas era a representação, que não era posta em questão, pois a literatura era lida como expressão do drama humano ou como reflexo de contradições sociais. O new criticism propunha a análise imanente das formas literárias e as questões de técnica 
do verso ou técnica narrativa. Enfim, nada de "novo", no sentido vanguardista. "A nova crítica era para a crítica o que a poesia concretista estava sendo, no mesmo momento, para a poesia, isto é, uma teoria brilhante com demonstrações decepcionantes no campo das aplicações práticas, onde o pluralismo metodológico aparecia como um contraponto sugestivo., ${ }^{47}$

Por último, a questão da história literária e do cânone. Os poetas concretos inventam sua tradição do novo, por isso descartam tudo que não interessa ao seu presente de produção. No caso, com um enunciado escandalosamente nacionalista "arte de exportação" - os concretistas propunham o internacionalismo em arte que era o up-to-date da desconstrução em poesia: Mallarmé (mas não Rimbaud), Pound (mas não T. S. Eliot) e Joyce (mas não Kafka ou Proust). A escolha de autores nitidamente anti-realistas, que deram importância às questões formais, também indica a oposição ao modelo de história literária ainda dominante, que vem do romantismo, que entende a literatura como representação da cultura nacional e pressupõe, para isso, a expressão, a representação, o realismo, a realidade nacional etc.

Vistos assim, os poetas concretos, além de promoverem uma nova situação literária e um domínio dessa situação sobre as demais vanguardas poéticas (tiveram a vantagem de inaugurar o segundo ciclo vanguardista no contexto da modernidade literária brasileira), também expressaram a possibilidade de modernização e progresso tecnológico e industrial, atualizando suas experimentações formais com as pesquisas mais recentes da tecnologia e da ciência.

Mesmo coincidindo com as idéias de modernização e com a promessa de futuro melhor, divulgadas pela política econômica do governo Kubitschek, os textos teóricos e programáticos do grupo concreto, até o final dos anos 1950, não fazem referências à circunstância histórica imediata, mas direcionam-se para o culto excessivo dos avanços e grandes conquistas científicas e tecnológicas ainda tão distantes do cenário cultural brasileiro. ${ }^{48}$

\footnotetext{
${ }^{47}$ Cf. MARTINS, Wilson. A crítica literária no Brasil (1940-1981). Rio de Janeiro, Francisco Alves, 1983, v.II.

${ }^{48}$ Cf. SIMON, Iumna Maria, art. cit., p. 342.
} 
Não há como negar a posição privilegiada e decisiva do grupo Noigandres no sistema literário, como observaram vários críticos. ${ }^{49} \mathrm{~A}$ atuação do grupo instaurou um paradigma para a poesia contemporânea. Contrariando a própria noção de vanguarda estética, que rompe com os cânones, inaugura uma nova tradição no Brasil, a da poesia visual. ${ }^{50}$

De acordo com Iumna Maria Simon, o modelo instaurado pelos poetas concretos, que serviu de matriz para os demais movimentos, pressupõe uma produção que trabalhe com as seguintes questões: a consciência utilitária; a abertura da poesia à cultura dos meios de comunicação; a mudança do espaço de fruição do poema; a mudança da relação sujeito/objeto; a necessidade de construir um "paideuma"; a concepção de uma historiografia própria, na qual se inclui a revisão da literatura brasileira, com base na eficiência de certos procedimentos; a crise do verso; e a antidiscursividade. ${ }^{51}$

Se o grupo Noigandres exerceu um papel crítico sobre o sistema literário já ineficaz e desgastado para a nova poesia de vanguarda, neoconcretismo e praxis, se não trouxeram tantas novidades e alcance crítico quanto a poesia concreta, cumpriram bem o papel de críticos dessa vanguarda. O neoconcretismo combate o que ele considera o racionalismo excessivo dos concretistas e pretende devolver à palavra sua "totalidade transcendente", seu valor subjetivo e social. Praxis, já inserida no contexto do nacional-popular dos anos 1960, denomina concretismo e neoconcretismo de "vanguarda velha" que, se parece uma designação contraditória, não deixa de ser verdadeira, pois esses primeiros movimentos, apegados à ideologia construtiva mais presente nos anos 1950, envelheceram diante da nova situação discutida nos anos 1960. Praxis, apesar de se utilizar de muitos procedimentos construtivistas semelhantes aos dos concretos, introduz a noção de área de levantamento, a qual propõe uma valorização de uma situação social que, totalizada,

\footnotetext{
${ }^{49}$ Cf. Wilson Martins (nota 44). Entre os críticos mais recentes estão: Iumna Maria Simon (art. cit.) e Paulo Franchetti (Alguns aspectos da teoria da poesia concreta, Campinas, Editora da Unicamp, 1989).

${ }^{50}$ Cf. MENEZES, Philadelpho. A trajetória visual da poesia de vanguarda brasileira. Dissertação de mestrado apresentada à PUC-SP. São Paulo, 1987, 158p. Seguindo a direção da crítica formalista, o autor faz uma análise semiótica da poesia visual brasileira, partindo da poesia concreta como matriz dos demais movimentos: neoconcretismo e poema-processo.

${ }^{51}$ Art. cit., p.346.
} 
imprime uma tendência participante, como instrumento de transformação da realidade brasileira. Talvez a denominação "vanguarda nova", como se autodenominou praxis, seja um tanto forçada nesse momento em que o próprio termo "vanguarda" já se encontra desgastado.

O poema-processo rompe com a história literária, dispensa a palavra e, em seu lugar, enfatiza a importância dos signos não-verbais. Propõe uma radicalização superficial dos movimentos anteriores: retoma o poema-código ou semiótico da poesia concreta e introduz a idéia de "processo", que promove certo dinamismo ao poema. Com base em um poema-matriz, é proposta a invenção de séries que fazem do leitor um co-autor. Se o poema-processo procurou espantar pela radicalidade, rompendo com o passado, espantou também pela superficialidade ao reintroduzir procedimentos técnicos básicos das vanguardas anteriores: ao propor uma dinâmica nas estruturas, muito próximas da última fase da poesia concreta, retoma também os procedimentos futuristas e cubistas.

Para que se tenha uma noção mais clara das questões levantadas até aqui, na próxima parte desta dissertação é feita uma leitura dos principais textos teóricos e programáticos e são comentados alguns poemas significativos de cada movimento da poesia de vanguarda brasileira. 


\section{DA POESIA CONCRETA AO POEMA-PROCESSO}

Marinetti, Acadêmico

Lá chegam todos, lá chegam todos...

Qualquer dia, salvo, venda, chego eu também...

Se nascem, afinal, todos para isso...

Não tenho remédio senão morrer antes,

Não tenho remédio senão escalar o Grande Muro...

Se fico cá, prendem-me para ser social...

Lá chegam todos, porque nasceram para Isso,

E só se chega ao Isso para que se nasceu...

Lá chegam todos...

Marinetti, acadêmico...

As Musas vingaram-se com focos elétricos, meu velho, Puseram-te por fim na ribalta da cave velha,

E a tua dinâmica, sempre um bocado italiana, f-f-f-f-f-f-f-f...

Álvaro de Campos $(1969,415)$

\subsection{Poesia concreta}

Du sagst nichts und verrätst nichts, o Ulysses, aber Du wirkst.

Carl Gustav Jung

Para traçar a trajetória da poesia concreta, duas fontes são fundamentais: Teoria da poesia concreta (de Augusto e Haroldo de Campos e Décio Pignatari) e Noigandres 5. A primeira reúne os principais artigos (textos críticos e manifestos) que foram publicados em jornais - como Correio Paulistano, Jornal do Brasil, Diário de São Paulo, O Estado de S. Paulo - e revistas - Noigandres e Arquitetura e Decoração - que circularam na época. Já a segunda, último número da revista, é uma antologia do grupo, do verso à poesia concreta. Essas duas fontes, vale ressaltar, permitem uma leitura cronológica do movimento da poesia concreta, na teoria e na prática. 
Trata-se aqui de considerar e analisar os textos teóricos mais expressivos sobre a poesia concreta, bem como os poemas mais significativos, e observar no processo de atualização e transformação do objeto estético seu distanciamento do conceito tradicional de poesia e, paralelamente, as contradições desse processo.

Segundo eles, na ausência de críticos da época adequados para analisarem e discutirem a poesia concreta e os demais movimentos de vanguarda, os próprios poetas concretos tornaram-se críticos de suas obras, como se pode notar em alguns textos teóricos do grupo Noigandres que trazem leituras e comentários sobre os poemas. $^{52}$

$\mathrm{Na}$ "Introdução" da 2a edição de 1975 da Teoria da poesia concreta, Augusto de Campos observou:

(...) Realmente, mais do que a teoria nos interessava ver editada a poesia - sempre menos editável -, a poesia, que é afinal o que interessa. A teoria não passa de um tacape de emergência a que o poeta se vê obrigado a recorrer, ante a incompetência dos críticos, para abrir a cabeça do público (a deles é invulnerável). ${ }^{53}$

Em estudo sobre a teoria da poesia concreta, Paulo Franchetti, ao analisar a trajetória teórica do grupo Noigandres, nota a presença de pelo menos três fases bem distintas: "aquela em que começa a constituir o projeto poético, aquela em que se trata de justificar e defender o projeto e aquela em que se faz mais fraca a coesão do grupo". 54

Franchetti afirma, no entanto, que:

\footnotetext{
${ }^{52}$ É o caso de "Poesia concreta: pequena marcação histórico-formal", que comenta os poemas silêncio, de Haroldo de Campos, o formigueiro, de Ferreira Gullar e ovonovelo, de Augusto de Campos; "Poesia concreta - linguagem - comunicação", de Haroldo de Campos, que trata dos poemas terra e beba coca cola, ambos de Décio Pignatari; "Poesia concreta: organização", que comenta os poemas um movimento, de Décio Pignatari, velocidade, de Ronaldo Azeredo, e outros; "A moeda concreta da fala", que traz comentários sobre hombre hembra - hambre, de Décio Pignatari, e branco - vermelho, de Haroldo de Campos; "Novos Poemas Concretos", que fala sobre caviar, de Décio Pignatari, e forma, de José Lino Grünewald. Todos os artigos foram publicados em Teoria da poesia concreta, organizado por Augusto e Haroldo de Campos e Décio Pignatari (São Paulo, Brasiliense, 1987).

${ }^{53}$ P.11.

${ }^{54}$ Alguns aspectos da teoria da poesia concreta, cit., p.27.
} 
uma pessoa que estivesse preocupada fundamentalmente com a produção poética do grupo Noigandres certamente se sentiria inclinada a encarar a produção teórica de acordo com as várias "fases" poéticas do grupo: a "pré-concreta", a da "fenomenologia da composição", a da "matemática da composição", a do "salto participante" e a dos "poemas semióticos". 55

Como a finalidade desta dissertação é discutir algumas contradições do percurso da poesia de vanguarda brasileira, faz-se necessária uma leitura dos principais textos teóricos de cada movimento e suas práticas correspondentes; portanto, para estabelecer uma relação entre teoria e poesia, a tendência é seguir as fases da produção poética, no caso da poesia concreta.

Tendo em vista primeiro as concepções de poesia concreta, o estudo se inicia com a leitura crítica da teoria, seguindo as fases da poesia. $\mathrm{O}$ texto que abre a Teoria da poesia concreta é um depoimento de Décio Pignatari, de 1950, que tenta descrever como deve ser a nova poesia:

Um poema não quer dizer isto nem aquilo, mas diz-se a si próprio, é idêntico a si mesmo e à dissemelhança do autor, no sentido do mito conhecido dos mortais que foram amados por deusas imortais e por isso sacrificados. ${ }^{56}$

É fundamental assinalar que essa é uma "definição" de poema que irá persistir nos textos teóricos posteriores.

Em "Poetamenos" (1955), publicado como introdução à série de poemas poetamenos, Augusto de Campos busca uma "melodiadetimbres com palavras". O poeta utiliza diferentes procedimentos (a função das cores como vozes, disposição espacial das palavras, a ruptura sintática, “as palavras são funcionalizadas pela melodia das cores" ${ }^{, 57}$ ):

como em Webern:

uma melodia contínua deslocada de um instrumento para outro, mudando constantemente sua cor:

\footnotetext{
${ }^{55}$ Idem, ibidem.

56 “Depoimento". In: Teoria da poesia concreta, cit., p.15.

${ }^{57}$ Cf. MENEZES, Philadelpho, op. cit., p.13.
} 
instrumentos: frase/palavra/sílaba/letra(s), cujos timbres se definam p/um tema gráfico-fonético ou "ideogrâmico". ${ }^{58}$

É interessante observar que essa citação de Augusto de Campos, ao valorizar o som e o timbre das palavras, sílabas e letras, analogamente, faz lembrar o modelo da fonologia, a qual trabalha com fonemas que, como unidades distintivas de significado, não têm significação em si, mas passam a tê-la quando combinados ou permutados com outros. A disposição dos elementos na página inclui o espaçosuporte como signo, ou seja, o espaço também significa, segundo as aberturas, as linhas, as distâncias etc., como se pode notar no poema a seguir de Augusto de Campos, da série poetamenos:

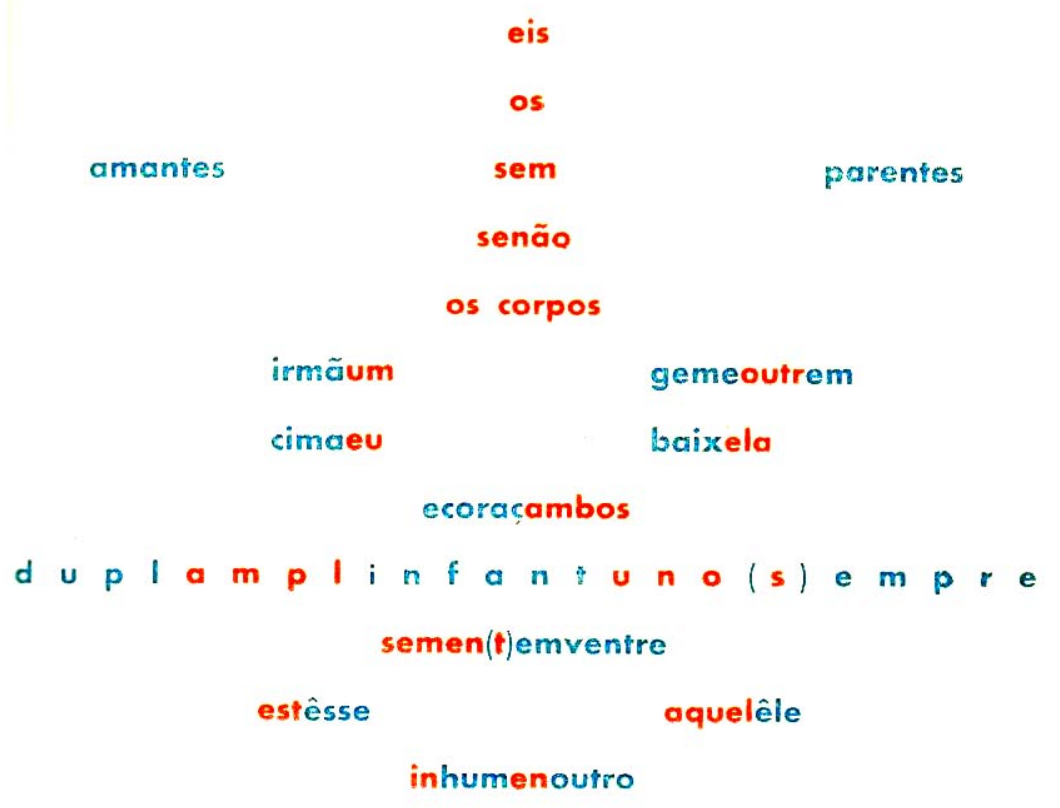

Em "Pontos - periferia - poesia concreta" $(1956),{ }^{59}$ Augusto de Campos cita o termo "poesia concreta" pela primeira vez:

\footnotetext{
${ }^{58}$ Teoria da poesia concreta, cit., p. 21. A série de poemas poetamenos é de janeiro e julho de 1953 e foi publicada originalmente em Noigandres (n. 2, fev. 1955).

59 In: Teoria da poesia concreta, cit., p.23-31. É preciso lembrar que esse artigo constitui a fusão, com ligeiras modificações, dos artigos "Poesia, estrutura" e "Poema, ideograma", publicados em 20 e 27 de março 1955 no Diário de São Paulo.
} 
A verdade é que as "subdivisões prismáticas da Idéia", de Mallarmé, o método ideogrâmico de Pound, a apresentação "verbivocovisual" joyciana e a mímica verbal de Cummings convergem para um novo conceito de composição, para uma nova teoria de forma - uma organoforma - onde noções tradicionais como princípio-meio-fim, silogismo, verso tendem a desaparecer e ser superadas por uma organização poético-gestaltiana, poético-musical, poético-ideogrâmica da estrutura: POESIA CONCRETA. ${ }^{60}$

Augusto de Campos, apesar de ainda não definir com precisão o que será essa "poesia concreta", diante das pesquisas sobre os rumos tomados pela literatura e, principalmente, pela poesia, com Mallarmé, Pound e cummings , observa que os procedimentos adotados por esses poetas apontam para "um novo conceito de composição, para uma nova teoria da forma".

O termo "poesia concreta" novamente aparece em artigo homônimo de Augusto de Campos (1955):

Em sincronização com a terminologia adotada pelas artes visuais e, até certo ponto, pela música de vanguarda (concretismo, música concreta), diria eu que há uma poesia concreta. Concreta no sentido em que, postas de lado as pretensões figurativas da expressão (o que não quer dizer: posto à margem o significado), as palavras nessa poesia atuam como objetos autônomos. Se, no entender de Sartre, a poesia se distingue da prosa pelo fato de que para esta as palavras são signos enquanto para aquela são coisas, aqui essa distinção de ordem genérica se transporta a um estágio mais agudo e literal, eis que os poemas concretos caracterizar-se-iam por uma estruturação ótico-sonora irreversível e funcional, e, por assim dizer, geradora da idéia, criando uma entidade todo-dinâmica, "verbivocovisual" - é o termo de Joyce - de palavras dúcteis, moldáveis, amalgamáveis, à disposição do poema. ${ }^{61}$

O trecho é bastante significativo para a análise. O poeta observa o uso do termo "concreto" nas artes visuais e na música (o concretismo e a música de vanguarda) e, numa tentativa de atualizar-se com os novos movimentos, transfere-o para a poesia que está projetando. Segundo Augusto de Campos, seu uso elimina as "pretensões figurativas", mas não o significado. Eliminada a função de

\footnotetext{
${ }^{60}$ Idem, p. 31 .

${ }^{61}$ Idem, p.40.
} 
representação da palavra, o significado, obscurecido, parece transferido para uma mera "estruturação ótico-sonora irreversível e funcional”. Sendo assim, as palavras "atuam como objetos autônomos". Essa idéia, pode-se dizer, é um desenvolvimento do que foi visto no primeiro texto de Décio Pignatari: o poema "é idêntico a si mesmo".

Da poesia chamada pré-concreta, produzida até 1955, parte ainda apresentada em versos, chamam a atenção os poemas bestiário e a série poetamenos, de Augusto de Campos. Os poemas apresentam uma valorização do espaço, uma fragmentação da palavra e uma preocupação com seu aspecto visual e sonoro.

Com a I Exposição Nacional de Arte Concreta (realizada no MAM, de São Paulo, em dezembro de 1956, e no MAM, do Rio de Janeiro, em fevereiro de 1957), foram publicados alguns manifestos curiosos que vão lançar a nova poesia e problematizar a discussão. Neste momento, vale destacar os textos de Haroldo de Campos e Décio Pignatari, que são os principais dessa fase. Em "Arte concreta: objeto e objetivo" (1956), Décio Pignatari faz um balanço das pesquisas já realizadas e anuncia a "fase polêmica" do grupo:

A poesia concreta, depois de um período mais ou menos longo de pesquisas - para determinar os planos de clivagem de sua mecânica interna (Mallarmé, Un coup de Dés Pound - Joyce - Cummings - algumas experiências dadaístas e futuristas - algumas postulações de Apollinaire) -, entra na sua fase polêmica. A mostra de poesia concreta tem um caráter quase didático: fases da evolução formal, passagem do verso ao ideograma, do ritmo linear ao ritmo espácio-temporal: novas condições para novas estruturações da linguagem, esta relação de elementos verbivocovisuais - como diria Joyce. ${ }^{62}$

E mais adiante:

Abolido o verso, a poesia concreta enfrenta muitos problemas de espaço e tempo (movimento) que são comuns tanto às artes visuais como à arquitetura, sem esquecer a

\footnotetext{
${ }^{62}$ Idem, p.45.
} 
música avançada, eletrônica. Além disso, p. ex., o ideograma, monocromo ou a cores, pode funcionar perfeitamente numa parede, interna ou externa. ${ }^{63}$

Pignatari observa que, eliminado o verso, a poesia concreta pode ser comparada às artes visuais, pois incorpora à sua estrutura o espaço e o tempo. Em artigo posterior, "Nova poesia: concreta" (1956), ao propor o "novo" estético, banaliza-o, pois "desierarquiza" o poético como equivalência geral das linguagens o que equivale a identificar propaganda e poesia, por exemplo, propondo a poesia como mercadoria. Sabe-se que ela é mercadoria, mas com mediações; aqui, tudo se equivale:

uma arte geral da linguagem. propaganda, imprensa, rádio, televisão, cinema. uma arte popular.

a importância do olho na comunicação mais rápida: desde os anúncios luminosos até as histórias em quadrinhos. A necessidade do movimento. A estrutura dinâmica. O ideograma como idéia básica. ${ }^{64}$

Sobre o texto de Pignatari, vale notar ainda que, ao sugerir uma "arte geral" que inclua os mass media e outras linguagens, essa "nova" arte torna-se representável, idéia que o autor parece repelir ao dizer:

a poesia concreta acaba com o símbolo, o mito. com o mistério. o mais lúcido trabalho intelectual para a intuição mais clara. acabar com as alusões. com os formalismos nirvânicos da poesia pura. a beleza ativa, não para a contemplação.

(...) o poema é forma e conteúdo de si mesmo, o poema é. a idéia-emoção faz parte integrante da forma, vice-versa, ritmo: força relacional. ${ }^{65}$

Outra questão do artigo sobre a qual deve-se pensar é o uso da expressão “arte popular", que parece significar "de massa". Pignatari, no artigo, acredita que a poesia concreta, proposta como "arte geral" equivalente aos mass media, possa ser acessível ao grande público. No entanto, o autor não leva em conta as contradições

\footnotetext{
${ }^{63}$ Idem, p.46.

${ }^{64}$ Idem, p.47.

${ }^{65}$ Idem, p.48-49.
} 
das classes sociais nem o momento de uma sociedade de consumo ainda incipiente que só será mais bem definida nos anos 1960 e 1970 como mercado de bens culturais. ${ }^{66}$ Segundo Paulo Franchetti:

Ao que tudo indica, Pignatari fala aqui de "arte popular" para sugerir que a poesia concreta, utilizando procedimentos semelhantes aos usados nos meios de comunicação de massa, estaria mais apta a atingir o público acostumado a esses procedimentos do que a poesia "tradicional" em versos. Assim sendo, um dos sentidos da frase "uma arte popular" nesse manifesto seria: "a poesia concreta trataria de tornar a arte da poesia de novo uma arte popular, ou seja, possuidora de um público significativo, acessível como um programa de televisão ou uma novela de rádio". ${ }^{67}$

Outra questão nova identificada por Franchetti nesse artigo é "a associação do ideograma à televisão, aos anúncios etc. Deve-se notar que nos textos anteriores, o ideograma era apenas um componente de uma dada tradição erudita (...). Trata-se então - e esse será um dos maiores problemas teóricos da poesia concreta - , de apresentar a nova poesia como uma síntese de duas formas de produção simbólica basicamente distintas: a indústria cultural, os mass media, e a cultura erudita, a que pertencem os autores do paideuma concretista". 68

O texto de Pignatari, em mais uma tentativa de atualização da poesia, pretende, como observou Franchetti, numa mesma arte, incorporar formas de produção não só distintas, mas também contraditórias. Ainda nesse mesmo artigo, Décio Pignatari continua uma lista de procedimentos que são rapidamente enumerados: ${ }^{69}$

tática: joyce, cummings, apollinaire (como visão, não como realização), morgenstein, kurt Schwitters. estratégia: mallarmé, pound (junto com fenollosa, o ideograma).

\footnotetext{
${ }^{66}$ ORTIZ, Renato. “O mercado de bens simbólicos”. In: op. cit., p.114.

${ }^{67}$ Op. cit., p.56.

${ }^{68}$ Idem, p.57.

${ }^{69}$ Paulo Franchetti comenta: "Os textos iniciais de Pignatari, junto com esse agora citado, permitem entrever algo que parece uma característica digna de nota: a facilidade com que esse autor, sem muitos cuidados, traça rápidos panoramas históricos em que não se precisam lugares, causas, nem circunstâncias. No presente caso, não fosse a recorrência desse procedimento, dispensaria comentários tanto a sua ingenuidade lingüística quanto seu pequeno vôo histórico (tão rude quanto impreciso)" (op. cit., p.58).
} 
a técnica de manchetes e \& un coup de dés\&. calder e \&un coup de dés\&. mondrian, a arquitetura, e joão cabral de melo neto. joyce e o cinema, eisenstein e o ideograma, cummings e paul klee. webern e augusto de campos. A psicologia da gestalt. ${ }^{70}$

A reflexão que se pode fazer sobre essas citações, por enquanto, é esta: os poetas concretos, ao se apropriarem de teorias e nomes representativos da cultura erudita, numa tentativa de inovarem mediante o "desenvolvimentismo", tornaram ainda mais evidente a "consciência de atraso", como definiu Antonio Candido, e o abismo que separa o mundo desenvolvido do subdesenvolvido. No entanto, os poetas concretos apresentam textos que prometem inovação, ao estilo do lema "50 anos em 5" do governo Kubitschek, como uma modernização/atualização rápida e forçada, sem muita reflexão ou questionamento.

Ao mesmo tempo em que as referências à cultura erudita nos manifestos e textos críticos só revelam autoridade e conhecimento de quem fala, também imprimem, imediatamente, nos discursos a marca do desenvolvimento, do ultramoderno. Porém, o simples fato de não haver crítica sobre o que vem de fora, o que já se pode notar com a enumeração rápida de nomes e teorias, como notou Franchetti, revela também a marca do subdesenvolvido, do dominado, daquele que, diante do novo e do desconhecido, adota-o como sua grande novidade, seja por consciente necessidade de atualização, seja por oportunismo.

Em "olho por olho a olho nu" (1956), Haroldo de Campos, assim como Décio Pignatari em texto anterior, propõe uma arte centrada no objeto:

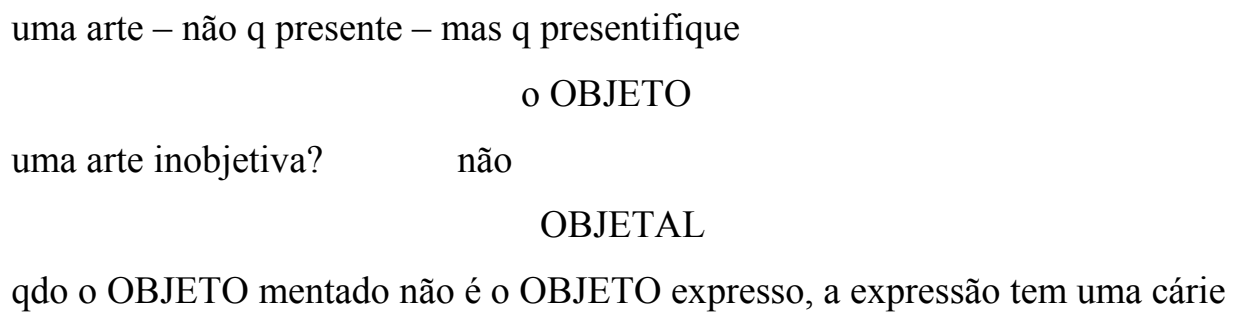
convenção literária)

\footnotetext{
${ }^{70}$ Teoria da poesia concreta, cit., p.48-49.
} 
um(a) novo (a) meio (língua)

POESIA CONCRETA: de ataque direto à

medula desse

OBJETO

atualização "verbivocovisual"

Do

OBJETO virtual ${ }^{71}$

Nessa citação, ao criticar o "uso cotidiano", Haroldo de Campos parece esquecer-se de que, em texto anterior, Pignatari propunha uma "arte popular", ou seja, uma arte que fosse também propaganda. Novamente aparece a idéia de poesia identificada com o objeto, designado aqui como "objeto virtual”, isto é, aquele em que significante e significado se equivalem - "quando o objeto mentado não é o objeto expresso" (ou seja, sem psicologia e anti-romantismo). Como há essa correspondência, a poesia concreta, agora “objeto virtual”, liberto de convenções, é igual a si mesma, é poesia no espelho:

O OBJETO mentado em suas plurifacetas: previstas ou imprevistas: veladas ou reveladas: num jogo de espelhos ad infinitum em q essas 3 dimensões 3 se mútuo-estimulam num circuito reversível libertas dos amortecedores do idioma de comunicação habitual ou de convênio livresco. ${ }^{72}$

O trecho traz alguns pontos para a discussão: o autor critica, tal como o "uso cotidiano", o "idioma de comunicação habitual". Porém, lembrando-se de que o "habitual" é estatístico, ou seja, ocorre maior número de vezes numa determinada quantidade de enunciados, parece haver nas duas expressões uma concepção meramente estatística. O conceito de "livresco", também ligado ao princípio estatístico e à teoria da informação, sugere formas já desgastadas. Ora, a questão que se levanta é a seguinte: como podem os teóricos da poesia concreta condenar o "livresco", o "uso cotidiano", o "habitual", e ao mesmo tempo propor uma arte vinculada aos veículos de informação - propaganda, televisão, rádio etc. -, que veiculam uma quantidade ilimitada de informações cotidianas, habituais e mesmo

\footnotetext{
${ }^{71}$ Idem, p.52.

${ }^{72}$ Idem, ibidem.
} 
livrescas, rapidamente processadas, consumidas e descartadas? Ao observar um poema concreto como terra, de Décio Pignatari, nota-se que o leitor não precisa de grandes elucubrações para "desvendar o poema". A palavra "terra" é fragmentada e esgotada em suas possibilidades combinatórias. O poema prevê uma espécie de totalização dedutiva, como a psicologia do todo proposta na Gestalt, uma visão simultânea e não-linear. A respeito, vale a pena conferir alguns trechos da análise de terra feita por Haroldo de Campos:

Na sétima linha - membro do poema terra - que até então vinha se compondo desta única palavra, articulando-se e desarticulando-se como a correr na fita de um teletipo ou na estética rolante de um noticiário luminoso - dá-se a súbita introdução de um elemento novo, gerado pelo próprio núcleo inicial: (...)

Um tópico da cibernética, correlato, deve ainda ser chamado aqui à cena: o método de solver problemas por "tentativa-e-erro", que interessa do mesmo modo aos psicólogos da "Gestalt". Como assinala W. Sluckin, o comportamento "tentativa-e-erro" pode ser descrito em termos de "feedback negativo".

Também o poema terra, concretamente, decifra-se a si mesmo. ${ }^{73}$ :

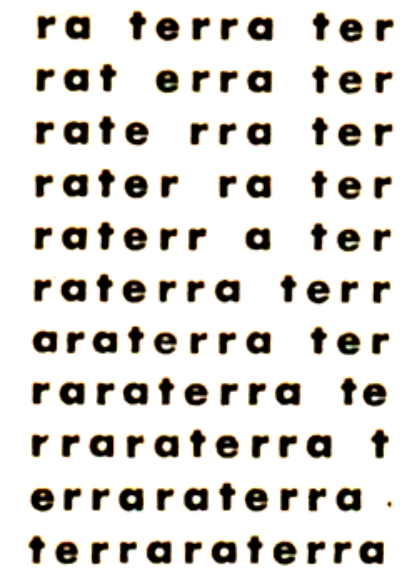

${ }^{73}$ Idem, p.79-80. 
A preocupação com os meios de comunicação, já vista no artigo de Décio Pignatari, é retomada por Haroldo de Campos, que destaca também a semelhança da poesia com o funcionalismo da arquitetura da Bauhaus, como objeto útil:

a POESIA CONCRETA é a linguagem adequada à mente criativa contemporânea permite a comunicação em seu grau mais rápido prefigura para o poema uma reintegração na vida cotidiana semelhante à q a BAUHAUS propiciou às artes visuais: quer como veículo de propaganda comercial (jornais, cartazes, $\mathrm{TV}$, cinema, etc.), quer como objeto de pura fruição (funcionando na arquitetura, p. ex.), com campo de possibilidades análogo ao do objeto plástico substitui o mágico, o místico e o "maudit" pelo ÚTIL

TENSÃO para um novo mundo de formas

$$
\begin{array}{r}
\text { VETOR } \\
\text { para } \\
\text { o }
\end{array}
$$

FUTURO. $^{74}$

Nota-se nesse trecho, como já foi visto em citações anteriores, que a poesia concreta é associada aos mass media, permitindo a "comunicação em seu grau mais rápido". Ora, com isso pressupõe-se que a poesia concreta, tal como os jornais, os cartazes e a TV, deva lidar com o presente. No entanto, o texto evidencia que a poesia concreta se direciona para o futuro.

Em "Evolução de formas: poesia concreta" (1957), Haroldo de Campos repete idéias do artigo anterior, como "presentificação do objeto" e "objeto útil", mas não fala mais em "veículo de propaganda comercial"; apenas vê nas "manchetes", "slogans", "cartazes" uma espécie de concorrência e a necessidade de atualizar a poesia com os mass media:

Dizemos que a poesia visa como nenhuma outra à comunicação. Não nos referimos, porém, à comunicação-signo, mas à comunicação de formas. A presentificação do objeto

\footnotetext{
${ }^{74}$ Idem, p.54.
} 
verbal, direta, sem biombos de subjetivismos encantatórios ou de efeito cordial. Não há cartão de visitas para o poema: há o poema. ${ }^{75}$

E ainda:

(...) O poema passa a ser um objeto útil, consumível, como um objeto plástico. A poesia concreta responde a um certo tipo de "forma mentis", contemporânea: aquele que impõe os cartazes, os "slogans", as manchetes, as dicções contidas do anedotário popular, etc. O que faz urgente uma comunicação rápida de objetos culturais. ${ }^{76}$

A tônica dominante do manifesto de Haroldo de Campos está em afirmar que "a poesia concreta, tal como a compreendemos, é uma resultante de um estudo sistemático de formas, arrimado numa tradição histórica ativa". 77 A comunicação de formas, não de conteúdos semânticos ("comunicação-signo"), implica atingir os hábitos do receptor, substituindo um modo da percepção por outro, descontínuo. Nesse sentido, a poesia concreta comunica o seu próprio código, como poesia que comunica estruturas, mais que conteúdos. É por isso, também, que faz referência contínua aos mass media: o que parece interessar, no caso, não é o conteúdo kitsch de massa, mas a homologia das formas de massa e das formas da poesia. Como já se sabe, incluem Mallarmé, Pound, Joyce, cummings, Apollinaire e certa parte do futurismo e dadaísmo. Ainda nesse texto, Haroldo de Campos cita Sartre e os formalistas russos na tentativa de mostrar que a idéia de "conteúdo" na obra de arte e, por extensão na própria poesia, está ultrapassada. Percebe-se que, em todos os textos vistos até agora, seus autores, sempre muito bem informados e dotados de uma reconhecível erudição que não lhes pode ser negada, embora sem questionar qualquer teoria ou recurso poético aplicado, visam a uma poesia que presentifique um objeto virtual e comunique, portanto, apenas sua estrutura.

Oliveira Bastos observa que:

\footnotetext{
${ }^{75}$ Idem, p.56.

${ }^{76}$ Idem, p. 58 .

${ }^{77}$ Idem, p.58-59.
} 
O poeta concreto não pretende "descrever", adequadamente ou não, a realidade. $\mathrm{O}$ que ele quer mesmo é que a linguagem verbal descreva o menos possível a fim de que, atenuado o seu poder de referência à realidade, o seu significado (termo final de um processo semiológico primário) possa ser transformado num significante, o poema concreto (termo inicial de um processo semiológico secundário). É nesse sentido, creio eu, que devemos traduzir a afirmação de Haroldo de Campos, para quem a poesia concreta não pretende uma comunicação de conteúdos e sim uma comunicação de formas. ${ }^{78}$

Após defender, assim como Augusto e Haroldo de Campos, nos artigos citados uma nova poesia, Décio Pignatari afirma em depoimento sobre a I Exposição Nacional de Arte Concreta:

... é bom dizer que não é a novidade ou a originalidade por si mesmas que nos interessam, mas a realização de uma poesia construtiva, direta e sem mistério, que dispense interpretação" - como diria Mondrian, muito bem lembrado por Haroldo de Campos. ${ }^{79}$

Outro artigo de Haroldo de Campos, "Poesia concreta - linguagem comunicação" (1957), não deixa de embarcar em citações de Korzybski (expostas por Hayakawa), Sartre, Fenollosa, Merleau-Ponty, Köhler etc., sem ao menos questioná-las. Tudo é um universo de certezas para o autor, mas não para o leitor atento:

A poesia concreta, ao buscar um instrumento que a traga para junto das coisas, uma linguagem que tenha, sobre a poesia de tipo verbal-discursivo, a superioridade de envolver, além de uma estrutura temporal, uma dimensão espacial (visual), ou, mais exatamente, que opere espácio-temporalmente, não pretende, com isso, uma descrição fiel de objetos, não é seu escopo desenvolver um sistema de sinais estruturalmente apto para veicular, sem deformações, uma visão do mundo retificada pelo conhecimento científico moderno. $^{80}$

Haroldo de Campos afirma que a poesia "verbal-discursiva" é uma arte da representação. Logo em seguida, diz que a poesia concreta é não-discursiva, ou seja,

\footnotetext{
78 "A poesia concreta e o problema da comunicação". Jornal do Brasil, 15 set. 1957. Suplemento Dominical, p.8.

${ }^{79}$ Teoria da poesia concreta, cit., p.64.

${ }^{80}$ Idem, p.75-76. Grifos nossos.
} 
é anti-representação, por isso ela não descreve (como, por exemplo, acontece com o parnasianismo), mas transfere, como estrutura atualizada em seu processo, a estrutura da fonologia, ou seja, elementos que em si são insignificantes, como fonemas, mas que se combinam e, ao mesmo tempo, substituem-se uns aos outros. A poesia concreta é uma poesia lingüística, ou, melhor dizendo, uma poesia $d a$ lingüística. Nota-se também que, embora nessa poesia não se faça uma "descrição fiel dos objetos", no trecho a seguir propõe-se uma poesia que se aproxime "da forma real das coisas". Não se trata, contudo, da forma fenomênica ou aparente das coisas, mas da forma "essencial" ou "real":

Pretende por esse rico e flexível instrumento de trabalho mental - dúctil, próximo da forma real das coisas - a serviço de um fim inusitado: criar o seu próprio objeto, porque, na realidade, elas serão sempre, no domínio espacial do poema, o objeto dado. Então uma linguagem afeita a comunicar o mais rápido, clara e eficazmente o mundo das coisas, trocando-o por sistemas de sinais estruturalmente isomórficos, coloca, por súbita mudança de campo de operação, seu arsenal de virtualidade em função de uma nova empresa: criar uma forma, criar, com seus próprios materiais, um mundo paralelo ao mundo das coisas o poema. $^{81}$

A seguir, Haroldo de Campos analisa o poema terra, de Décio Pignatari, com base nas teorias que expôs:

Também o poema terra, concretamente, decifra-se a si mesmo.

Mas não é só. Os demais elementos temáticos são outras tantas linhas de força a conduzir a estrutura-conteúdo: o poema gerando-se a si próprio, o erro ativo - erra arar - como uma terra que se autolavra (terra ara terra), uma rara terra, e no entanto uma operação tão terra a terra, tão elementar, tão característica da condição humana factiva como o ato do lavrador que roteia um campo. ${ }^{82}$

A interpretação feita por Haroldo de Campos seria contraditória lembrando-se de que em texto anterior fala de uma poesia que "dispense interpretação" - se não se tratasse, no caso, não de interpretação de conteúdos, mas

\footnotetext{
${ }^{81}$ Idem, p.76. Grifos nossos.

${ }^{82}$ Idem, p. 80.
} 
de interpretação de processos ativos na estruturação do poema de Décio Pignatari. Novamente, o discurso reitera a estrutura da poesia, recusando o que constitui como "conteúdo interior" (a expressão psicológica típica das vertentes românticas da poesia, como o expressionismo) e "conteúdo exterior" (a representação realista própria das vertentes representativas da poesia, como o parnasianismo). A poesia, no caso, comunica a estrutura que a constitui, num efeito de circularidade "poema código - poema - código", o que confere à leitura desses poemas, quase sempre, a impressão de "vazio", que é o da estrutura. Mas esse "vazio"corresponde justamente ao efeito pretendido - o de produzir, como diz Ferreira Gullar, "novas experiências perceptivas":

Com o poema concreto ocorre um fenômeno até certo ponto semelhante ao da metacomunicação: a diferença maior estará, porém, sempre, em que tal poema não cogita da comunicação de mensagens ou conteúdos exteriores, mas usa desses recursos para comunicar formas, para criar e corroborar, verbivocovisualmente, uma estruturaconteúdo. ${ }^{83}$

A segunda fase da poesia concreta, em que, segundo Décio Pignatari, ${ }^{84}$ predomina a forma geométrica ou matemática, encontra um correspondente teórico no artigo de Haroldo de Campos "Da fenomenologia da composição à matemática da composição" (1957). Nota-se que o autor justifica a mudança teórica, ou melhor, a matematização da teoria, ao dizer:

Poesia concreta: produto de uma evolução de formas. Implica uma dinâmica, não uma estática. Teoria e prática se retificam e se renovam mutuamente, num circuito reversível. ${ }^{85}$

Como se pode observar, o artigo propõe uma renovação teórica que, conseqüentemente, implica uma mudança prática e vice-versa:

A poesia concreta caminha para a rejeição da estrutura orgânica em prol de uma estrutura matemática (ou quase-matemática). I. é: em vez do poema de tipo palavra-puxa-palavra,

\footnotetext{
${ }^{83}$ Idem, p.86.

${ }^{84}$ Idem, p.92.

${ }^{85}$ Idem, p.96.
} 
onde a estrutura resulta da interação das palavras ou fragmentos de palavras produzidos no campo espacial, implicando, cada palavra nova, uma como que opção da estrutura (intervenção mais acentuada do acaso e da disponibilidade institucional), uma estrutura matemática, planejada anteriormente à palavra. A solução do problema da estrutura é que requererá, então, as palavras a serem usadas, controladas pelo número temático. (...) Será a estrutura escolhida que determinará rigorosa, quase que matematicamente, os elementos do jogo e sua posição relativa. ${ }^{86}$

Essa mudança proposta indica que o poema concreto é elaborado de antemão, com base em uma fôrma ou em uma estrutura prévia, idéia que racionalizou e radicalizou a teoria e foi motivo de discordância entre alguns membros do grupo, caso de Ferreira Gullar.

Logo a seguir, Haroldo de Campos propõe:

A visão integral da estrutura a ser projetada no papel é algo que qualifica de antemão na tarefa criativa, podendo orientá-lo mesmo num caso em que, na prática, a visão da estrutura resulte de (ou seja, provocada por) um jogo inicial de palavra-puxa-palavra. ${ }^{87}$

Haroldo de Campos admite que, mesmo que a teoria avance para a matemática da composição, na prática, visualmente, a estrutura poderá resultar no “jogo inicial de palavra-puxa-palavra”, ou seja, de um acaso.

E depois ressalta:

Todavia, a simples vontade de conceber o poema como um todo matematicamente planejado fará, uma operação criadora, pender afinal a balança para o lado da racionalidade construtiva. $^{88}$

Posteriormente, ainda em 1957, em depoimento intitulado "Aspectos da poesia concreta", Haroldo de Campos afirma:

O poema concreto vige por si mesmo. Ele se acrescenta ao mundo dos objetos como uma entidade nova, dotada de caracteres irreversíveis. Não é uma linguagem instrumental, não é

\footnotetext{
${ }^{86}$ Idem, ibidem.

${ }^{87}$ Idem, p.96-97.

${ }^{88}$ Idem, p.97. Grifos nossos.
} 
intérprete de objetos, mas sim um objeto por direito próprio. Como tal, ele não pretende destruir e superar o mundo objetivo natural, mas afirmar-se, autarquicamente, ao seu lado, como objeto-idéia, como coisa-poética, regido por suas leis específicas. Ao poema concreto podem-se aplicar as palavras de Jung sobre Ulisses de Joyce: "Du sagst nichts und verrätst nichts, o Ulysses, aber Du wirkst" (Tu nada dizes nem transmites, ó Ulisses, mas tu viges"). ${ }^{89}$

O trecho apresenta uma afirmação equívoca: o poema concreto "não pretende destruir e superar o mundo objetivo natural". As artes modernas destroem a representação desse tal "mundo objetivo natural", que o enunciado de Haroldo de Campos faz entender como "natureza", sem falar nada, contudo, sobre o "mundo objetivo artificial", a sociedade em que se vive. A boa arte justamente transcende ou supera tal mundo objetivo natural, livrando os homens do império da natureza. A proposta de construir um objeto, "coisa poética", regido por suas leis específicas é própria de toda a arte moderna, que destrói a significação e a expressão tradicionais para afirmar a transcendência do sentido. Haroldo de Campos afirma a vigência do poema como um objeto não-objeto, valendo lembrar que a não-ruptura do poema com o "mundo objetivo natural" pode implicar, no caso, o conformismo e o anacronismo das neovanguardas, como foi observado por Peter Bürger. Enquanto as vanguardas históricas romperam com a instituição arte, as neovanguardas criaram uma arte autônoma, paralela ao mundo natural. O que tentaram fazer os poetas concretos com a poesia concreta foi institucionalizá-la como arte, "arte geral da palavra", como observou Iumna Maria Simon. Percebe-se que os concretistas abandonam o verso, mas continuam a acreditar que estão fazendo poesia (antiliterária, é claro), como “objeto-coisa”.

O "Plano-piloto para a poesia concreta", de 1958, assinado por Augusto e Haroldo de Campos e Décio Pignatari, é o manifesto básico do movimento e talvez o texto mais conhecido da teoria da poesia concreta. Trata-se da repetição e síntese das principais idéias dos textos anteriores. O único elemento que chama a atenção

\footnotetext{
${ }^{89}$ Idem, p. 108.
} 
para esse texto é o post-scriptum de 1961: “sem forma revolucionária não há arte revolucionária” (Maiakóvski).

Com o "salto conteudístico-semântico-participante" anunciado por Décio Pignatari diante das idéias de revolução e participação social presentes nos anos 1960, os textos teóricos da poesia concreta desse período, numa tentativa de mostrar a preocupação social, trazem citações de Marx e Engels. É uma forma de os poetas concretos atualizarem o já velho plano-piloto diante das questões vigentes nos anos 1960. A citação de Maiakóvski pode ser entendida como um lema ou como um enunciado contra o organicismo romântico-realista, ou seja, como crítica da representação. No entanto, o enunciado apaga totalmente o fato de que Maiakóvski podia realmente dizer tal frase na situação da Revolução Soviética antes de Stálin, nos anos 1920, quando tinha o apoio de Lênin e todas as estruturas da ex-Rússia da economia ao sexo, da família à propriedade privada, das artes aos transportes e à propaganda - estavam sendo revolucionadas. Mas o que é uma "revolução estética" numa sociedade semicolonial e iletrada, em que a direita dá as cartas e o capital manda em todas as estruturas? Pode-se retomar aqui a idéia de Adorno vista na epígrafe da primeira parte desta dissertação. Uma revolução estética numa sociedade conservadora em todos os outros setores é obviamente uma arte controlada a priori, objetivamente - independentemente das boas ou más intenções de seus autores -, e controlada como um esteticismo.

Em "Contexto de uma vanguarda" (1960), Haroldo de Campos faz uma citação de Marx e Engels sobre o problema de uma literatura universal. ${ }^{90}$ Acatadas, as idéias tornam-se mais uma justificativa para a poesia concreta atualizar-se com seu tempo. Vale ressaltar que esse artigo, além de citar Marx, Engels, Norbert Wiener e a construção de Brasília, faz um balanço da poesia concreta, de suas pretensões internacionais e de sua repercussão no Ceará:

\footnotetext{
90 A citação, extraída do livro Sur la Littérature et l'Art, é a seguinte: "Em lugar do antigo isolamento das províncias e das nações bastando-se a si próprias, desenvolvem-se relações universais, uma interdependência universal de nações. O que é verdadeiro quanto à produção material, o é também no tocante às produções do espírito. As obras intelectuais de uma nação tornam-se propriedade comum de todas. A estreiteza e o exclusivismo nacionais tornam-se dia a dia mais impossíveis; e da multiplicidade das literaturas nacionais e locais nasce uma literatura universal" (Teoria da poesia concreta, cit., p.152).
} 
A poesia concreta fala a linguagem do homem de hoje. Livra-se do marginalismo artesanal, da elaborada linguagem discursiva e da alienação metafórica que transformam a leitura de poesia em nosso tempo - caracterizado pelo horizonte da técnica e pela ênfase na comunicação não-verbal - num anacronismo de salão, donde o abismo entre poeta-epúblico, tantas vezes deplorado em termos sentimentais e pouco objetivos. ${ }^{91}$

Entrou assim nossa poesia numa fase de exportação, o que, transpondo para a estética os postulados referenciais da "redução sociológica" de Guerreiro Ramos, é sinal da formação de uma "consciência crítica", que já não mais se satisfaz com a "importação de objetos culturais acabados", mas ainda de produzir objetos nas formas e funções adequadas às novas exigências. ${ }^{92}$

Pode-se dizer que esses dois parágrafos trazem duas questões cruciais para a discussão: o mercado do livro e do público e a ideologia nacionalista. Nas décadas de 1950 e 1960, problemas como a radical injustiça social, o analfabetismo e a miséria das populações eram evidentes. $\mathrm{O}$ acesso aos livros e a própria leitura eram restritos às classes privilegiadas. A divulgação dos textos críticos, manifestos e poemas da poesia concreta também se restringia aos principais suplementos literários do Rio de Janeiro e de São Paulo e à revista Noigandres, além de outras poucas, como Invenção, Tendência e Arquitetura e Decoração. As primeiras coletâneas comerciais de poemas concretos só começaram a ser publicados a partir de 1976.

O público leitor dos textos e poemas de vanguarda era formado basicamente por alguns poucos críticos, professores e estudantes, além dos próprios produtores dos movimentos. Segundo Roberto Schwarz, a consolidação de um mercado cultural somente ocorre a partir de meados dos anos 1960, e é na efervescência desses anos, segundo descreve, que se forma um público, basicamente de esquerda e ligado à produção ideológica, constituído por estudantes, artistas, jornalistas,

\footnotetext{
${ }^{91}$ Idem, p.153.

92 Idem, p.154. Citação de Haroldo de Campos.
} 
arquitetos, sociólogos, economistas e parte do clero, na visão do autor, um bom mercado que produz para consumo próprio. ${ }^{93}$

Ainda sobre o público, é importante observar que a teoria da poesia concreta praticamente se esquece dele. Quando os poetas concretos falam, por exemplo, de "arte popular", de uma nova arte associada aos mass media, tem-se a impressão de que o poema concreto, como a $\mathrm{TV}$, o rádio, vai atingir a grande massa. No entanto, para que isso de fato ocorresse, a poesia concreta precisaria primeiro sair do papel e virar anúncio, cartaz etc. Mas o abismo entre poeta e público parece continuar com a poesia concreta, na medida em que seu circuito é bastante restrito.

A segunda questão que pode ser discutida na citação de Haroldo de Campos é a idéia de "poesia de exportação". A idéia nacionalista de "exportação" sugere duas reflexões: a) os poetas concretos, diante da rejeição ou falta de atenção do público, resolveram encontrar, na exportação dos seus produtos, uma forma de ampliar a publicidade sobre o movimento, acreditando na velha idéia de que, sendo bem aceitos no exterior, voltariam triunfantes à nação; b) a poesia concreta já estaria tão avançada, tendo formado uma "consciência crítica", que não necessitaria mais de importar teorias. A própria referência a um sociólogo brasileiro, Guerreiro Ramos, comprovaria essa nova fase da poesia concreta.

Assim, a poesia concreta não é apresentada mais como uma linguagem que incorpora os mass media, mas que se associa a eles:

A poesia concreta pretende criar novas reações semânticas para a abordagem do produto estético, e se isto não se faz de um dia para outro, face ao lastro negativo das convenções e dos interesses contrariados, não há dúvida de que o produto concreto - mesmo para aqueles que não o aceitam como poesia - já se comunica na própria medida em que se dá esse repúdio e nas próprias associações que provoca com o mundo de realidades cotidianas cinema, televisão, técnicas da imprensa, propaganda, etc. - que nos cerca. Não importa de fato chamar o poema de poema: importa consumi-lo, de uma ou de outra forma, como coisa. A informação estética prescinde de etiquetas nominativas. (...)

\footnotetext{
93 “Cultura e política, 1964-1969”. In: O pai de família e outros ensaios. Rio de Janeiro, Paz e Terra, 1992, p.62.
} 
Nem por ser universal, deixa a poesia concreta, como arte geral da palavra, de se ligar imediatamente à linguagem popular, à gíria, à dicção infantil, às adivinhas, as modalidades de descante folclórico, etc. ${ }^{94}$

Diante do namoro da poesia concreta com tantas formas de expressão, da cultura erudita à popular, incluindo os mass media, o conceito de poesia concreta se amplia: "arte geral da palavra". Pode ser associada com os mass media e com quase tudo que à sua estrutura se associe: a gíria, a linguagem popular, as adivinhas etc.. Embora o grupo Noigandres tenha criado uma teoria da poesia concreta, nesse momento, para Haroldo de Campos, "não importa chamar o poema de poema". O que importa é que ele seja consumido de uma forma ou de outra.

Fecha-se aqui a fase "heróica" da poesia concreta, que vai de 1956 a 1960. Essa fase é normalmente dividida em dois momentos: o "orgânico-fisiognômico" e o "geométrico-isomórfico". No primeiro, a construção do poema subordina-se ao jogo palavra-puxa-palavra, dando lugar ainda à metáfora e à subjetividade (como ovonovelo, um movimento, o âmago do ômega...). No segundo momento, a composição do poema esgota as possibilidades combinatórias das palavras (como terra, uma vez, ver navios, forma, velocidade...). ${ }^{95}$

Verificou-se que a teoria apresentada desde o início da década de 1950, em sua busca por uma poesia atualizada com a cultura erudita (Mallarmé, Pound, cummings, Apollinaire...) e com o seu tempo (os mass media), produziu um poema estruturado geometricamente, permitindo uma composição não-figurativa e nãolinear ao mesmo tempo, com exceção de ovo novo no velho, de Augusto de Campos, que faz uso do método caligrâmico, em que há adequação gráfica do discurso verbal à forma figurativa do tema:

\footnotetext{
${ }^{94}$ Teoria da poesia concreta, cit, pp.153-155.

95 Essa proposta de divisão da poesia concreta em fases, bem como os exemplos estão no livro Poesia concreta, com seleção de textos, notas, estudos biográfico, histórico e crítico e exercícios de Iumna Maria Simon e Vinicius de Ávila Dantas (São Paulo, Abril Educação, 1982).
} 


$$
\begin{gathered}
\text { o vo } \\
n \circ v e \text { l o } \\
\text { novo no velho } \\
\text { o fitho em folhos } \\
\text { na jaula dos joelhos } \\
\text { intante em fonte } \\
\text { fe o f o i to } \\
\text { dentro do } \\
\text { centro }
\end{gathered}
$$

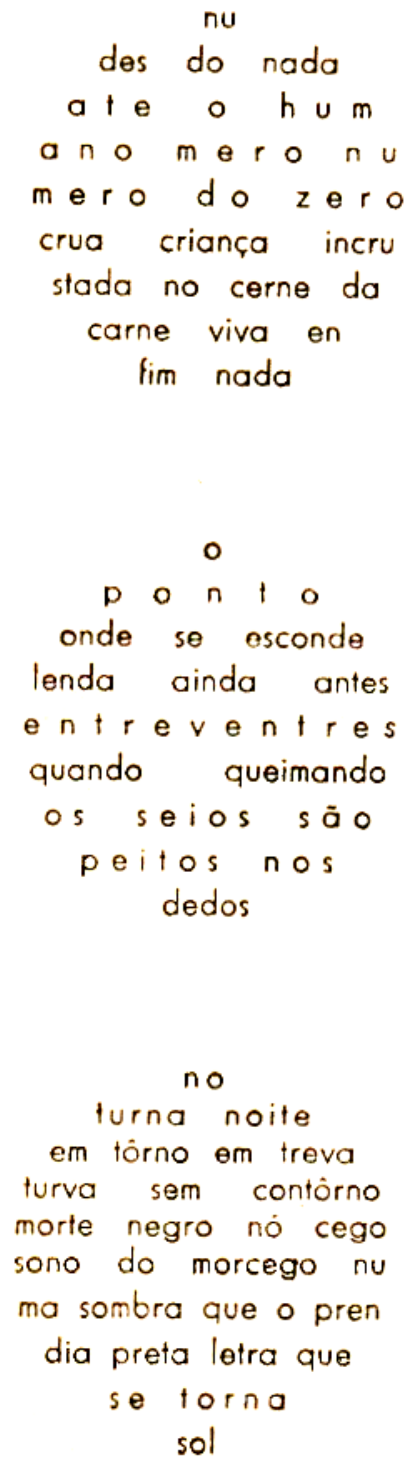


Em poemas como terra e velocidade, segundo Philadelpho Menezes, "a forma se desenvolve num processo análogo à dinâmica que caracteriza o tema objeto do poema". ${ }^{96}$ Ou seja, o poema recupera processos do futurismo, como o poema a seguir de Ronaldo Azeredo, em que a palavra "velocidade" vai surgindo linha a linha do poema, como se estivesse correndo na página:

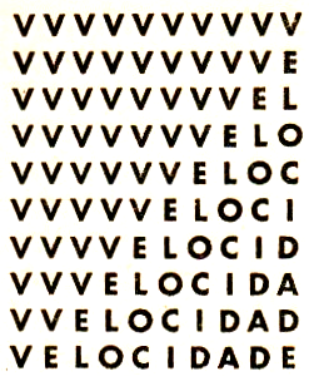

Ainda de acordo com Philadelpho Menezes:

A novidade do procedimento composicional da poesia concreta está na instauração de uma nova sintaxe baseada nas relações de semelhança entre as palavras: uma parataxe. A relação paratática entre as palavras se apóia numa ordem geométrica que organiza a disposição das palavras na página, substituindo a ordem sintática pela posição do signo verbal frente a outro. (...)

Deduz-se, então, que os elementos da composição característicos da poesia concreta são a organização geométrica do espaço e o jogo de semelhanças de significantes. ${ }^{97}$

Inaugurando uma nova fase da poesia concreta, em 1961, Décio Pignatari apresenta sua tese-relatório "Situação atual da poesia no Brasil", 98 que discute a questão participante na poesia de vanguarda. O polêmico "salto" anunciado por Pignatari é mais uma tentativa de atualizar-se no tempo: os acontecimentos políticosociais nos primeiros anos da década de 1960, tensionados por uma intensa

\footnotetext{
${ }^{96}$ Op. cit., p.30

${ }^{97}$ Idem, p. 21, 32.

98 Tese apresentada no II Congresso Brasileiro de Crítica e História Literária, na FFCL de Assis-SP, em julho de 1961. Cf. PIGNATARI, Décio. Contracomunicação. São Paulo, Perspectiva, 1971, p.91-109.
} 
mobilização popular, criam a necessidade de compromisso social dos artistas e intelectuais. $^{99}$

Mário Chamie, que investe sua crítica à poesia concreta, faz um comentário significativo sobre a tese-relatório de Pignatari:

Sigamos, então, o pensamento de Pignatari: ele presume (e vou admitir a presunção) que a primeira grande totalização da poesia contemporânea é a concreta; entende por "poesia contemporânea" aquela que é projetada e esclarece que esta é "a única poesia conseqüente do nosso tempo". Postos esses conceitos que são dele e não meus, Pignatari expõe as condições do pulo. Quais são elas? A primeira é a de que é uma incógnita "até onde pulará para trás, para o êxito do verso". Como uma incógnita é uma questão em aberto, temos de supor muita coisa, inclusive que o salto seja todo ele para trás, isto é, que o concretismo volte inteiro para o verso. Se isso acontecer - e pode acontecer, conforme Pignatari - eu pergunto: em que fica aquela declaração ortodoxa, do planopiloto, de que o ciclo histórico do verso está encerrado? Os concretistas, por acaso, não fazem questão de participar e pertencer ao ciclo histórico que é o tempo presente?

E mais adiante:

A segunda condição é a da viabilidade do pulo prenunciar o fim da "poesia contemporânea". Lembra-se o leitor que, para Pignatari, poesia contemporânea é toda aquela que é projetada e ainda: que é a única poesia conseqüente do nosso tempo. Logo, Pignatari não exclui a hipótese de o pulo acarretar o fim (ou prenunciar) do próprio concretismo que, enquanto projeto, é a primeira grande totalização da poesia contemporânea. (...)

A terceira é a de que, apesar de tudo, o pulo "tem de ser dado". A quarta condição é a de que, embora o pulo tenha de ser dado, não se sabe "quando" e "quem"o dará. (...) Por fim, a quinta condição é a de que o projeto é também coletivo no tempo. Essa condição inclui um descortinado sentido de participação ideológica. (...)

Assim se devemos agir para transformar algo (uma sociedade, uma situação dada, uma literatura), devemos ter consciência e responsabilidade da ação, excluindo as hipóteses que nos levam ao risco da reversibilidade, à semelhança dos concretistas que ameaçam voltar

\footnotetext{
${ }^{99}$ Cf. SIMON, Iumna Maria \& DANTAS, Vinícius. "O pulo da onça”. In: Poesia concreta, cit., não pag.
} 
ao encerrado ciclo histórico do verso, ao mesmo tempo em que proclamam não abrir mão dos processos que os levaram a decretar o fim desse ciclo. ${ }^{100}$

Nota-se na tese de Pignatari, conforme apontou com pertinência Mário Chamie, um rompimento com todos as certezas apresentadas nos textos teóricos anteriores. É a primeira vez, pode-se dizer, que as dúvidas sobre o destino da poesia concreta aparecem.

Segundo Iumna Maria Simon e Vinícius Dantas:

A produção concretista desta fase reflete as contradições ideológicas daquele momento histórico, bem como os impasses que se criaram no interior do próprio projeto. Os concretistas assumem as tarefas do engajamento, mas resistem aos próprios termos em que esse engajamento é colocado na época: poesia como "mensagem", palavra de ordem, facilidade de compreensão, diluição. A tarefa política consiste, ao contrário, em quebrar hábitos de leitura, resolver maneiras de pensar, negar as formas estabelecidas de comunicação. A relação dos poemas com as tarefas imediatas da participação e da comunicação poéticas é, portanto, contraditória, assim como tinha sido, na fase precedente, a relação entre poema-objeto-útil e as exigências do consumo. ${ }^{101}$

Outro texto lançado nessa fase, "A poesia concreta e a realidade nacional", é um desenvolvimento e atualização das idéias apresentadas em "Contexto de uma vanguarda", ambos de Haroldo de Campos. O autor levanta as seguintes questões:

Pode um país subdesenvolvido produzir uma literatura de exportação? Em que medida uma vanguarda universal pode ser também regional ou nacional? Pode-se imaginar uma vanguarda engajada? ${ }^{102}$

Vale notar que as respostas para essas perguntas já parecem previsíveis: todas dizem respeito à poesia concreta. $\mathrm{O}$ poeta se vale de exemplos para justificar a "nova fase" da poesia concreta: a antropofagia de Oswald de Andrade, que traz a idéia de literatura de exportação; Marx, Engels, Guerreiro Ramos, João Cabral, João

\footnotetext{
100 "Disponibilidade". In: Alguns problemas e argumentos. São Paulo, Conselho Estadual de Cultura, 1969, p.107.

101 "O pulo da onça", cit.

102 Cf. revista Tendência, Belo Horizonte, n. 4, 1962, p.83.
} 
Paulo Franchetti observa que o "salto participante" teve importância "quase que exclusivamente teórica", ${ }^{104}$ lembrando as palavras de Pignatari:

A poesia concreta vai dar, só tem de dar, o pulo conteudístico-semânticoparticipante. Quando - e quem - não se sabe. Nem se será percebido, numa sociedade onde a poesia, sobre ser gratuita, é clandestina. (...). ${ }^{105}$

A crítica a essa nova fase anunciada por Décio Pignatari também pode ser notada nos comentários de Rui Mourão:

O que me parece decisivo para os concretistas é considerar as suas descobertas até agora preponderantemente de caráter técnico. Não que esteja a dizer que eles não tenham realizado ainda poesia ou se encontrem numa fase de puro experimentalismo. Apenas quero afirmar que, no seu trabalho, os resultados de natureza técnica preponderam sobre tudo o mais (...). A tarefa que se impõe aos concretistas neste instante, a meu ver, é a da conquista de uma expressão mais abrangente. Uma aquisição técnica exprime a atualidade do homem. Da mesma forma, uma determinada reivindicação política. A soma das duas, naturalmente, não chegará a exprimir nada além disso. O que precisa ser procurado é uma expressão para a atualidade da humanidade do homem. A questão é enfocar o homem e descobrir a forma para a transmissão dessa realidade que, sendo sempre nova, não admite qualquer idéia preestabelecida e só se entrega totalmente através de uma perspectiva de visão nova, e não apenas pretender construir poema sobre poema ou romance sobre romance, o que resolve em simples conquista de novas técnicas o problema da expressão. $^{106}$

O último artigo da Teoria da poesia concreta, "Nova linguagem, nova poesia" (1964), é um manifesto, assinado por Luiz Ângelo Pinto e Décio Pignatari, que anuncia uma nova fase da poesia concreta. $\mathrm{O}$ texto insere na teoria da poesia concreta a semiótica e seus elementos com base na Teoria dos Signos fundada por Charles Sanders Peirce e depois desenvolvida por Charles Morris.

A proposta é:

\footnotetext{
${ }^{104}$ Op. cit., p.76.

${ }^{105}$ Cf. Contracomunicação, cit., p.108.

106 Cf. "O salto concretista”. O Estado de S. Paulo, 9 set. 1961. Suplemento Literário, p.3.
} 
(...) a criação de linguagens projetadas e construídas para cada situação e de acordo com cada necessidade. Isto significa: 1- projeto e construção de novos conjuntos de signos (visuais, auditivos etc.) e 2- projeto e construção de novas regras sintáticas aplicáveis aos novos conjuntos de signos. (...)

Daí a idéia de uma linguagem na qual a forma dos signos seja projetada de modo a condicionar a sintaxe, dando margem a novas possibilidades de comunicação. ${ }^{107}$

O mais interessante é que os autores querem adotar uma "nova poesia", formulando a idéia do poema-código (ou semiótico) como "a forma dos signos projetada de forma a condicionar a sintaxe"; apesar da proposta de mudança radical, a poesia continua a ser concreta:

(...) parece-nos claro que mesmo o que há de mais radical nesta poesia não se desvincular - ao contrário - dos princípios básicos da poesia concreta. Continuamos, portanto, a chamar de concreta a esta poesia. ${ }^{108}$

Os dois poemas de Pignatari, apresentados no final do texto, dão uma noção mais clara da teoria exposta pelos autores. Grosso modo, nota-se que a estrutura do poema, que antes se compunha de palavras organizadas geometricamente no espaço, é substituída por figuras geométricas. Pode-se dizer que a poesia concreta agora se aproxima mais das artes visuais. Mas o uso dessas figuras realmente não elimina os princípios iniciais da poesia concreta, pois há uma chave léxica, como uma legenda, em que cada figura equivale a uma palavra. Para ler o poema, deve-se substituir as figuras pelas palavras. O resultado é uma seqüência que estabelece significados arbitrários, os quais só devem fazer sentido para o autor que os convencionou:

\footnotetext{
${ }^{107}$ Teoria da poesia concreta, cit., p.160-161.

${ }^{108}$ Idem, p. 162.
} 
2 poemas de
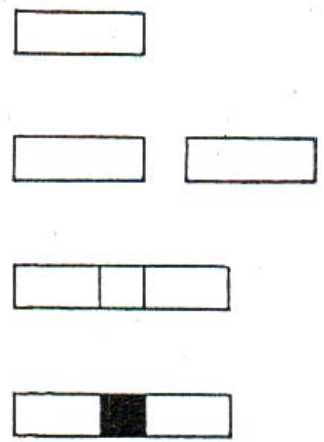

\begin{tabular}{l|l|l}
\hline & \\
\hline
\end{tabular}
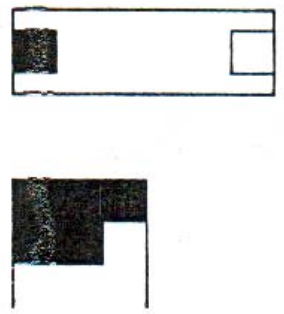

chave léxica
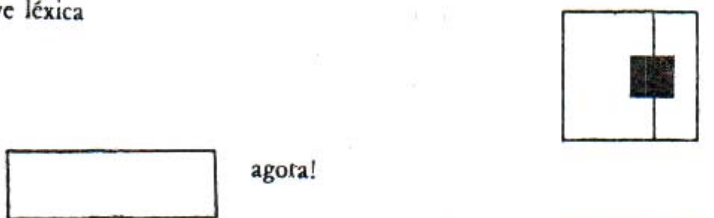

agora!

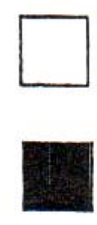

talvez

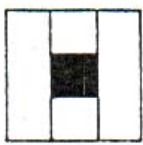

nunca!

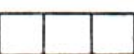



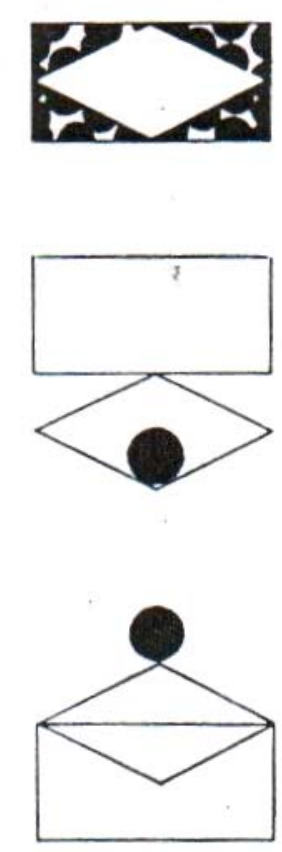

chave léxica
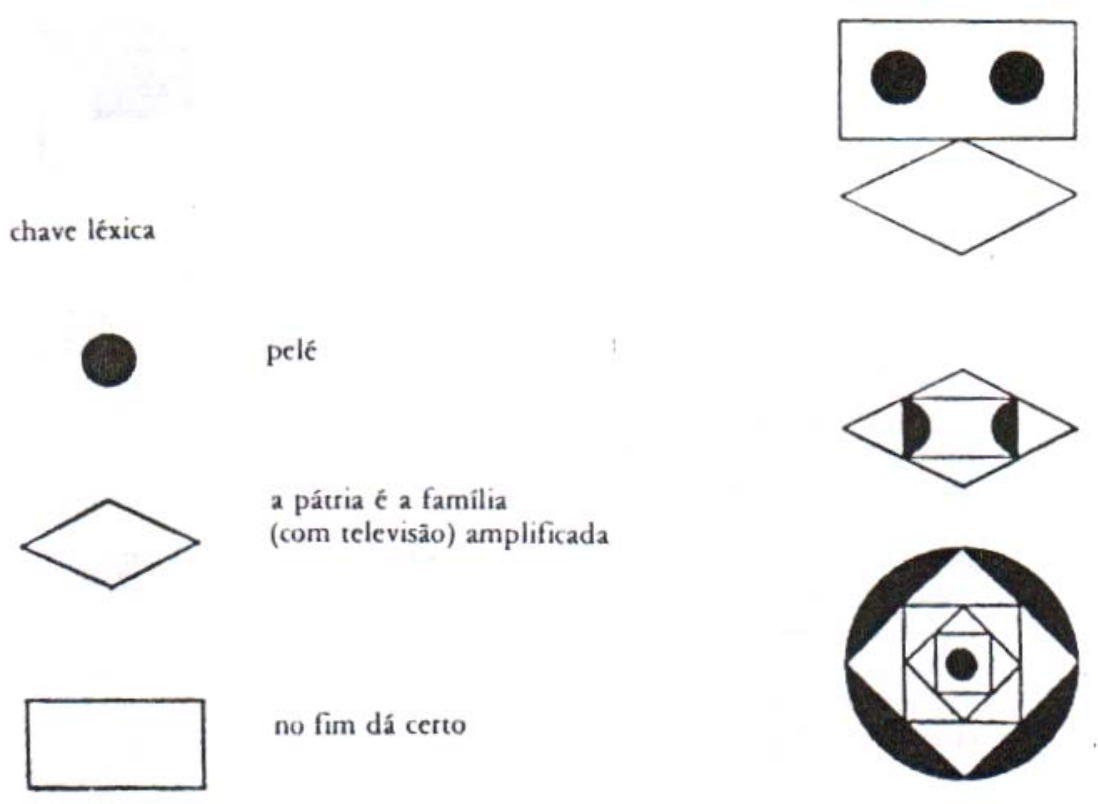

pelé

a pátria é a farnília (com televisão) amplificada

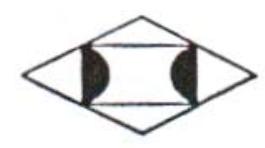

no fim dá certo

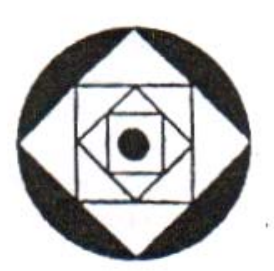

Segundo Philadelpho Menezes:

O poema, puramente visual e composto de figuras geométricas, por conseqüência não possui aspecto semântico intrínseco, pois a chave léxica estabelece significados arbitrários e convencionalizados pelo autor. O desenho do signo visual determina a sintaxe, 
o desenvolvimento concatenado das formas visuais, mas por ser uma cadeia de formas esvaziadas de sentido, toda informação para leitura conceitual se dá de modo postiço e por uma contínua realimentação com base no dado anexo e suplementar do poema (a chave léxica).

Os limites da poesia semiótica residem justamente nesta escassez de recursos de significados intrínsecos e naturais aos signos visuais. Se a questão fosse "nomear" a forma geométrica, bastaria qualquer chave léxica em apenso aos quadros de arte não-figurativa e teríamos "poemas visuais". A poesia visual estaria reduzida à denominação de formas por arbítrio do poeta. ${ }^{109}$

No artigo "Vanguarda como anti-literatura" (1965), Décio Pignatari fala em superação do mundo dos objetos:

O mundo dos objetos, das coisas-em-si, é um mundo em fase de superação. Entramos na era da linguagem. Do código e da mensagem. Da informação e da comunicação. A linguagem é a nova realidade objetiva de nosso tempo, a nova realidade universal. Tempo de signos. (...)

(...) A poesia nova cria antes quantidades do que qualidades, pois que é antes criadora de processo do que de produtos acabados. ${ }^{110}$

Nesse texto, o poeta já define a nova poesia concreta como anti-literatura, mas não descarta o uso do termo "poesia", que ainda parece abarcar tudo e qualquer coisa. Porém, na citação a seguir, observa a fuga necessária da poesia concreta das revistas literárias para as publicações voltadas para as artes gráficas, arquitetura, desenho industrial etc., ou seja, para todas as áreas que envolvam o visual.

Continua Décio Pignatari:

(...) a poesia concreta, poesia fundamentalmente de linguagem, provocou a ira dos "críticos do sistema", os quais tentaram e tentam amolecer o seu impacto renovador com as mais variadas artimanhas, a curto e a longo prazo, inclusive buscando forjar para ela uma classificação especial fora da "literatura"... E agora que surge uma nova modalidade de poesia concreta, poesia sem palavras, poesia de signos - na qual estão empenhados, desde

\footnotetext{
${ }^{109}$ Op. cit., p.57.

${ }^{110}$ In: Convivium (número especial sobre a poesia brasileira), ano IV, n .4/6, jul./ago./set. 1965, p.15-16.
} 
já, Wlademir Dias Pino, Luiz Ângelo Pinto, Ronaldo Azeredo e eu - agora que passamos para a criação de novas linguagens, um novo e duro golpe é assestado contra aqueles que rosnam "Isto já foi feito!", só para poderem continuar a fazer tranqüilamente o que de fato já foi feito. Nem é por outra razão que a poesia concreta pouco a pouco vai emigrando das chamadas publicações literárias para publicações mais atuais e atenuantes (sic): de artes gráficas, desenho industrial, arquitetura, semiótica - ou seja, para publicações onde se debatem os problemas de linguagem, de código, de informação e de comunicação. ${ }^{111}$

Essa citação é um exemplo de como a enunciação dos textos concretistas apresenta os autores como heróis, incompreendidos, à frente do novo. E, por isso, são rejeitados pela crítica, pelas revistas e suplementos literários. Essa é uma técnica retórica típica, pois não argumenta, enquanto faz asserções.

Observaram-se na trajetória da teoria da poesia concreta várias concepções de poema/poesia concreta, na seqüência: "um poema é idêntico a si mesmo", "arte geral da linguagem", "o poema é forma e conteúdo de si mesmo", "é linguagem adequada à mente criativa contemporânea”, "o poema passa a ser objeto útil, como um objeto plástico", "produto de uma evolução de formas", "o poema concreto vige por si mesmo", "arte geral da palavra", "poesia de signos". Essa diversificação de concepções, muitas vezes imprecisas e contraditórias, aponta para duas direções: a primeira pode ser representada pelas definições que atribuem um caráter único ao poema, "idêntico a si mesmo", como uma forma pura; a segunda apresenta o poema concreto como uma "arte geral" que, portanto, assume características e funções múltiplas.

Nota-se também que as práticas poéticas concretistas seguiram o seguinte percurso: primeiro, um esgotamento do verso, depois, da palavra e, por fim, da própria letra, substituídos, mais tarde, por códigos visuais. No descompasso entre teoria e prática, os poemas, muitas vezes, ora não chegaram ao alcance das teorias que projetavam um "poema-objeto útil" e, com o "Pulo da onça", um "poema participante", ora extrapolaram a teoria mais ortodoxa, criando sua própria teoria. De qualquer forma, a poesia concreta atualizou a concepção de poema com as

\footnotetext{
${ }^{111}$ Idem, p. 16.
} 
pesquisas mais recentes da ciência e da tecnologia e, com isso, criou um "objeto" em que, conforme afirma, o quantitativo converteu-se em qualitativo.

Vale destacar as considerações de Vilém Flusser sobre a poesia concreta:

As pesquisas lingüísticas dos poetas concretos são sintomas de consciência despertada. Mas ao ler os poemas concretos temos a sensação de uma força refreada, de uma aventura tímida, de um avanço cheio de reservas. Embora conscientes da sua tarefa, parecem os poetas concretos inibidos na sua tentativa de cumpri-la. Seja por concessões que fazem aos que continuam presos dos conceitos abstratos, seja por receio de um mergulho definitivo no caso (sic) do nada, não queimam os poetas concretos as pontes que os ligam à terra firme do significado externo. O resultado é, a meu ver, uma poesia híbrida que deixa apenas entrever a esperança daquilo que seria uma autêntica poesia concreta. ${ }^{112}$

Das várias aporias que se podem notar na poesia concreta, é importante destacar: o movimento propõe uma ruptura com o verso, mas não com a poesia/poema; com base em procedimentos extraliterários que são incorporados ao poema, normalmente fragmentados, busca uma forma pura, uma "arte autônoma".

Francisco da Rocha fala da dificuldade de criticar a poesia concreta:

Sem uma conceituação segura que permita uma estabilização de apreciação quer valorativa ou não; sem uma perspectiva quanto aos possíveis resultados das experiências de um grupo renovador, difícil se torna a atitude crítica. Daí não ter surgido até o momento uma crítica objetiva, fundada no exame equilibrado e racional das experiências dos poetas concretos. Sem o apoio nos argumentos que implicam uma formulação de idéias destinadas a abarcar todos os ângulos do problema, casulo de constantes filosóficas, sociais, poéticas, artísticas, etc., os observadores do movimento ora em curso se anulam praticamente. $\mathrm{O}$ campo de insinuação crítica fica dividido como um campo de batalha onde os participantes não sabem quais as armas a empunhar e quais são as ações a desempenhar. Sem recursos sólidos e críticos, no seu sentido lato e científico, os "julgadores" da poesia concreta ficam enclausurados em suas posições arraigadas, em seus preconceitos, em suas atitudes demarcadas por fronteiras conectadas direta ou indiretamente com situações quase sempre extraliterárias. ${ }^{113}$

\footnotetext{
112 “Concreto-abstrato”. O Estado de S. Paulo, 6 jun. 1964. Suplemento Literário, p.1.

113 "Sobre a poesia concreta", in Jornal do Brasil, 24 mar. 1957. Suplemento Dominical, p.2.
} 


\subsection{Poesia neoconcreta}

O neoconcretismo, movimento de curta duração ${ }^{114}$ criado por Ferreira Gullar, manifestou-se nas artes plásticas e na poesia, como o concretismo. Deve-se ressaltar que Ferreira Gullar, antes de inaugurar o novo movimento de vanguarda, participou ativamente do cenário artístico da época como poeta, crítico e teórico das artes plásticas. Em contato com o grupo concreto de São Paulo (entre artistas plásticos e poetas), participou da I Exposição Nacional de Arte Concreta expondo o poema $o$ formigueiro. ${ }^{115}$

A fase concreta de Ferreira Gullar, porém, durou pouco tempo. Em artigo "O poema concreto", de março de 1957, o poeta já desenvolvia uma idéia diferente da poesia concreta de Augusto e Haroldo de Campos e Décio Pignatari:

O problema da poesia concreta não é criar um novo modo de fazer versos, e sim tornar a linguagem o veículo de novas experiências perceptivas. O poeta concreto rompe rigorosamente com a tradição desde que essa tradição se identifica com determinados processos de comover o leitor.

Do ponto de vista técnico o espaço é o elemento novo fundamental que a poesia concreta utiliza: a distância entre uma palavra e outra, a posição da palavra em relação ao resto do poema, em relação à página inteira, etc., são fatores importantes para a leitura do poema concreto. É preciso ter sempre em mente que a distribuição espacial das palavras num poema concreto tem uma função rigorosamente expressiva. ${ }^{116}$

Meses depois, o "Suplemento Dominical" do Jornal do Brasil anunciou a cisão no movimento da poesia concreta. Na mesma página do Suplemento são

\footnotetext{
${ }^{114} \mathrm{O}$ neoconcretismo, como movimento teórico organizado inaugurado no Rio de Janeiro, manifestou-se de 1959 (lançamento do Manifesto Neoconcreto e I Exposição de Arte Neoconcreta) a 1961 (II Exposição Neoconcreta no MAM-SP e fim do Suplemento Dominical do Jornal do Brasil, principal porta-voz do movimento). Ver Projeto construtivo brasileiro na arte: 1950-1962, cit.

${ }^{115} \mathrm{O}$ poema, durante décadas, foi dado como desaparecido; veio à luz no início dos anos 90 . Gullar publicou também outros poemas concretos, como: mar azul, verde verde erva, árvore, fruta e outros. Cf. GULLAR, Ferreira. Toda Poesia. Rio de Janeiro, José Olympio, 2000.

${ }^{116}$ Jornal do Brasil, 17 mar. 1957. Suplemento Dominical, p.2.
} 
definidas, de um lado, a posição dos paulistas - com o artigo "Da fenomenologia da composição à matemática da composição", de Haroldo de Campos, anunciando a passagem da estrutura orgânica do poema para a estrutura matemática - e, de outro, a posição dos cariocas - com o artigo "Poesia concreta: experiência intuitiva", assinado por Ferreira Gullar, Oliveira Bastos e Reinaldo Jardim, que discordavam da "perigosa exacerbação racionalista" dos paulistas. O texto do grupo carioca define outras posturas para a poesia concreta:

A poesia concreta, tal como a entendemos e a defendemos, não é superior nem mais eficiente meio de expressão que as formas poéticas que a precederam; talvez mesmo seja, nesta fase de formação, menos rica e satisfatória que o verso medido e o verso livre em seus melhores momentos. Essas estratégias verbais dão testemunho dos interesses de um tempo cultural que já não é o nosso. A poesia concreta não é a invenção caprichosa de A ou $\mathrm{B}$, mas uma necessidade que escapa à órbita individual: é o resultado de uma evolução verificável da linguagem do poeta. Seu objetivo é substituir, sem prejuízo para a expressão, as formas poéticas fatigadas. ${ }^{117}$

Nesse trecho inicial do artigo nota-se que a posição assumida pelos poetas não impõe rupturas radicais nem posturas dogmáticas. Eles defendem a poesia concreta com certa simplicidade e modéstia, algo que não foi notado nos discursos dos paulistas, sempre carregados de arrogante superioridade em relação às formas poéticas que não estavam incluídas no paideuma.

Mais à frente, os poetas cariocas procuram definir e explicar a nova posição assumida na poesia concreta:

\section{Máximo de expressão - mínimo de palavras}

A poesia concreta não tem por objetivo a comunicação "mais rápida", senão na medida em que essa rapidez está implícita na economia natural do poema: o máximo de expressão controlado pelo mínimo de palavras.

\section{O poema ataca o sujeito}

117 Jornal do Brasil, 23 jun. 1957. Suplemento Dominical, p.1. 
A poesia concreta não é um meio "mais eficaz" de atacar o objeto, porque o "objeto" não preexiste ao poema, mas nasce com ele - o objeto é o poema: o poema ataca o sujeito (o espectador).

(...)

\section{Poesia e publicidade}

Assim, no poema concreto, o leitor é levado ao encontro de um objeto durável - e isto coloca o poema em oposição ao anúncio e aos processos publicitários em geral - onde a linguagem pretende apenas precipitar uma ação do leitor e não criar um objeto para ele.

\section{Poesia e subjetividade \\ (...) \\ O poema concreto é o novo meio de se controlar totalmente uma experiência. \\ (...)}

\section{Poema concreto}

O poema concreto quer ser o novo habitat vital da palavra.

\section{Totalidade transcendente}

O poema concreto deve valer como uma experiência cotidiana - afetiva, intuitiva a fim de que não se torne mera ilustração, no campo da linguagem, de leis científicas catalogadas. $^{118}$

Pode-se notar que, apesar de as definições dessa poesia não serem ainda muito precisas, muitos dos pressupostos dos poetas paulistas são negados, como a idéia da comunicação "mais rápida", do uso dos "processos publicitários em geral", da eliminação da subjetividade e da submissão do poema às leis científicas. Em oposição à publicidade, os cariocas propõem um “objeto durável”. Como uma vanguarda pode propor uma obra durável? É uma retomada da velha idéia metafísica da arte eterna que aqui é utilizada "em oposição ao anúncios e aos processos publicitários em geral". Além disso, mesmo que se faça essa oposição, o objeto continua a reproduzir o sistema já existente de produção/circulação/consumo

\footnotetext{
${ }^{118}$ Idem, ibidem.
} 
da poesia tradicional e da propaganda.

Ainda anterior ao manifesto da poesia neoconcreta, Ferreira Gullar, no artigo "Poesia concreta: palavra viva" (1958), reconhece certa limitação do poema concreto erva verde erva, de sua autoria:

Se o leitor se abstrair da disposição em que as palavras se encontram, perceberá que o poema é apenas a repetição seguida das palavras verde erva. Mas se obedece às pausas, pronunciando as linhas independentemente, então o poema se enriquecerá de inúmeras variações, entre duas formas limites: verde erva para erva verde. Pode o leitor, depois de tudo, objetar que o que um poema como este lhe dá, no fim de contas, é muito pouco. Sem lhe negar uma parte de razão, acredito que, se se tira da maioria dos poemas discursivos que hoje se fazem por aqui, o que neles há de herança automática, de truques, de lugares-comuns e de influências, muito pouco sobrará como contribuição do autor; talvez sobre em alguns casos a habilidade artesanal e noutros nem isso. ${ }^{119}$

$\begin{array}{ccc} & \text { verde } & \\ \text { erva } & \text { verde } & \\ & & \\ & \text { erva } & \text { verde } \\ \text { erva } & \\ \text { verde } & \text { erva } & \\ & & \\ & \text { verde } & \text { erva } \\ & \text { verde } & \end{array}$

Reinaldo Jardim, no “Flor não é a palavra flor" (1958), também demonstra insatisfação com a sua produção poética olho-alvo:

É um poema calculado em mesa de arquiteto. Consiste numa forma de três dimensões que se desloca sobre si mesma numa projeção de noventa graus, de maneira que

\footnotetext{
119 Jornal do Brasil, 23 fev. 1958, Suplemento Dominical, p.1. Comemorando um ano de poesia concreta, o caderno apresenta as assinaturas de Augusto de Campos, Décio Pignatari, Ferreira Gullar, Haroldo de Campos, José Lino Grünewald, Reynaldo Jardim e Wladimir Dias Pino.
} 
à proporção que essa forma se levanta sofre uma transformação radical em seu conjunto, apenas porque as palavras permanecem na horizontal, como todas as palavras que se prezam. (...)

Eu teria sido mais poeta se tivesse criado dentro desse esquema algo mais rico em substância que olho-alvo, alvo-olho. Mas a gente vai fazendo o que pode. Por mim continuo achando que devemos procurar fazer as coisas como gente e não como técnicos. ${ }^{120}$

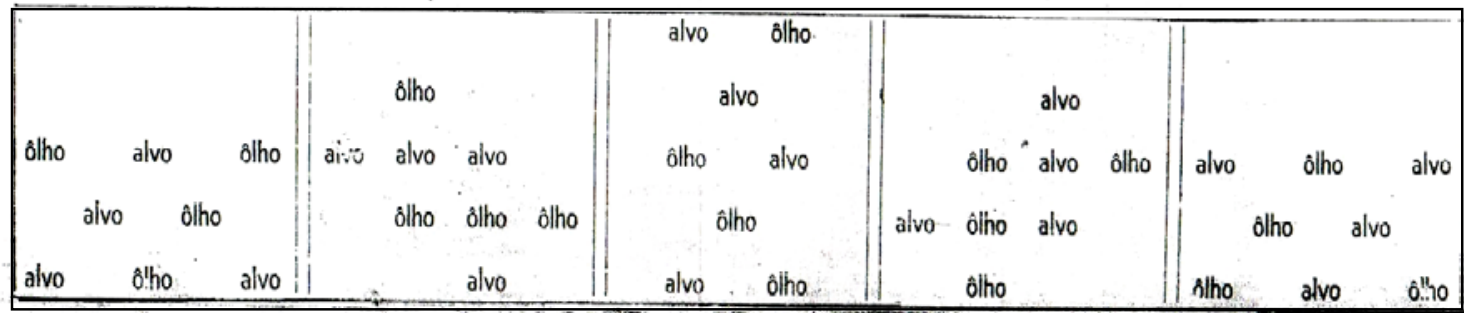

Observa-se que o poema segue o mesmo efeito-espelho de alguns poemas do grupo paulista. Como observou Oliveira Bastos, se por um lado a poesia concreta possibilitou a destruição da leitura unidirecional, por outro tornou "impossível impedir a formação de sintagmas e segmentos de frases insólitos e incontroláveis". ${ }^{121}$

As insatisfações do grupo carioca diante dos rumos tomados pela arte concreta (incluindo a poesia), que assumia uma postura racionalista, impulsionaram o lançamento do "Manifesto Neoconcreto", em 1959, inaugurando mais um movimento de vanguarda nas artes:

Não concebemos a obra de arte nem como "máquina" nem como "objeto", mas como um quasi-corpus, isto é, um ser cuja realidade não se esgota nas relações exteriores de seu elementos; um ser que, decomponível em partes pela análise, só se dá plenamente à abordagem direta, fenomenológica. Acreditamos que a obra de arte supera o mecanismo material sobre o qual repousa, não por alguma virtude extraterrena: supera-o por

\footnotetext{
${ }^{120}$ Jornal do Brasil, 23 fev. 1958. Suplemento Dominical, p.2.

121 "Bandeira e a poesia concreta". Jornal do Brasil, 23 fev. 1958. Suplemento Dominical, p.6.
} 
transcender essas relações mecânicas (que a Gestalt objetiva) e por criar para si uma significação tácita (M. Ponty) que emerge nela pela primeira vez. (...)

Essa posição é igualmente válida para a poesia neoconcreta que denuncia, na poesia concreta, o mesmo objetivismo mecanicista da pintura. Os poetas concretos racionalistas também puseram como ideal de sua arte a imitação da máquina. Para eles o espaço e o tempo não são mais que relações exteriores entre palavras-objeto.(...) Como na pintura, o visual aqui se reduz ao ótico e o poema não ultrapassa a dimensão gráfica. A poesia neoconcreta rejeita tais noções espúrias e, fiel à natureza mesma da linguagem, afirma o poema como um ser temporal. (...) A página na poesia neoconcreta é a espacialização do tempo verbal: é pausa, silêncio, tempo. Não se trata, evidentemente, de voltar ao conceito de tempo da poesia discursiva, porque enquanto nesta a linguagem flui em sucessão, na poesia neoconcreta a linguagem se abre em duração. Conseqüentemente, ao contrário do concretismo racionalista, que toma a palavra como objeto e a transforma em mero sinal ótico, a poesia neoconcreta devolve-a à sua condição de "verbo", isto é, de modo humano de apresentação do real. Na poesia neoconcreta a linguagem dura. ${ }^{122}$

$\mathrm{O}$ manifesto faz uma crítica aos procedimentos, ou melhor, às formas de conceber a obra de arte no concretismo, procurando, com isso, demonstrar os pontos de divergência entre os movimentos. É importante notar que, teoricamente, as diferenças são muito sutis. Pode-se dizer que estão no plano da percepção: o ponto de vista da Gestalt é adotado pelo concretismo. No neoconcretismo, Ferreira Gullar, em suas manobras anticoncretas, faz da fenomenologia (Merleau-Ponty e Suzanne Langer) o principal instrumento teórico do movimento diante do reducionismo tecnicista (baseado no cientificismo da cibernética, da teoria da informação...) do grupo concreto.

Enquanto a episteme concreta incluía o homem sobretudo como agente social e econômico, apesar da propalada autonomia da cultura, o neoconcretismo repunha colocações do homem como ser no mundo e pretendia pensar a arte nesse contexto. Tratava-se de pensá-lo enquanto totalidade. Era o retorno das intenções expressivas ao centro tradicional de subjetividade contra o privilégio de objetividade concreta. ${ }^{123}$

\footnotetext{
${ }^{122}$ Cf. GULLAR, Ferreira. Projeto construtivo brasileiro na arte: 1950-1962, cit, p.82-84.

${ }^{123}$ Cf. BRITO, Ronaldo. "As ideologias construtivas no ambiente cultural brasileiro". In: Projeto construtivo brasileiro na arte: 1950-1962, cit., p.305.
} 
Ferreira Gullar escreve vários textos após o manifesto que procuram levantar as diferenças entre a arte concreta e a neoconcreta e precisar as definições da poesia neoconcreta. É o caso de "Da arte concreta à arte neoconcreta" (1959):

A poesia neoconcreta não pretende criar estruturas que se bastem como formas visuais, mas libertar a palavra de suas limitações sintáticas, abrindo-lhe um campo expressivo novo. A poesia neoconcreta não é uma poesia do espaço e sim do tempo: não é uma poesia do tempo mecânico e sim do tempo verbal, da duração. (...)

A posição dos poetas neoconcretos como se vê é absolutamente adogmática. Não têm eles a preocupação de estabelecer princípios nem regras de composição. ${ }^{124}$

$\mathrm{O}$ artigo de Gullar estabelece uma diferença entre poesia neoconcreta e concreta: ao contrário desta, a poesia neoconcreta pretende libertar a palavra da estrutura visual e abrir-lhe um "campo expressivo novo", que vai se basear no “tempo verbal”. Daí, talvez, a idéia de "objeto durável” presente no primeiro texto. É interessante notar que, enquanto o espaço representa algo concreto na poesia, o tempo, que não é "mecânico", pressupõe uma abstração e um momento empírico.

Na seqüência, outro texto significativo de Ferreira Gullar é "Palavra, humor, invenção" (1960). Vale destacar as relações que o autor observa entre os artistas plásticos e os poetas quanto ao uso de elementos plásticos:

A arte neoconcreta, como se sabe, não se limita ao campo das artes plásticas, mas abrange o problema geral da expressão estética em nossa época. O movimento neoconcreto conta, desde sua origem, com a participação de pintores, escultores e poetas que, por sua vez, não restringem sua indagação a uma área definida e especializada. (...)

A um observador atento, que tenha acompanhado desde o início o trabalho do grupo neoconcreto, não escaparão, certamente, as relações existentes não apenas entre as obras dos artistas plásticos, como entre as destes e as dos poetas: não só os poetas adotam elementos plásticos nas suas criações, como os artistas plásticos imprimem ao seu trabalho uma participação manual - como no caso dos bichos de Lygia Clark - que estava no livropoema, onde o manuseio adquiria caráter expressivo. ${ }^{125}$

\footnotetext{
${ }^{124}$ Projeto construtivo brasileiro na arte, cit., p.113. Grifos nossos.

125 Idem, p. 157.
} 
"Teoria do não-objeto" (1959), também de Ferreira Gullar, é outro texto fundamental para a compreensão da arte neoconcreta. $\mathrm{O}$ autor defende sua teoria e, pautando-se em parte da história da arte, faz um percurso por Monet, Mondrian, Malevitch, Tatlin, Rodchenko, até convergir nas obras de Lygia Clark e Amílcar de Castro:

A expressão não-objeto não pretende designar um objeto negativo ou qualquer coisa que seja o oposto dos objetos materiais com propriedades exatamente contrárias desses objetos. O não-objeto não é um anti-objeto mas um objeto especial em que se pretende realizada a síntese de experiências sensoriais e mentais: um corpo transparente ao conhecimento fenomenológico, integralmente perceptível, que se dá à percepção sem deixar rasto. Uma pura aparência.

(...) o não-objeto não se esgota nas referências de uso e sentido porque não se insere na condição do útil e da designação verbal. ${ }^{126}$

Observa-se que, enquanto uma das definições teóricas da poesia concreta é a de "objeto útil", o poema em si como coisa, o grupo neoconcreto define a sua produção como “não-objeto". Mas, assim como a poesia concreta, a neoconcreta é também considerada um não-objeto nessa fase do neoconcretismo, pois ambas não fazem referência a um referente pré-totalizado. Deve-se lembrar que uma das definições da poesia concreta é "presentificação do objeto". A poesia neoconcreta, com o não-objeto, também deve incorporar uma noção semelhante:

É, pois o objeto, um ser híbrido, composto de nome e coisa, como duas camadas superpostas das quais uma apenas se rende ao homem - o nome. O não-objeto, pelo contrário, é uno, íntegro, franco. A relação que mantém com o sujeito dispensa intermediário. ${ }^{127}$

O não-objeto não é uma representação mas uma presentação. ${ }^{128}$

Sobre o problema da poesia na teoria do não-objeto, disse Ferreira Gullar:

\footnotetext{
${ }^{126}$ Idem, p.85, 90 .

${ }^{127}$ Idem, p. 152.

${ }^{128}$ Idem, p.91.
} 
Da mesma maneira que a cor libertou-se da pintura, a palavra libertou-se da poesia. O poeta tem a palavra, mas já não tem um quadro estético preestabelecido onde colocá-la habilmente. Ele se defronta com ela desarmado, sem nenhuma possibilidade definida mas com todas as possibilidades indefinidas. O que importa não é fazer um poema - nem mesmo fazer um não-objeto - mas revelar o quanto de mundo se deposita na palavra. ${ }^{129}$

Nessa citação, a teoria do não-objeto é estendida ao campo da poesia. Sem regras estéticas definidas para elaborar a poesia, o poeta tem apenas a palavra. Numa descrição totalmente insólita, em que não importa fazer um poema ou um não-objeto, o poeta tem a liberdade de criar qualquer coisa em que o mundo se deposite na palavra. Diante disso, ficaria impossível tentar definir um poema neoconcreto ou não-objeto. Pode ser tudo e nada ao mesmo tempo.

Para Gullar, o não-objeto na poesia é a procura de um lugar para a palavra:

É que a palavra ou está na frase - onde perde sua individualidade - ou no dicionário, onde se encontra sozinha e mutilada, pois é dada como mera denotação. O nãoobjeto verbal é o antidicionário: o lugar onde a palavra isolada irradia toda a sua carga. Os elementos visuais que ali se casam a ela têm a função de explicitar, intensificar, concretizar a multivocidade que a palavra encerra. (...)

No não-objeto os elementos plásticos não são usados com o mesmo sentido que na pintura ou na escultura. Já são escolhidos segundo um propósito verbal, isto é: da mesma maneira que um poeta tradicional elabora seu poema convocando e repelindo palavras, o poeta neoconcreto convoca, além das palavras, formas, cores, movimentos, num nível em que a linguagem verbal e a linguagem plástica se interpenetram. (...)

O espectador é solicitado a usar o não-objeto. A mera contemplação não basta para revelar o sentido da obra - e o espectador passa da contemplação à ação. (...) O não-objeto é concebido no tempo: é uma imobilidade aberta a uma mobilidade aberta a uma imobilidade aberta. (...) Diante do espectador, o não-objeto apresenta-se como inconcluso e lhe oferece os meios de ser concluído. (...)

O não-objeto reclama o espectador (trata-se ainda de espectador?), não como testemunha passiva de sua existência, mas como a condição mesma de seu fazer-se. Sem ele, a obra existe apenas em potência, à espera do gesto humano que a atualize. ${ }^{130}$

\footnotetext{
${ }^{129}$ Idem, p.93.

${ }^{130}$ Idem, p.94.
} 
O primeiro parágrafo da citação retoma a idéia do "lugar da palavra", e a poesia neoconcreta parece receber outro nome, o "não-objeto verbal". Logo a seguir, Gullar fala do poeta neoconcreto que interpenetra as linguagens verbal e plástica. Observa-se que a teoria do não-objeto põe em questão a possibilidade de definição dos gêneros pintura, escultura e poesia. Com isso, fica a dúvida: por que Gullar continua a usar as expressões "poeta neoconcreto" e "poema", se o nãoobjeto passa a ser uma categoria válida tanto para os "bichos" de Lygia Clark quanto para "poemas" como lembra ou pássaro do próprio Gullar?

Outro ponto fundamental dessa teoria é a afirmação de que ela está centrada no espectador. O não-objeto exige a participação ativa do espectador, o qual vai preencher de significação o poema. Segundo Philadelpho Menezes:

O não-objeto, formulado por Ferreira Gullar, é o signo que não substitui nem representa nada e sua existência depende da ação do espectador sobre ele, dando-lhe expressividade. ${ }^{131}$

Menezes afirma ainda:

A teoria do não-objeto propõe uma curiosa sobrecarga subjetivizante na leitura que transporta a estrutura geométrica para o campo do conceitualismo. Este caráter conceitual se dá pela exacerbação da importância do papel do leitor, enquanto indivíduo, como fator determinante na criação de significados não mais latentes nos signos, mas na vivência particular do leitor. O poema, pelo menos para a teoria, passa a ter seu nível semântico criado não mais pela organização e natureza dos seus elementos, mas pela ilação de sentidos que cada leitor faz dos dados do poema a partir de uma intimização que lhe toca a "vivência poética".

Os poemas que viriam a atender essa postulação teórica apresentam-se com um progressivo esvaziamento de significados inerentes aos elementos do poema, para se dar no ato particularizado e individual da manipulação do objeto-poema, enquanto vivenciar da experiência poética. ${ }^{132}$

\footnotetext{
${ }^{131}$ Op. cit., p.49.

${ }^{132}$ Idem, p.50.
} 
Como o neoconcretismo foi um movimento curto, de poucos textos teóricos e "poesias", não se pode falar propriamente em "fases", como ocorreu com o grupo paulista. Talvez isso se deva também ao fato de que o neoconcretismo não impôs regras ou valores estéticos rígidos. As obras normalmente se anteciparam às teorias. Deve-se lembrar que a cisão na poesia concreta ocorreu em 1957 e o manifesto neoconcreto só surgiu em 1959. No entanto, boa parte dos poemas produzidos nesse período não deixam ainda de encaixar-se nos parâmetros do grupo Noigandres. É o que se pode notar em algumas produções de Ferreira Gullar na década de 1950. Há em seus poemas a disposição das palavras no espaço em branco da página e a leitura multidirecional, como foi dito acerca dos poemas verde erva e olho-alvo. Gullar ataca a aplicação da Gestaltheorie pelo grupo Noigandres para conceituar tempo, espaço e estrutura no poema. Para o poeta, a apreensão desses elementos transfigura-se. Porém, as diferenças são ainda sutis do ponto de vista teórico e parece que não encontraram um caminho diretor no campo da prática poética:

Depois de um ano de lançado o movimento "concreto" na poesia, continuo incapaz de predizer o seu desenvolvimento futuro, as formas que deva ou não assumir. E não me lamento dessa incapacidade que, em compensação, afastando-me dos exaltados caminhos da profecia, aproxima-me do píncaro onde esse futuro - que não me preocupa - se elabora. Desse modo, não me seria possível, sem leviandade, sacar dessa experiência um catecismo poético. Posso apenas falar das pequenas descobertas que fiz ao tentar expressar-me sem os recursos tradicionais da poesia e - como não podia deixar de ser - sem me perder dos valores essenciais da linguagem verbal. ${ }^{133}$

Pode-se dizer que só por volta de 1959 as diferenças entre os dois grupos são mais bem definidas, com o lançamento do "Manifesto neoconcreto", da "Teoria do não-objeto" e dos livros-poemas de Gullar, Reinaldo Jardim e Lygia Pape. A partir desse momento, é possível falar de uma correspondência entre práticas e teorias com os "poemas" lua e ato, de Osmar Dillon, lembra e pássaro, de Ferreira Gullar.

133 GULLAR, Ferreira. "Poesia concreta: palavra viva". Jornal do Brasil, 23 fev. 1958. Suplemento Dominical, p.1. 


\section{Os poemas de Osmar Dillon requerem uma ação direta e concreta do} espectador para suas realizações. Sobre dois deles, ato e lua, escreveu Roberto Pontual:

Comecemos pelo não-objeto LUA. Constitui-se de uma placa quadrada de madeira na qual foram escritas as letras L e A, sobre fundo branco: uma superficie de vidro circular, na qual está escrita a letra U, gira em torno um eixo. Pelo conjunto de placa e vidro, portanto, fica formada a palavra LUA. Esse não-objeto (como aliás todos os outros de Osmar Dillon e também de Ferreira Gullar) só vive, só se realiza integralmente através da manipulação. (...)

A manipulação é, portanto, o fator que deflagra a significação do não-objeto (entenda-se por significação a que o não-objeto é, como um todo: torna-a presente e a encaminha até seu completar-se que, em verdade, nunca representa um findar da experiência, que pode continuar se processando indefinidamente. Aliás, esse não-objeto nada é, nada significa, antes que o seu manipulador resolva suster a manipulação. Só então ele se completa e atinge sua plenitude. Mais uma observação: ele nada representa de exterior a si próprio, é a pura apresentação de uma experiência não anterior à que ele atualiza: o perder e o ganhar-se da palavra LUA. E quem o manipula experimenta toda a experiência, sem que dela sobre qualquer resíduo de opacidade ou de incapacidade definitiva. $^{134}$

O autor aponta a importância das obras:

As obras desses artistas são, sobretudo, experiências que os diferenciam, como em nenhuma outra ocasião, dos resultados a que ultimamente têm chegado as pesquisas no âmbito do Concretismo: ressalta, antes de mais nada, o caráter eminentemente orgânico das obras criadas dentro de uma tendência geral neoconcreta e genericamente denominada de não-objetos verbais ou plásticos, em clara oposição às intenções e realizações da tendência concreta, que equaciona o problema no sentido de uma evolução do orgânico para o inorgânico. $^{135}$

\footnotetext{
134 "Poesia: uma nova experiência." Jornal do Brasil, 26 nov. 1960. Suplemento Dominical, p.3.

135 Idem, ibidem. Este mesmo processo de acionamento e manipulação do não-objeto por parte do manipulador é também aplicado aos poemas ato e ave, analisados no mesmo artigo.
} 
Os "poemas", ou melhor, os não-objetos verbais de Dillon e Gullar envolvem outros materiais além da palavra. O que se observa é que "as cores, dobras e movimentos tendem a explicitar e reforçar a potencialidade do signo verbal". ${ }^{136}$
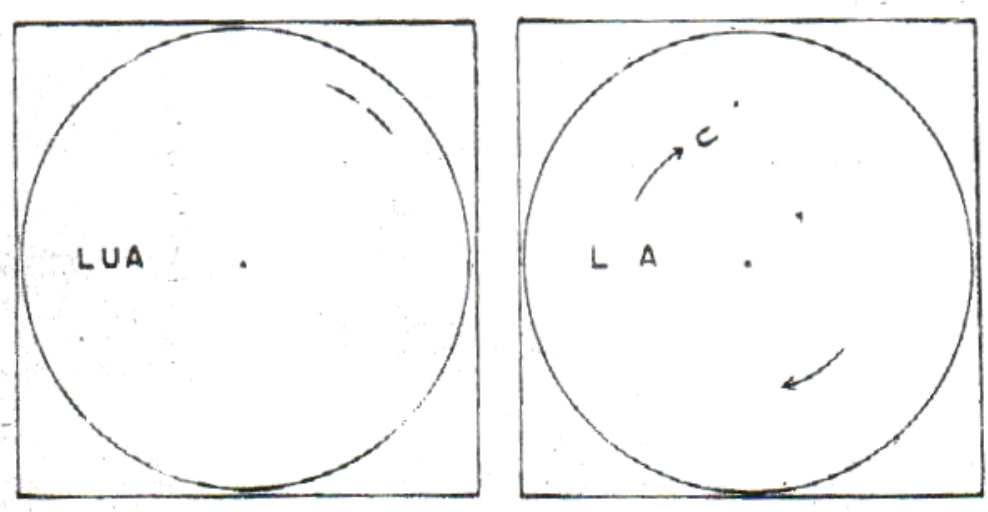

Poema lua, de Osmar Dillon.

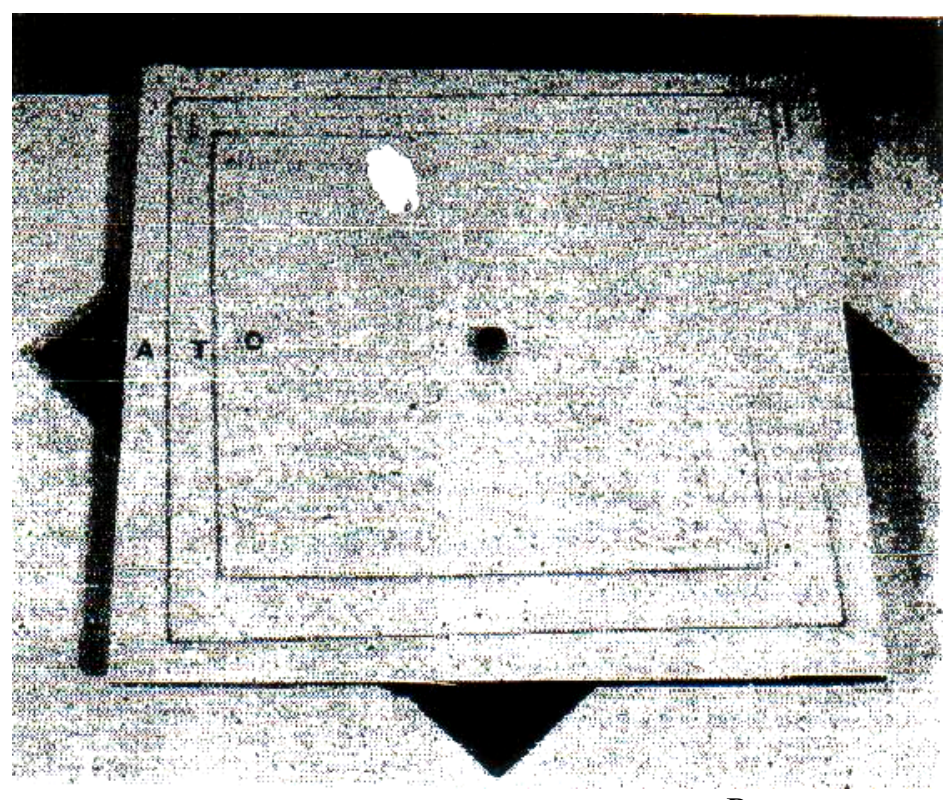

Poema ato.

Sobre os procedimentos usados nos não-objetos verbais, disse Roberto Pontual:

\footnotetext{
${ }^{136}$ Cf. MENEZES, Philadelpho, op. cit., p.50.
} 
Um dos argumentos que, com maior veemência, se vêm erguendo contra os nãoobjetos verbais de Ferreira Gullar, Osmar Dillon e Reynaldo Jardim ou contra o livro da criação e poemas-gravura de Lygia Pape, todos reunidos na II EXPOSIÇÃO NEOCONCRETA, é o de que neles sempre se observa o emprego de recursos não englobados pelas fórmulas tidas tradicionalmente como únicas de expressão poética. Iniludível é a presença de tais recursos naquelas obras: por vezes plásticos (formas, cores), por vezes mecânicos, entre outros, eles se apresentam de imediato, suscitando desde logo severas críticas na base da fórmula "poesia é linguagem, e apenas linguagem". Por certo, de um modo geral, o que fórmulas como essa pretendem é muito simples, simplório mesmo: o que não se puder considerar como recurso lingüístico (em suma, o que não for discurso, desenvolvimento conceitual), obviamente não poderá ser computado como elemento pertencente de fato ao corpo do poema. Daí a conclusão: poesia = substantivo + adjetivo + verbo + adjunto. ${ }^{137}$

Pontual chama a atenção para uma das principais críticas aos não-objetos verbais: o desrespeito "às fórmulas tidas tradicionalmente como únicas de expressão poética". Novamente, a poesia de vanguarda incorpora diferentes elementos e se utiliza de procedimentos que extrapolam o conceito usual de poesia e poema. Enquanto no grupo Noigandres o poema era um objeto autônomo visto como centro de poeticidade, o neoconcretismo deposita essa poeticidade no espectador e o objeto parece um pretexto para a poesia.

Sobre o poema pássaro, de Ferreira Gullar, disse Roberto Pontual:

O operador (já Mallarmé chamava o leitor de operador) depara, de início, com um cubo branco de madeira em que se eliminou uma das faces - a que para ele fica voltada permitindo ver que no seu interior foram inseridas, por meio de estrias abertas em dois lados paralelos, duas finas placas móveis, igualmente brancas. O cubo: ainda um objeto, sensível e possuidor de nome, mas opaco a uma apreensão integral. O operador dá início, então, à manipulação, retirando ao mesmo tempo do cubo as duas placas e separando depois uma da outra. Feito isso, descobre (em ambos os sentidos) a palavra PÁSSARO. E nesse exato momento - deflagrada a palavra, elemento verbal propriamente dito - o cubo, as duas placas, todos os elementos plásticos, enfim, adquirem uma significação que lhes

137 “O não-objeto verbal como síntese”. Jornal do Brasil, 17 dez. 1960. Suplemento Dominical, p.4-5. 
faz passar da condição de objetos à condição nova de não-objetos, não mais opacos e refratários à posse total. ${ }^{138}$

\section{Continua Pontual:}

É indiscutível que tais elementos têm, ou melhor, vão adquirindo um determinado significado no decorrer da manipulação, para, ao término do processo (ciclo do objeto ao não-objeto) constituírem um único significado-síntese, em essência produzido pelo elemento verbal (uma das diferenças que não se pode deixar de observar entre trabalhos de Gullar e os de Dillon é a de que enquanto nos primeiros a impregnação de significados nos elementos plásticos se faz repentinamente, num único lance logo que detonada a palavra, nos de Dillon a significação vai se elaborando pouco a pouco, em etapas que terminam por estabelecer um ciclo. ${ }^{139}$

Poema pássaro.

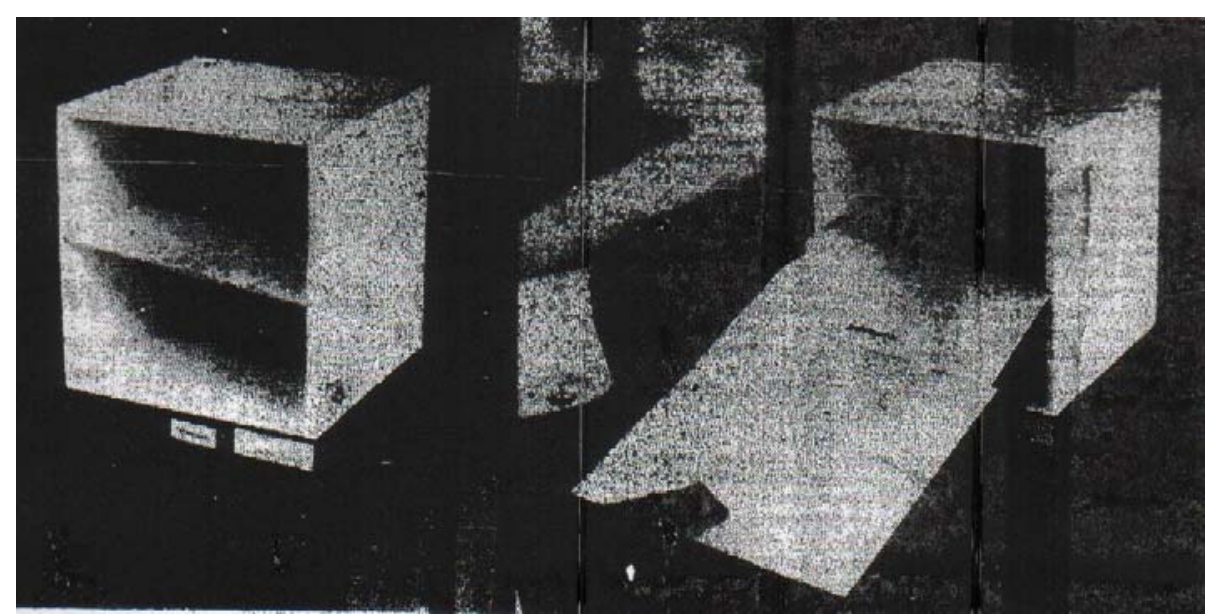

${ }^{138}$ Idem, p.5.

139 Idem, ibidem. 


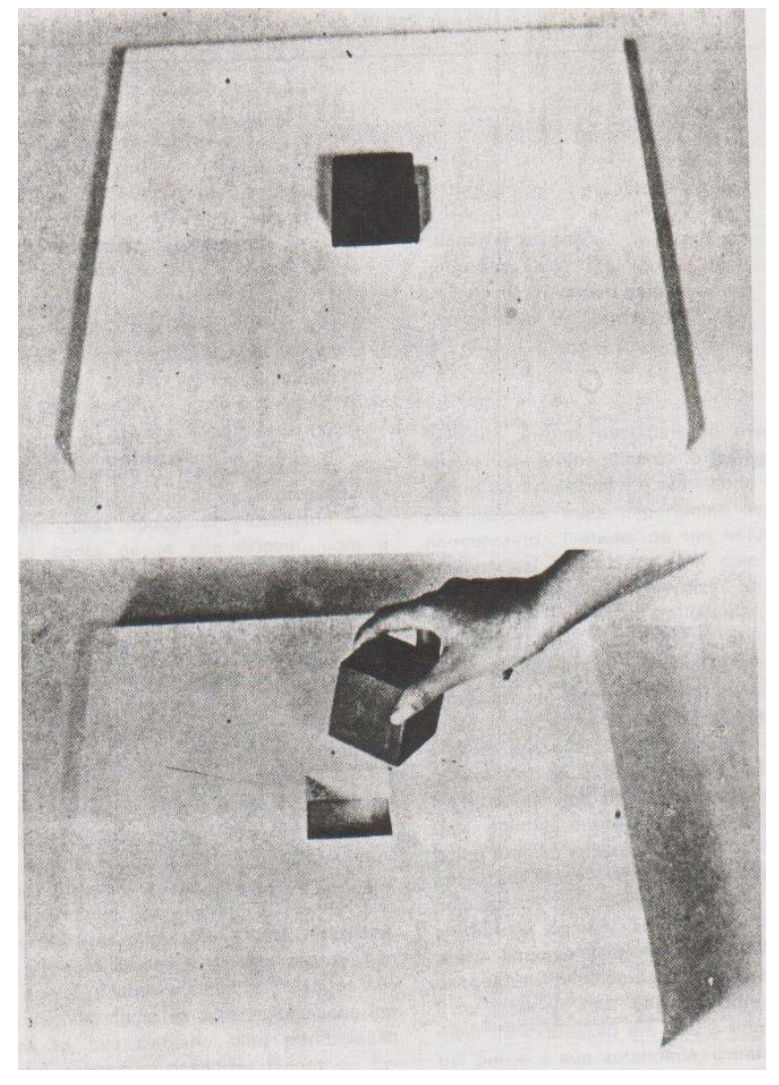

Poema lembra.

Na mesma linha do poema lembra, o poema enterrado, de Ferreira Gullar, é outro exemplo do imprevisível. Lá estava, no porão da casa de Hélio Oiticica, um cubo vermelho. Tira-se um cubo verde, depois um branco e, finalmente, aparece a palavra "rejuvenesça":

Uma antropofagia legítima. Assim Ferreira Gullar gosta de definir o neoconcretismo, um momento de sua arte que o impeliu a experiências extremadas. Os livros-poemas, cujas páginas tinham que ser cortadas e recortadas para formar a estrutura poética. Ou o poema subterrâneo, criado graças à iniciativa do artista Hélio Oiticica. No terreno da casa que dividia com o pai, Oiticica construiu uma sala de dois por dois metros, à qual se chegava descendo uma escada. No centro da sala, mantida na penumbra, ficava um cubo vermelho. Levantado o cubo, havia outro cubo verde. Levantado ainda este cubo, a palavra "rejuvenesça". ${ }^{140}$

${ }^{140}$ Cf. WYLER, Vivian.“25 anos depois, o neoconcretismo revisitado". Jornal do Brasil, 1 set. 1984. Caderno B, p.1. 
Como foi comentado nas páginas iniciais desta dissertação, tanto o concretismo quanto o neoconcretismo estão inseridos no período de "penetração das ideologias construtivas no Brasil e seu desenvolvimento como a única forma organizada de estratégia cultural que, ao longo dos anos 1950, principalmente, opôs-se às correntes nacionalistas, intuitivas e populistas, que culminaram com o CPC.

Nessa direção ampla, concretismo e neoconcretismo foram sem dúvida um par, são indissociáveis como respostas de certos setores frente à questão, do desenvolvimento social e cultural do país. E não bastará nunca recalcá-las sob o rótulo de 'vanguardas aristocráticas', nem obviamente acusá-las de alienadas politicamente." 141

A análise atenta de Ronaldo Brito sobre o neoconcretismo baseia-se na tese de que "o neoconcretismo representou a um só tempo o vértice da consciência construtiva no Brasil e a sua explosão". Assim sendo, é um objeto de estudo complexo, pois traz em seu interior os elementos mais sofisticados da tradição construtiva e também a crítica e a consciência implícita da impossibilidade da vigência desses elementos como projeto de vanguarda cultural brasileira. ${ }^{142}$

Observa-se que a poesia concreta não fugiu também à complexidade: traz elementos/técnicas da cultura erudita fundidos a recursos dos mass media, evidenciando a dificuldade de inserir suas obras no contexto social dos anos 1960. A poesia neoconcreta, por outro lado, nem chegou a mencionar a questão participante em algum texto ou poema. Talvez a única forma de participação encontrada pelo principal representante do neoconcretismo, Ferreira Gullar, tenha sido abandonar o movimento e aderir aos CPCs. Como lembrou o poeta:

Em 1961, fui convidado para dirigir a Fundação Cultural de Brasília, durante o governo Jânio Quadros. Ali entrei em contato com uma nova realidade, e isso teve uma importância muito grande para mim, porque, a essa altura, meu pensamento de nossas

\footnotetext{
${ }^{141}$ Cf. BRITO, Ronaldo. "As ideologias construtivas no ambiente cultural brasileiro". In: Projeto construtivo brasileiro na arte, cit, p. 303.

${ }^{142}$ Idem, p.304.
} 
experiências estava se tornando mais crítico. Cheguei à conclusão que se continuasse produzindo poemas espaciais não teria onde colocá-los. Havia chegado a um impasse. Nunca pretendi fazer poesia para entrar na Academia nem para me vangloriar. Sempre queria me comunicar com as pessoas, e senti que aquele caminho era justamente o da nãocomunicação. ${ }^{143}$

Em resumo, o neoconcretismo foi "uma vanguarda construtiva que não se guiava diretamente por nenhum plano de transformação social e que operava de um modo quase marginal", 144

Ronaldo Brito acredita que essa marginalidade seja uma das principais especificidades do neoconcretismo e que isso abriu caminho para uma crítica sobre o próprio estatuto social da arte, ausente nos movimentos construtivos.

Anos mais tarde, Ferreira Gullar concluiu:

O neoconcretismo não continha a solução para a crise: era expressão dela; mas expressão autônoma. ${ }^{145}$

Ronaldo Brito vê ainda duas vertentes no grupo neoconcreto: uma, que representa a tradição construtiva no Brasil e toma forma de uma sensibilização do trabalho de arte, com Franz Weissmann, Aluísio Carvão e outros; outra, que rompe (conscientemente ou não) com os postulados construtivistas e opera uma dramatização do trabalho, com Hélio Oiticica, Lígia Clark e Lígia Pape, que colocam em xeque o estatuto da arte vigente.

$\mathrm{Na}$ segunda vertente talvez se incluam os trabalhos produzidos na poesia neoconcreta por Ferreira Gullar, Reinaldo Jardim e Osmar Dillon, que também trazem uma atuação e uma dramatização em seus poemas.

\footnotetext{
143 "Os poetas concretos, 20 anos depois". "Texto/Entrevista", in Revista de Cultura Vozes, ano 71, n.1, p.99, jan./fev. 1977.

${ }^{144}$ Cf. BRITO, Ronaldo. "As ideologias construtivas no ambiente cultural brasileiro". In: Projeto construtivo brasileiro na arte, cit, p.307.

${ }^{145}$ Citado por Roberto Pontual. "Hoje do ontem neoconcreto". In: Projeto construtivo brasileiro na arte, cit, p.319.
} 


\subsection{Poesia Praxis}

Lançada em 1962 em "Manifesto didático", publicado originalmente como posfácio do livro Lavra Lavra, a instauração praxis, como é denominada por Mário Chamie, ${ }^{146}$ apresentou algumas "vantagens" e "desvantagens" 147 sobre as vanguardas poéticas anteriores: as poesias concreta e neoconcreta. A principal vantagem foi, talvez, a de ter sido lançada num momento em que estava em discussão ${ }^{148}$ o papel social da poesia ou a sua participação como "divulgadora" das questões sociais. Sendo assim, praxis já se atualizou em seus textos teóricos e procurou idealizar uma vanguarda poética que propusesse uma "reforma" estética e demonstrasse preocupação social.

Além disso, teve também a vantagem de tentar corrigir as falhas identificadas por Chamie nas poesias concreta e neoconcreta mediante as críticas dirigidas, principalmente, ao grupo Noigandres. Em relação à poesia concreta, essas vantagens também podem ser entendidas como desvantagens: praxis lançou-se depois da poesia concreta e, mesmo com características próprias, passou a ser acusada de oportunista e mero pastiche, "restauração" e "dissidência-diluição" da poesia concreta. Deve-se lembrar também que parte das críticas severas de praxis ao movimento concreto contribuíram muito para a rivalidade ferocíssima entre esses grupos e seus principais representantes; por último talvez se possa dizer que praxis não teve a projeção inicial da poesia concreta, pois esta, já em contato com a arte concreta, teve a oportunidade de ser lançada na I Exposição de Arte Concreta, ao passo que aquela foi lançada no posfácio do livro Lavra Lavra, de Mário Chamie.

\footnotetext{
${ }^{146}$ Mário Chamie fez parte da equipe Invenção. Há uma polêmica sobre sua saída da equipe. A versão dos poetas concretos é sempre mais divulgada. Segundo eles, o poeta praxis foi excluído da equipe. Porém, Chamie afirma que se desligou do grupo. Vale a pena conferir a versão de Chamie in "A página Invenção e eu" (Revista de Cultura Vozes, ano 71, n.1, p.27-30, jan./fev.1977).

$147 \mathrm{O}$ uso dos termos vantagens e desvantagens pareceu apropriado nesta análise, já que se trata de movimentos de vanguarda que, em seus agressivos confrontos pessoais, ideológicos e artísticos, revelaram uma disputa acirrada por uma posição central no cenário artístico da época.

${ }^{148}$ Cf. a tese-relatório "Situação atual da poesia no Brasil", de Décio Pignatari, apresentada no II Congresso Brasileiro de Crítica e História Literária, FFCL de Assis-SP, em julho de 1961.
} 
Assim como o neoconcretismo teve como teórico Ferreira Gullar, Mário Chamie foi o teórico de praxis e seu principal poeta. A idéia de um líder, nesses movimentos, mesmo que negada, nesse caso também é bastante óbvia.

Dos movimentos estudados nesta dissertação, praxis pode ser considerado mais profícuo em manifestos e plataformas, devido à grande quantidade de textos que publicou, alguns bastante extensos e complexos. Toda a teoria e alguns poemas do movimento estão reunidos em Instauração Praxis (dois volumes), e seus principais textos serão comentados a seguir.

No manifesto "Poema-Praxis" (1961), ${ }^{149}$ o poema-praxis "é o que organiza e monta, esteticamente, uma realidade situada, segundo três condições de ação: a) o ato de compor; b) a área de levantamento da composição; c) o ato de consumir". ${ }^{150}$ Seguindo essa disposição, Mário Chamie explica cada condição de ação, usando trechos de Lavra Lavra como exemplos. O ato de compor é formado por três elementos fundamentais: espaço em preto, mobilidade intercomunicante das palavras e suporte interno de significados. "Didaticamente", o autor define cada um dos elementos. Quanto ao "ato de compor", diz o poeta:

O poema-praxis tem seu primeiro momento no projeto semântico; ele é consciência constituinte e constituída* porque, nesta condição, é autônomo e independente ainda da área de levantamento. Muitos poetas ficaram no ato de compor e nele se alienam, Mallarmé é o líder. ${ }^{151}$

O "Poema-Praxis" sugere uma leitura de "trás para frente", pois, sem a explicação teórica, a boa compreensão do livro fica comprometida:

Vejamos, agora, a mobilidade inter-comunicante. Direi que sem o entendimento dessa mobilidade, o poema pode tornar-se um campo de defesa fechado ao leitor. Torna-se hermético. $^{152}$

\footnotetext{
${ }^{149}$ CHAMIE. Mário. Instauração praxis, São Paulo, Quíron, 1974, v.I, p.21-41. Esse manifesto, lançador da instauração praxis, foi publicado originalmente como posfácio do livro Lavra Lavra, em janeiro de 1962.

${ }^{150}$ Idem, p. 21 .

* "Essa consciência corresponde à fusão da dicotomia significante/significado."

151 Idem, p.21-22.

152 Idem, p.23.
} 
Mais à frente, o autor diz:

(...) O leitor que deseja fazer uma leitura crítica de Lavra Lavra deverá seguir o fluxo:

$$
\begin{array}{lcc}
\begin{array}{l}
\text { palavra unívoca } \\
\text { (isolada) }
\end{array} & \begin{array}{c}
\text { palavra multívoca } \\
\text { (em conotação) }
\end{array} \\
\text { (...) } & \text { (o poema) } \\
\text { (...) Lavra Lavra é livro sem verso (livre ou não); }
\end{array}
$$
discurso rítmico-linear e sim signos de conexão no espaço em preto. ${ }^{153}$

Ao explicar o terceiro elemento do ato de compor, o suporte interno de significados, o autor apropria-se dos conceitos da semiótica:

No suporte, as palavras aparecem nos diversos blocos de um campo de defesa semântico, constituindo-se em vetores contínuos e continuados que se irradiam a todos os signos, provocando-lhes a mobilidade inter-comunicante, até onde o espaço em preto o permita nos seus movimentos centrípetos e centrífugos. ${ }^{154}$

E ainda:

A outra órbita em que se destacam e vivem os vetores contínuos e continuados é a da semiótica. Esclarecemos que o nosso conceito de semiótica deriva do de Charles Morris, mas não nos prendemos a ele. $\mathrm{O}$ poema-praxis nos coloca diante de uma exigência de semiótica estética particular. ${ }^{155}$

Ao contrário de adotar apenas a teoria de Charles Morris, como fizeram Décio Pignatari e Luiz Ângelo Pinto no texto "Nova linguagem, nova poesia", Mário Chamie observa:

(...) Esclarecemos que o nosso conceito de semiótica deriva do de Charles Morris, mas não nos prendemos a ele. O poema-praxis nos coloca diante de uma exigência de

\footnotetext{
${ }^{153}$ Idem, ibidem.

${ }^{154}$ Idem, p.24-25.

${ }^{155}$ Idem, p. 26.
} 
semiótica estética particular. Sempre pensamos que a praxis se programa a si mesma, desde que sua ação seja um projeto semântico. O conceito de semiótica estética de Morris leva a uma generalização metafísica, apesar das importantíssimas informações práticas que oferece. $(\ldots)$

Para nós, a semiótica existe em dados-feitos e conforme esses dados-feitos. O poema-praxis é um dado-feito. Se não fosse assim, ele seria, mesmo escrito, mero pretexto de objetivação; seria talvez um despiciendo jogo irracional de acaso, uma confirmação teórica à base de um vício pensante. ${ }^{156}$

O último parágrafo não parece muito esclarecedor. O poeta define o poemapraxis como "dado-feito", mas não explica o que seria isso.

A área de levantamento da composição é definida rapidamente como uma realidade escolhida; no caso de Lavra Lavra, a situação do homem no campo. Segundo Mário Chamie:

(...) a área de levantamento supera e evita no ato de compor um puro esteticismo. É estética no domínio do campo de defesa, mas não permite ao campo de defesa ser autocrítico e auto-instrumentalista. É por não se determinar com esse fato que as últimas manifestações de vanguarda, no Brasil, não vencem o círculo vicioso da renitência estetizante. $^{157}$

Na citação, o poeta faz sua crítica ao "puro esteticismo" presente nas últimas vanguardas brasileiras, provavelmente concretismo e neoconcretismo, e demonstra preocupação em evitar esse caminho. A última etapa do poema-praxis é o "ato de consumir" ou "ato de leitura ao nível da consciência dos leitores": 158

O poema-praxis remodela o duo autor-leitor. O autor só é autor, enquanto no exercício da condição; enquanto pratica o ato de compor. Fora daí é leitor e, rigorosamente, no âmbito maior da literatura-praxis (de que o poema-praxis é uma extroversão), haverá um momento em que a riqueza criativa de um grupo, de uma sociedade e de um povo será constituída, quantitativa e qualitativamente, de leitores. (...)

\footnotetext{
156 Idem, ibidem.

${ }^{157}$ Idem, p. 31 .

${ }^{158}$ Idem, p. 38 .
} 
Paralelamente, o autor, como indivíduo, quanto mais integrado na coletividade de leitores (reais ou virtuais) tanto mais se integra na consciência de leitura. A literaturapraxis se estabelecerá, em definitivo, como fazer histórico, quando intelectuais e povo forem leitores de uma mesma linguagem. (...)

Não significa que devamos escrever para o leitor segundo a sua educação e o seu alcance intelectual, numa sociedade de privilégios. Não se trata disso. Trata-se de atender ao modo de ser dessa consciência projetada em dada situação. ${ }^{159}$

No primeiro parágrafo, Mário Chamie considera no "ato de consumir" o papel do autor que, ao deixar o "ato de compor", torna-se também leitor, mas um leitor intelectual. Nota-se, porém, que, para que se estabeleça e faça a sua história, a literatura-praxis deve atingir tanto os intelectuais quanto o povo. Como e quando isso vai ocorrer, o poeta não sabe. O que está implícito ou mal formulado nesse trecho é, de fato, a questão da divisão social e da divisão social do trabalho intelectual. A divisão do trabalho é trabalho de divisão em que intelectuais e "povo" estão separados. O tempo utópico em que intelectuais e povo seriam leitores de uma mesma linguagem também seria, teoricamente, o tempo em que estes seriam produtores de uma mesma linguagem. Ou seja: um tempo sem classes e sem divisão intelectual do trabalho. Assim, o horizonte (implícito) de praxis é o marxismo. A preocupação com a utilidade do poema é ressaltada também quando se diz que o poema-praxis "é útil, dentro e fora da literatura, porque atende ao modo de ser de nossa situação". ${ }^{160}$ Não se diz, porém, explicitamente qual é a situação, podendo-se supor que se trata da sociedade de classes em que a vanguarda não atinge o público.

Ainda segundo Chamie, o poema-praxis é:

A única totalização válida e não-alienada da consciência poética contemporânea. ${ }^{161}$

Constituindo a poesia concreta e neoconcreta como alienação, o autor lembra que praxis não propõe um trabalho com base em esquemas prévios e rígidos em que autores, obras e teorias são selecionados, aproximados e eleitos como parte válida

\footnotetext{
${ }^{159}$ Idem, p.31-32.

${ }^{160}$ Idem, p.39.

${ }^{161}$ Idem, p.41.
} 
da história, fonte da argumentação teórica, como fez o grupo Noigandres, mas busca "uma nova prática de rigor: o que se confere no resultado, na validade de um dadofeito original que totalize as três condições de um poema ou de uma obra praxis". ${ }^{162}$

A seguir, dois poemas de Lavra Lavra que acompanham o "Manifesto":

COMPRA E VENDA II

De mão a mão passa o produto passa.

A boca fecha.

De não e não o punho fecha.

Moeda passa para o negócio passa.

O tributo de sol a sol e a mão ao pão espera.

A boca abre
passa o produto e a tarde.

Mira mira

corre o dinheiro corre.

O bolso rega.

De trem a trem o trilho reza.

A féria corre para o balanço corre.

O meeiro de sol a sol e a mão ao pão estorque.

O bolso seca

corre o dinheiro à meca.

De dia a dia

pesa a proposta pesa.

O faro sente.

De mês a mês o lucro mente.

A venda pesa para o colono pesa.

A carroça de sol a sol e a mão ao pão esgueira.

$$
\begin{gathered}
\text { O faro falha } \\
\text { pesa a proposta e a palha. } \\
\text { De grão em grão } \\
\text { pleno é o celeiro pleno. } \\
\text { O jogo pende. }
\end{gathered}
$$

De pio a pio o bico plange.

A perda ganha para o consumo ganha.

$\mathrm{O}$ roceiro de sol a sol e a mão ao pẫo esconde.

O jogo finda

pleno é o celeiro e a finta.

\section{PLANTIO}

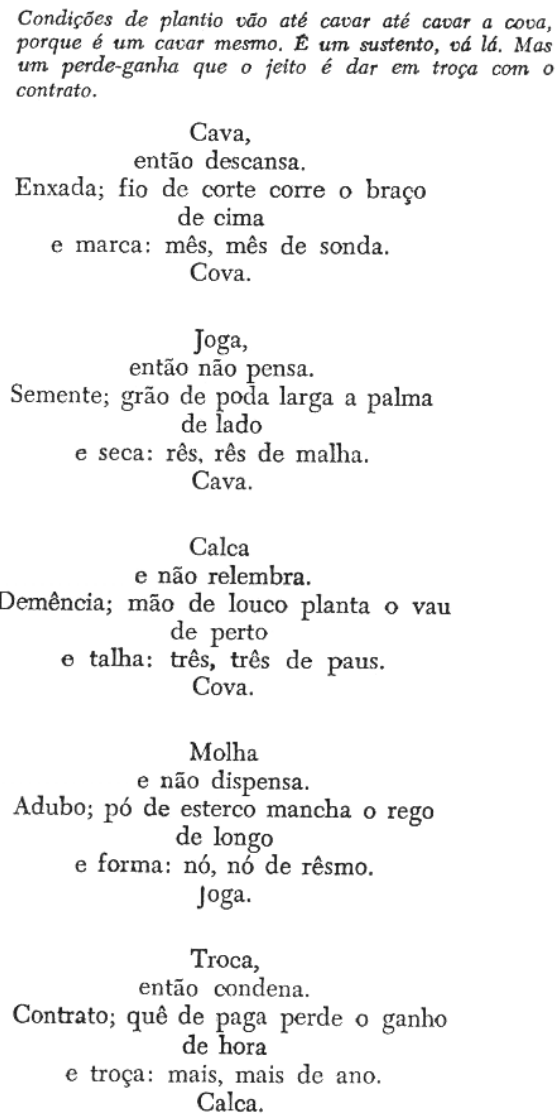

Percebe-se nos poemas de Mário Chamie que as palavras não estão presas a um mecanismo fixo, mas migram por meio de fonemas, repetições e reduplicações vocálicas, que percorrem a estrutura da composição. ${ }^{163}$ Outro aspecto que se deve destacar é que esses poemas além de apresentarem uma preocupação visual e formal, o "tema", que se resume nas várias situações vivenciadas pelo homem do campo, é problematizado, ou seja, em cada poema há uma carga controvertida e tensa - dialética. O poeta apresenta uma situação conflitante e dinâmica dos

\footnotetext{
162 Idem, p.35.

${ }^{163}$ RICARDO, Cassiano. Poesia praxis e 22. Rio de Janeiro, José Olympio, 1966, p.111.
} 
assuntos, o que imprime a sua poesia a consciência da realidade social própria dos anos 1960. Para Ivan Teixeira :

$\mathrm{Na}$ época do voto indireto, Mário Chamie fez escolhas políticas que o tornaram bastante esquecido, o que é compreensível mas não razoável. Houve ainda a polêmica com os concretos, que deve ter auxiliado o relativo ostracismo do poeta. Em alguns setores, é como se ele não existisse. Mas a própria poesia está cheia de política. Logo, não seria mal reler Mário Chamie, sem preconceito nem partidarismo. A história e a crítica não devem se orientar por circunstâncias de momento. A releitura de Chamie poderia começar por Lavra Lavra (1962), livro convincente sobretudo se se levar em conta o momento em que foi concebido, agitado pelo desejo de supremacia de várias vozes. Não se pode esquecer que, quando a Poesia Concreta fez crer que o verso estava morto, Mário Chamie empenhou-se na manutenção dele, praticando-o de modo denso e rigoroso, o que, paradoxalmente, tem sido o ideal de quase todos os poetas nas duas últimas décadas. ${ }^{164}$

\section{Sobre a teoria práxis, Teixeira observa:}

A teoria da Poesia Práxis, exposta em Lavra Lavra, é engenhosa, embora seu resultado possa ser apreciado sem tais pressupostos. Por sorte, isso sempre acontece no século XX, desde o "Prefácio Interessantíssimo", de Mário de Andrade. Atualmente, Lavra Lavra integra o volume Objeto Selvagem, que reúne a poesia completa de Mário Chamie até 1977, mas talvez devesse ser reeditado separadamente, em função não só de seu valor histórico, mas também para propiciar um contato mais específico com essa apreciável experiência construtiva, em que não raro a agudeza comparece como geometrização calculada da surpresa. Os poetas que, com soluções não-retrógradas, apostaram na permanência do verso durante a crise concretista, tendem hoje a se consagrar como heróis, pela obscura pertinácia na manutenção de um projeto paralelo ao da Poesia Concreta, que durante certo tempo foi a única opção a desfrutar de prestígio, a julgar pelo consenso da mídia e dos intelectuais. ${ }^{165}$

No texto "Manifesto, praxis e ideologia", de junho de 1962, Mário Chamie retoma a idéia de lançamento de uma nova poesia que supere o vanguardismo ou

\footnotetext{
164 "Rosa e depois: o curso da agudeza na literatura contemporânea (esboço de roteiro)". Revista USP, São Paulo, n.36, p.109, dez. 1997/fev. 1998.

${ }^{165}$ Idem, p.112.
} 
"vanguarda velha" no Brasil, especialmente o concretismo e sua condição de importador de autores e teorias. Para o autor, "os chamados movimentos de vanguarda são tópicos ideológicos de um 'estado' artístico que alimenta o mito literário e permanente da renovação pela renovação". ${ }^{166}$

Ainda na defesa de praxis, Chamie cita Maidanik ${ }^{167}$ ao comentar o ideologismo vanguardeiro:

E no que se refere às teorizações da arte, contamos com abundantes desenvolvimentos em cada setor, concluindo sínteses estimáveis do complexo cultural contemporâneo. Assim, a estética de Bense, a correlação industrialista na linha de Francastel, a teoria do símbolo e da forma e as associações morfologistas de diversas procedências, coordenam efetivamente elementos dados das disciplinas filosóficas, formais, físicas, estéticas; mas isso se restringe primordialmente ao plano técnico, falseando a concreta função revolucionária da arte. Desta maneira, seu divórcio em relação ao fundamento mesmo do processo social é consumado por causa de três omissões básicas: a ausência de uma interpretação sólida em termos de devir histórico; o escamoteamento dos mecanismos sócio-culturais do processo artístico; e a elisão de um conceito totalista, capaz de envolver a inter-ação do plano das idéias com o da ação transformadora. ${ }^{168}$

Para Mário Chamie essas três omissões dos preceitos do materialismo histórico e dialético do texto citado são fundamentais para se entender a ineficácia do "vanguardismo velho". Dessa forma, o poema concreto serve de exemplo dessa falsificação da "concreta função revolucionária da arte" ao incorporar à estrutura o processo cibernético da máquina regulando-se a si própria. ${ }^{169}$ Além disso, fechandose nas barreiras de sua "ideologia específica que se alimenta de si mesma", não pode "nunca totalizar uma situação social" $170 \mathrm{e}$, ainda, faz "o escamoteamento dos mecanismos sócio-culturais do processo artístico".

Praxis tenta fugir dessas três omissões, pois "é capaz de instaurar um

\footnotetext{
${ }^{166}$ Instauração praxis, cit, p.49.

${ }^{167}$ Cf. MAIDANIK, M. Vanguardismo y revolución (metodologia de la revolución estética). Montevideo, Alfa, 1960. Segundo nota do autor, in Instauração praxis, v.I, cit, p. 50.

${ }^{168}$ Citado por Mário Chamie, in Instauração praxis, v.I, cit, p.51.

${ }^{169}$ Idem, ibidem.

${ }^{170}$ Idem, p.52.
} 
ativismo permanente, uma transformação estatística variável, antiarqueológica. Isso porque só a praxis, individual e coletiva, mobiliza aqueles conteúdos vivos (...) Só ela, traduzida em comportamento criativo na literatura totaliza, em nível estético, uma situação". 171

Em "Literatura-Praxis (por uma consciência de leitura)", de 1962, o autor posiciona-se diante dos mass media:

Literatura-praxis: compreende a decadência de uma cultura verbal em face dos veículos de massa ( mass-media) - televisão, rádio, cinema. Além disso e por isso: procura introduzir elementos críticos nesses veículos e criar as bases de uma cultura informacional brasileira. ${ }^{172}$

Essa cultura informacional, segundo Mário Chamie, põe em jogo duas noções fundamentais: a de informação e a de popular. Para o autor:

A literatura-praxis que se instaura, no Brasil, é a primeira formulação crítica do problema que situa a produção da escrita fora do paralelismo e subsidiariedade ideológica e dentro de um projeto radical de transformação da sociedade. Ela incorpora a produtividade da praxis individual do artista no campo maior da participação, livrando-a da ameaça epifenomênica. Representa o primeiro momento da superação do exaustivo e riquíssimo ciclo de 22 . Configura a $1^{\text {a }}$ tomada crítica e criativa na série sucessiva de comportamentos individuais, totalizando a dinâmica de um comportamento coletivo. ${ }^{173}$

É importante notar como a citação está impregnada da ideologia presente nos anos 1960. Numa época em que se discutia a participação social e a idéia de revolução, a literatura-praxis apresenta um projeto ambicioso de "transformação da sociedade". O autor já vinha criticando a ideologia tecnicista presente na vanguarda anterior, mas abusa exagerando a centralidade e novidade do discurso transformador.

No artigo "Espaço em preto e autonomia" (1962), Mário Chamie identifica dois planos no poema-praxis: o plano da estruturação semiótica (composta por

\footnotetext{
${ }^{171}$ Idem, p.53.

${ }^{172}$ Idem, p.56.

${ }^{173}$ Idem, p.68. Grifos do autor.
} 
fisionomia crítica do poema, processo isomórfico de informação e geometrismo móvel) e o plano do espaço em preto. Vale destacar desses elementos, em confronto com o concretismo e o neoconcretismo, o espaço em preto. Contrário ao espaço em branco da poesia concreta, que para o autor é uma adaptação do espaço da pintura, o espaço em preto é “ocupado por palavras, se forma pela mobilização autônoma destas. O espaço em preto é inerente ao poema e se configura conforme o jogo centrípeto e centrífugo dos seus signos em conexão, dos seus segmentos e de suas linhas de palavras. Dependendo diretamente da intensidade da duração e do timbre de prolação de cada unidade componente de um bloco, ele varia de poema a poema e impõe uma fisionomia e um tipo de geometrismo sempre novo e imprevisível". ${ }^{174}$ Nada, porém, nessa formulação permite especificar exatamente qual é a diferença entre espaço branco concreto e espaço preto praxis.

Em "Matéria-prima, produção e poema", fragmento de ensaio de 1963, o autor fala em "leitura-produção", ou seja, o poema-praxis abre-se ao leitor para que ele produza outras estruturas no ato de leitura:

Apenas, os resultados obtidos pelo leitor serão outras estruturas, configuradas por ele e capazes de preencher outros vácuos de projetos não preenchidos pelo autor.

Nisso reside um dos fundamentais aspectos da revolução criativa operada pelo poema-praxis. Se os poemas tradicionais ou das vanguardas velhas se abrem, também, eventualmente a uma possível interferência do leitor, é na base estrita de identificação técnica do poema, na base de identificação do como-se-faz ou do como-foi-feito o poema. É na base ainda da submissão passiva do leitor, isto é, da manipulação mecânica que o torna num esperto decifrador de truques. Isso não alterará o velho hábito da leituraconsumo. ${ }^{175}$

Sendo assim, O poema-praxis, portanto, é exercício de co-autor. ${ }^{176}$

\footnotetext{
174 Idem, p.84.

${ }^{175}$ Idem, p.96.

${ }^{176}$ Idem, p. 97.
} 
Chamie concorda, inicialmente, que toda leitura é produtiva; no entanto, parece afirmar que tanto o poeta "tradicional" quanto o poeta concreto fecham as possibilidades dessa produção do sentido pelo leitor, na medida em que a poesia que fazem aplica modelos e estruturas pré-formadas pelo poeta. Assim, na sua proposta, Chamie parece entender que a função do poeta é a de ser um programador, ou seja, um organizador de elementos de determinada área semântica da cultura, os quais são propostos à leitura como peças de um jogo de permutação em que o leitor produz ou é co-autor num sentido, por assim dizer, ativo, diversamente do leitor coautor passivo ou limitado pela imposição do sentido autoral da poesia tradicional e concreta.

Outra idéia fundamental desse artigo é, em decorrência, a noção de "consciência coletiva de leitura":

Hoje importa menos - num contexto também pleno de dados novos como o nosso - a leitura das massas do que a consciência coletiva da leitura. Ainda que essa consciência seja, numericamente, representada por uma minoria ela não deixará de ser coletiva. Pois a questão é de projeto assumido por quem possa assumi-lo. E quem possa assumi-lo não o assumirá, sem introduzir nos seus poemas fatores de mediação, de co-produção, de coautoria. Um poema que transforma e que se transforma no ato de ler poderá abrir junto ao indivíduo-leitor e muitas comunidades de leitura uma propedêutica de massas.

O poema-praxis convoca essa propedêutica. É um compromisso coletivo. ${ }^{177}$

Nesse trecho, Chamie opõe leitura das massas a consciência coletiva de leitura. Diz que a leitura das massas não importa no sentido da quantidade, pois o que efetivamente importa é a consciência coletiva da leitura, ou seja, a qualidade desta, ou a leitura feita da perspectiva de uma posição política coletiva realizada como transformação social. Nesse sentido, ele tenta dar conta da questão do público, deixando implícito que não é a quantidade dos leitores que importa, mas a qualidade político-estética da leitura que é feita, ainda que por uma minoria. Essa minoria é representada, provavelmente, pelos próprios praticantes de praxis, que 
escrevem poesia orientados por essa "consciência coletiva de leitura". Em contraposição à poesia concreta:

Um poema-praxis não é coisa, é energia. ${ }^{178}$

Ou seja, implicitamente, o autor opõe a concepção de prática como trabalho ou dinamismo transformador à concepção objetual da poesia concreta, em que o poema tem existência autônoma, como um objeto a mais entre as coisas existentes, como falava Haroldo de Campos sobre os objetos naturais.

Dois ensaios publicados em 1964 tentam mostrar como praxis, segundo Mário Chamie, supera o concretismo e o neoconcretismo. Mais especificamente, o primeiro ensaio, "Poema-praxis: um evento revolucionário", tenta demonstrar como a geração de 1945, o movimento concreto e o neoconcretismo se posicionaram diante do movimento de 1922 e qual a relação entre eles:

A verdade, porém, é que o concretismo, tanto quanto a geração de 45 , não se deu conta do fato que resume a importância e o significado histórico da revolucionária poesia modernista. É o fato de que o modernismo - através da sua "permanente liberdade de pesquisa" - tornou-se obsoleto e perempto todo rigorismo que se baseasse em leis fixas e formulações condicionantes a priori. Assim, se o movimento de 22 desintegrou e aniquilou os cânones da retórica tradicional que alimentava uma poesia formalmente velha, disfarçada nas sucessões novas de "ismos" como romantismo, parnasianismo, também aniquilou, por antecipação, os cânones do que viria a ser uma retórica contemporânea com suas leis extraídas de outras artes e de teorias científicas. ${ }^{179}$

Chamie identifica a poesia concreta com um neoparnasianismo. Lendo seu texto lembra-se que o modernismo atacou o passadismo parnasiano.

Sobre o neoconcretismo, escreve o autor:

Contra essa exacerbação mecanicista e esse academismo atualizado (diferente do academismo de 45) surgiu o movimento neoconcreto.

\footnotetext{
178 Idem, ibidem.

179 Idem, p. 105.
} 
Se este último movimento fez justa crítica ao racionalismo concretista, não o soube fazer segundo a dinâmica específica de 22 . Talvez por incorrer no mesmo equívoco de base que vinha desde a geração de 45 . Vale dizer, se essa geração compreendia a evolução de formas conforme um precário jogo dialético entre atitude romântica e atitude clássica, o neoconcretismo passou a compreendê-la, mudando apenas os fatores do jogo: ao invés dos conceitos gastos de classicismo e romantismo, adotou a disputa bipolar entre o que é orgânico e o que é mecânico. ${ }^{180}$

No texto, Chamie traça um histórico dos movimentos anteriores, classificando suas práticas como ineficazes. Detectanto os problemas das vanguardas anteriores e definindo-os como um "equívoco", que consistiria na explicação da série literária por meio de oposições simples e precárias, como "romântico" × "clássico", Chamie pode afirmar que o neoconcretismo muda os termos da oposição, mas não a própria oposição. Assim, com sua "vanguarda nova", a instauração praxis deve superar as manifestações anteriores, sem repetir seus problemas.

Sendo assim:

A poesia surgiu, no Brasil, enfrentando a situação anterior descrita. O seu ponto de partida fundamental foi a consciência da realidade brasileira, em dois níveis: a) um histórico; b) outro autonomamente instaurador. (...)

O ponto de partida da poesia praxis poderia ser o mapa de identificação aberto e proposto por 22. Só não o é porque ela fecha o ciclo do modernismo, ao superar os movimentos que, na tentativa de retomar o diálogo de 22, incidiram num comportamento que o próprio modernismo invalidou, quer enquanto perspectiva sobre o passado, quer enquanto perspectiva sobre o futuro. ${ }^{181}$

Mais à frente, acrescenta o autor sobre a poesia praxis:

(...) Ela capta uma dinâmica e uma velocidade de circunstâncias e projetos que densificam e intensificam a realidade brasileira. Ela caracteriza a mudança de uma consciência identificadora para uma consciência transformadora que introduz fatores de

\footnotetext{
180 Idem, ibidem.

${ }^{181}$ Idem, p.106, 109.
} 
compreensão sem os quais o ato de escrever, hoje no Brasil, corre o risco de ser eterno e demissionário esforço de contemporaneidade internacional. (...)

A poesia praxis, ao colocar em crise o movimento de 22 , procura dimensionar um aprofundamento de inter-relações. O passo decisivo que dá é, portanto, o de não atuar sobre temas. Propõe-se levantar problemas. ${ }^{182}$

Observa-se que, como propõe o título do ensaio, praxis promete um "evento revolucionário", uma transformação radical no panorama contemporâneo da vanguarda. Mais uma vez, fica visível que a idéia de "revolução", presente nos anos 1960, é a pedra de toque da teoria praxis.

Em "Instauração praxis: vanguarda nova", o lema é superação. Praxis é a tentativa de superar a idéia de escola e movimento, no plano internacional, e as polarizações, no plano nacional. Assim:

Sem a preocupação de retomar qualquer diálogo com 22 e julgando mesmo que o que importa é superá-lo, a instauração praxis incorpora uma perspectiva do futuro sobre o presente e não contrapõe um stock de regras aos repertórios de movimentos anteriores. Nela, tudo se resolve em termos de uma consciência anti-canônica, em que a opção individual levanta as suas áreas e as resolve em dados-feitos originais de linguagem. ${ }^{183}$

Supondo que 1922 esteja superado ou que se deva superá-lo, praxis rejeita a idéia de escola e movimento, apesar de constituir mais um deles. Organiza uma teoria, rompe com esquemas tidos como tradicionais, ultrapassados e, como uma típica vanguarda, projeta o futuro no presente, lembrando aqui a citação de Enzensberger:

O "avançar" da vanguarda quer realizar simultaneamente o futuro no presente, antecipar-se ao curso da história. ${ }^{184}$

Em "O texto praxis no contexto vivo" (Plataforma Um), também de 1964, Chamie define o lugar da palavra no texto praxis:

\footnotetext{
182 Idem, p.109-111.

${ }^{183}$ Idem, p.121. Grifos nossos.

${ }^{184}$ Art. cit., p.93.
} 
A palavra, portanto, para o texto praxis não é mero componente. Não se reifica. Integra-se no contexto vivo. É um dado de civilização. Sua energia e destino de uso a colocaram dentro do mesmo processo que leva o desenho industrial ao produto; a planta ao conjunto arquitetônico; o míssil ao movimento no espaço. ${ }^{185}$

Segundo Chamie, a poesia concreta reifica a palavra, pois a matematização cerebral que abole toda expressão da subjetividade e toda representação realista implica operar o poema com elementos abstratos da língua ou da estrutura lingüística. Na sua formulação, os elementos da poesia praxis são extraídos de campos semânticos sociais em que a palavra usada no poema tem vários valores de uso, ou seja, a palavra não é abstração, como elemento da estrutura lingüística apenas, mas é enunciado feito numa situação particular, evidenciando justamente por isso várias contradições de seus usos como várias posições sociais. Nesse sentido, a crítica que Chamie faz à poesia concreta implica a idéia geral de que a poesia praxis trabalha com enunciados e a poesia concreta trabalha com frases ou termos abstratos. Assim, Chamie reintroduz a questão semântica na determinação da forma poética, coisa que os poetas concretos não fazem, apesar de falarem do "salto conteudístico-semântico-participante", porque sua concepção de linguagem é a da lingüística da língua, não a da lingüística da fala, como é o caso de Chamie, em cujos textos se pode observar o uso de idéias marxistas que lhe permitem pensar os usos da palavra.

Vale notar ainda que:

Hoje, não interessa falar em crise do poema; o importante é reconhecer a crise do próprio ato de escrever e a necessidade de instaurar novos programas de texto. Não se trata sequer de crise literária. ${ }^{186}$

Mário Chamie, como observou Cassiano Ricardo, "coloca a crise em outros termos; vai situá-la no próprio ato de escrever. Embora não o explique, parece tratar-se de 'transe de fazer', transição para outro fazer. Uma passagem de

\footnotetext{
${ }^{185}$ Instauração praxis, v.I, cit., p.131.

${ }^{186}$ Idem, ibidem.
} 
'representação' para 'expressão', de 'expressão' para 'levantamento'. Mesmo assim, direi, é uma crise literária". ${ }^{187}$

O ensaio "Praxis: quase balanço e perspectiva" (1965) avalia a produção praxis, suas conquistas e avanços diante da situação contemporânea:

(...) Pusemos o contexto numa espécie de parêntese fenomenológico para levantarlhe a mera reprodução contemporânea e mecânica de um universo estatuído e que haveria nele de atual/atuante, de típico segundo suas condições peculiares de exteriorização. Levantamos, assim, modos e fatores centrais que poderiam vetorializar os processos de uma comunidade. (...)

Transformamos o leitor em co-autor e incorporamos no ato de compor um poema a noção de trabalho que pertence menos ao poeta que à coletividade. Tanto é assim que o leitor poderá manipular e mobilizar os signos de nossos textos não só como quem repete o ato de compor mas como quem os toma por pré-textos para a produção de novos poemas. Vale dizer: na mesma medida em que em nosso contexto tecnológico uma matéria-prima se transforma em produto e este detona uma consciência dinâmica de uso, os nossos poemas e textos abrem a possibilidade de uma leitura ativa e produtora. Nosso projeto, portanto, é o projeto do próprio contexto. ${ }^{188}$

Aqui aparece mais claramente a idéia de participação do leitor, o qual pode manipular e mobilizar os signos dos textos praxis, noção, aliás, já proposta nas poesias concreta e neoconcreta. Vale notar que o autor compara o processo de "leitura produtiva" ao contexto tecnológico que transforma matéria-prima em produto. O mesmo poderá fazer o leitor dos textos praxis. Sobre isso, observou Cassiano Ricardo:

O poema é objeto de uso, mas a condição que estabelece para seu uso (o leitor tirar dele quantos poemas queira) não parece ocorrer, na prática.

Até à presente data, pelo menos, a hipótese não ocorreu; ao que eu saiba, nenhum leitor se fez co-autor. (...)

187 Poesia praxis e 22, cit, p.25.

${ }^{188}$ Cf. CHAMIE, Mário. In: Instauração praxis, v.I, cit, p.149-150. Grifos nossos. 
Não há mal nenhum nisso. $\mathrm{O}$ mérito do dado-feito continua intacto. Apenas o processamento proposto poderá então incorrer numa certa carência dialética, contrária a praxis. $^{189}$

No mesmo ensaio, Chamie critica o que chama de "culto da tradição como continuidade insuperável" e "mito do paralelismo na evolução de formas". 190 Os movimentos anteriores a praxis, segundo ele, foram uma disputa de tradições. Compara romantismo, parnasianismo e simbolismo, e questiona: "O que um diante do outro representa, do ponto de vista de uma evolução formal? Praticamente nada. São tópicos de um mesmo universo: de um todo dentro do qual se acionam identificados, enquanto processamento, com uma mesma nomenclatura básica". ${ }^{191}$

Sendo assim:

O que estamos mostrando é que entre a tradição e o paralelismo, a crítica aos processos de cumulação encontrou o seu equacionamento na necessidade de uma praxis instauradora de uma tradição nova. De uma tradição anti-literária. Foi e é o que estamos fazendo. ${ }^{192}$

Os resultados de praxis são apontados numa relação de livros, que vai de Lavra Lavra, de Mário Chamie, a Dardará, de O. C. Louzada Filho.

Sobre Lavra Lavra, escreveu Chamie:

Recolocou-se, através desse livro, a palavra numa tríplice e virtual função semiótica: semântica, sintática e pragmática. Noções inéditas de espaço em preto, geometrismo móvel, suporte interno de significados... ${ }^{193}$

Além do lançamento de outros livros de autores-praxis, Mário Chamie destaca o reconhecimento nacional e internacional de Praxis:

$\mathrm{Na}$ França, a revista Les Lettres abre, nos números 32/3, suas páginas aos nossos textos críticos e poemas... Na Itália, segundo recente depoimento do poeta Edoardo

\footnotetext{
${ }^{189}$ Op. cit., p.47.

${ }^{190}$ In: Instauração praxis. São Paulo, Quíron, 1974, v.II, p.151.

${ }^{191}$ Idem, p. 152.

192 Idem, p. 157.

193 Idem, p. 159.
} 
Sanguineti, os dois próximos números da revista Marcatrè trarão textos praxis traduzidos e comentados... ${ }^{194}$

\section{No Brasil,}

Manuel Bandeira, na última edição da Apresentação da Poesia Brasileira (Edições de Ouro), situa-nos às páginas 178/9. Afrânio Coutinho, na segunda edição de Introdução à Literatura no Brasil, faz a mesma coisa à página 296. (...) ${ }^{195}$

A instauração praxis tem interesse, tal como a poesia concreta, de evidenciar que é reconhecida; para tanto, o aval da crítica internacional é novamente importante: "mais uma vez a Europa se curvou frente ao Brasil etc."

"Incursão em curso" (1969) anuncia uma nova fase em praxis:

(...) praxis não se define antes ou ao lado dos acontecimentos, dos fatos que dão fisionomia ao nosso contexto, à nossa situação. Define-se com eles. (...)

Praxis procura estar dentro dos acontecimentos. (...)

A didática nova que praxis instaura, em última análise, é essa: ensina autor e leitor a executarem, no seu dia-a-dia, um projeto de transformação da realidade. E quem transforma, atua numa perspectiva do futuro; incorpora-a no seu fazer, tornando o futuro o seu fato cotidiano. (...)

Pretendemos nos próximos números bimestrais incursionar por outros setores criativos. Nesses outros setores o processamento do projeto viverá a sua mesma exemplaridade. Comportamento coletivo, nossa instauração não se limita a linguagem escrita mas a todos os prospectos de produção que informam e vitalizam o CONTEXTO. ${ }^{196}$

Essa "nova" fase de praxis anunciada no texto acima é acompanhada do poema Pelé, pastor do povo, de Mário Chamie, que se baseia nos mil gols do jogador. O que se nota nessa fase de praxis, se comparada aos poemas de Lavra Lavra, por exemplo, é que não se fala de uma situação, mas de um acontecimento que é atualização:

\footnotetext{
194 Idem, p. 162.

195 Idem, p. 164.

${ }^{196}$ Idem, p. 169-173.
} 


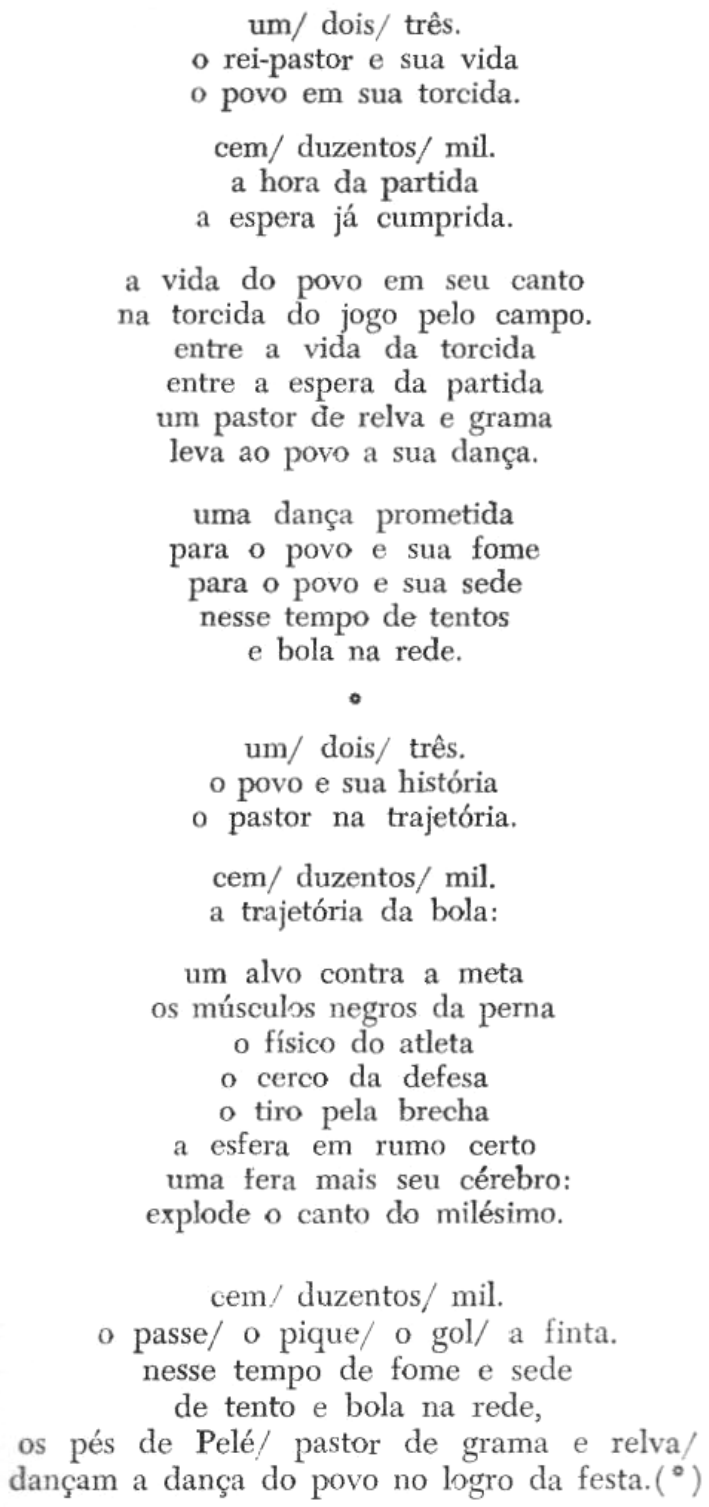

\section{"Plataforma dois" (1965/1966) propõe "um novo momento dialético":}

Em permanente fazer, o esforço praxis se abre nesse momento ao trabalho de produzir, na demanda de um estágio maior de consciência e de comunicação de novos dados. Praxis agora: outro alcance do por-fazer, para a crítica criativa de tudo o que nos situa.

Os tópicos do que nos situa: a massificação dirigida como nunca; o surgimento de um estilo empresarial/administrativo nas relações entre indivíduos, grupos e estados; as 
ambigüidades ideológicas; a utilidade neutra de um progresso industrial que mantém um atraso social... ${ }^{197}$

O título do livro Indústria inclui tanto o "contexto" como os procedimentos de produção do objeto-livro e, ainda, da leitura como co-autoria dele. No caso, praxis transforma-se claramente no que seu próprio nome afirma: prática/ pragmática. Daí a referência às "enunciações”, pois o poema prevê, agora, o campo contraditório exposto pelo autor: massificação, estilo empresarial/administrativo, ambigüidades ideológicas.

Os poemas que acompanham esse texto propõem-se a mostrar algumas contradições desse "momento dialético", identificado pelo autor. Porém, é com o último texto-manifesto, “O textor”, posfácio do livro Indústria, de Mário Chamie, que se realiza uma teoria a respeito, embora pouco esclarecedora:

Textor: a linguagem que levanta, dialética e criativamente contradições significativas de uma dada área, através de fragmentos completos de dicção. (...)

O textor não se opõe ao poema e a outros tipos de texto. Impõe-se, apenas, acima de. E apesar de. (...)

Então: autor + leitor + texto $=$ textor. $^{198}$

O livro Indústria é dado como representante dessa teoria:

Indústria: uma ampla área composta de intrassignos. Um supersigno já pelo título que, no seu corpo significante, resume atividade material, processo tecnológico, artimanhas, trama política, chantagem econômica, carência e enredo ideológico (tanto do povo enredado quanto das forças e poderes que o enredam). Está no título e no livro: a condição urbana que distancia as classes, no plano maior das relações de produção e consumo.

(...) antes, partíamos da palavra. Interferíamos pela palavra. Era o início de uma inédita consciência de leitura. (...)

Agora, partimos de enunciações... ${ }^{199}$

\footnotetext{
${ }^{197}$ Idem, p. 179.

198 Idem, p.264.

${ }^{199}$ Idem, p.261-262.
} 


\section{MÁRIO CHAMIE}

dois fragmentos de INDUSTRIA

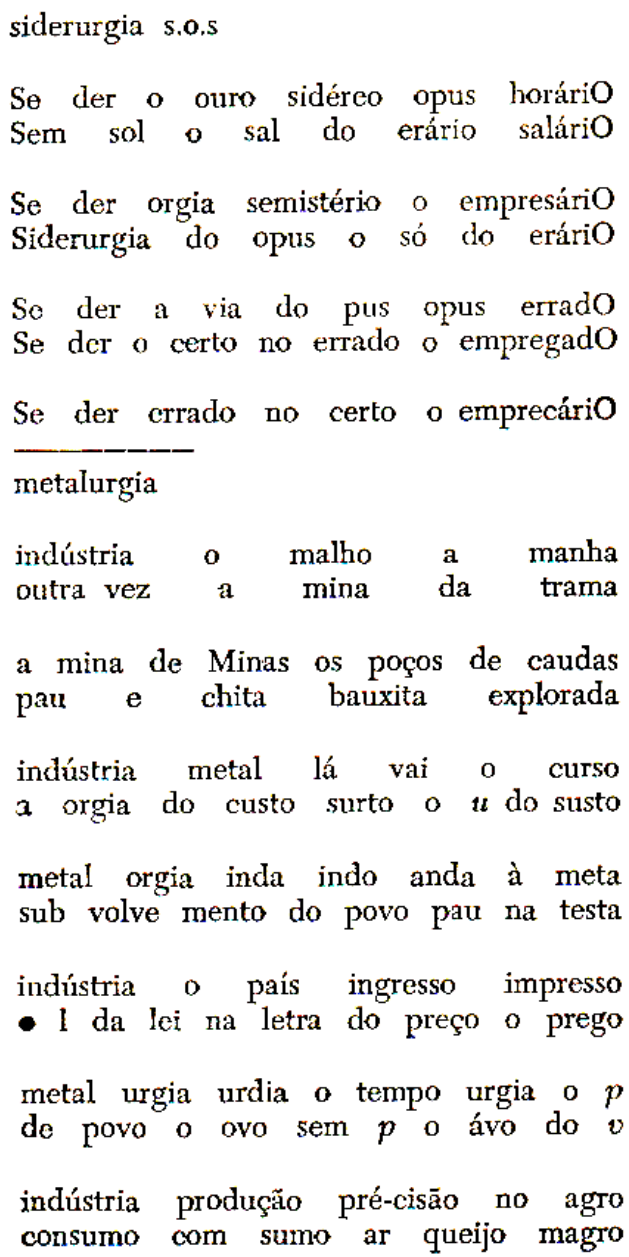

\section{MOVIMENTO HIDRAUULICO}

(poema-praxis)

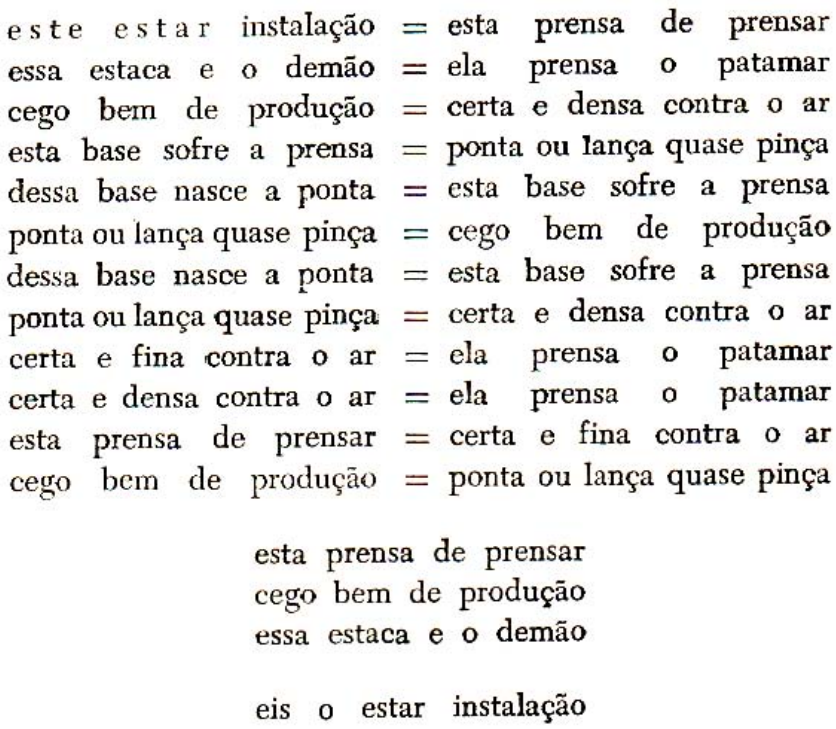

Nesses dois poemas de Indústria nota-se uma outra forma de espacialização que os distingue dos poemas de Lavra Lavra. O espaço em preto põe a nu todos os elementos de uma construção: o fonema, o monema e o sintagma. Em movimento hidráulico, as enunciações sumárias ou sintagmas ou ainda dictemas, como definiu o poeta ("este estar instalação", "esta prensa de prensar" etc.), tornam-se o centro gerador do poema. Esses sintagmas são repetidos com exaustão, dando a idéia do próprio movimento repetitivo e mecânico da indústria. 
O fato de algumas vanguardas, como a poesia concreta, terem incorporado elementos da comunicação de massa fez que, embora seu consumo fosse restrito a poucos, sua diluição fosse rápida, porque esta já estava dada na própria comunicação de massa que incorporou. A poesia perdeu, no caso, a função de poesia tradicional, principalmente porque a leitura de qualquer poema concreto esgota, já na primeira vez em que é feita, a regra que o ordena: a combinação/ permutação de seus elementos. Provavelmente, o leitor pode fazer novos jogos com seus elementos no sentido "verbivocovisual" que propõe o projeto, mas sempre com a mesma regra, o que dá a essa poesia, também, certo caráter do jogo com trocadilhos que foi lembrado por críticos como Antonio Candido. Obviamente, o efeito decorre da coerência rigorosa do projeto concreto, que é avesso a toda e qualquer "profundidade", ou seja, à metáfora e à conotação, que se abrem sempre para novas interpretações, como acontece na poesia modernista e moderna dos melhores poetas brasileiros. Por exemplo, quando se lê "Quando nasci, um anjo torto...", as possibilidades de leitura são abertas para além da afirmação de que "anjo torto" significa, por exemplo, "diabo", "malvado", "gauche" ou "de má sorte". No sistema poético de Drummond, a expressão também pode significar, por exemplo, a tradição latifundiária de sua família mineira. Aliás, é Drummond quem afirma:

(...) eu acho as vanguardas uma coisa puramente superficial, e que não deixa traço na vida cultural brasileira. $\mathrm{O}$ vanguardista é um homem que rompe com todos os cânones, procura fazer uma coisa de estardalhaço, e que passa com maior rapidez possível. Hoje, acho que ninguém fala mais em poesia concreta, em poesia praxis, nessas coisas. Elas foram realmente curiosas na ocasião em que apareceram. Eles se gabam muito historicamente que na Suíça foram citados, na Alemanha e outros países da Europa, mas o fato é o seguinte, não fica uma poesia, eu estou falando da vanguarda poética, uma poesia que não tenha raízes profundas na sensibilidade humana e na consciência artística. ${ }^{200}$

\footnotetext{
200 "Uma prosa (inédita) com Carlos Drummond de Andrade". Entrevista concedida em 1984. Caros Amigos, n.29, p.14, ago. 1999 .
} 
Os representantes desses movimentos, especialmente do concretismo e da praxis, afirmam sua influência no cinema e, em especial, na música popular brasileira. No caso de praxis, Mário Chamie afirma insistentemente a incorporação das idéias praxis em diferentes setores da comunicação:

Mas suas conquistas até aqui, já incorporadas no contexto brasileiro como uma força de projeto de transformação, são assimiladas por jovens e velhos em diferentes setores de comunicação. Do cinema à publicidade, da publicidade à música popular isso ocorre. Sirva de exemplo a composição musical Construção (1971), de Chico Buarque de Holanda, toda ela calcada no sistema de topografia semântica e de mobilidade intercomunicante das palavras, introduzido por praxis. ${ }^{201}$

Praxis também estabeleceu diálogo com as teorias que estavam em discussão na época:

A perspectiva praxis era uma autêntica vanguarda. Convocava os valores da palavra como comunicação profunda, constantes da literatura brasileira, estudos e conclusões da moderna lingüística e estética, como de Cassirer, Urban, Susanne Langer, Dorfles, além de testemunhos de pensadores e estetas como Sartre e Dufrenne. Antes de tudo, abria amplas e múltiplas perspectivas no campo da cultura, permitindo a integração consciente de todos os setores de atividade artística e cultural. ${ }^{202}$

Nota-se, porém, que em praxis não há a adoção de um paideuma, como na poesia concreta. Mário Chamie procura sua própria teoria, mesmo que complexa e hermética, sem citar diretamente autores e obras.

\footnotetext{
201 "Poesia e instauração praxis", p.232. Mais detalhadamente em "Poesia ao pé da letra no festival" (Cf. os dois artigos in Instauração praxis, cit., v.II, p.109-111).

${ }^{202}$ Cf. CABRAL, Antônio Carlos. "Poema-praxis e atitude central". O Estado de S. Paulo, 27 jun. 1964. Suplemento Literário, p.6.
} 


\subsection{Poema-Processo}

O ano de 1967 marca a abertura da exposição Nova Objetividade Brasileira (em abril, no MAM, do Rio de Janeiro), que reúne a diversificação de experimentações de artistas de vanguarda, muitos vindos do neoconcretismo. A proposta é renovar e retomar objetos e ambientes, "agora acrescidos de uma perspectiva crítica antes inexistente, através da incorporação da violência viva em nossa realidade: as manifestações ambientais de Hélio Oiticica (como a Tropicália, de 1967, e a Apocalipopótese, de 1968) e as experiências sensoriais de Lígia Clark (a exemplo da sua A Casa é o Corpo, de 1968) destacam-se como abertura de rumos para as pesquisas mais atuais na arte pobre, do detrito e do lixo". ${ }^{203}$

Em dezembro do mesmo ano, surge o poema-processo, último movimento organizado na vanguarda poética brasileira com teoria embasando a produção. Seu lançamento ocorreu simultaneamente no Rio de Janeiro (Expo-ESDI) e em Natal, Rio Grande do Norte (Sobradinho). Como na poesia concreta, neoconcreta e praxis, em que alguns assumem mais a elaboração de teorias e outros dedicam-se à produção de poemas, o poema-processo tem os poetas Wlademir Dias-Pino, Álvaro de Sá e Moacy Cirne como principais teóricos, e Neide de Sá se destaca com obras.

Sobre a relação entre teoria e prática no poema-processo, seus representantes defendem:

O processo é um movimento em aberto. Não tem líder nem teóricos. A teoria é uma especialização assim como o estilo. Somos pelo global, o coletivo. Com isto quero dizer que qualquer tentativa teorizante dos que participam no movimento é pura necessidade de mostrar que o que falta é uma crítica visual para poemas igualmente visuais. (...)

O Poema Processo não quer usar das técnicas modernas: ele é a técnica. ${ }^{204}$

\footnotetext{
${ }^{203}$ PONTUAL, Roberto. "A arte próxima: resistência, recomeço e/ou remoção?". Revista de Cultura Vozes, ano 64, n.2, p.29, mar. 1970.

204 "O Poema/Processo não acredita em L.S.D. Entrevista a João Felício dos Santos". In: DIAS-PINO, Wladimir. Processo: linguagem e comunicação, Petrópolis, Vozes, 1971, não pag.
} 
A principal fonte de consulta a textos e práticas do poema-processo é o livro Processo: linguagem e comunicação, ${ }^{205}$ de Wladimir Dias-Pino. Sua organização parece insólita: os textos, em geral lacônicos, são acompanhados de poemas que parecem seguir certa ordem cronológica, mas, em sua maioria, não são identificados com datas, não se podendo estabelecer uma correspondência cronológica, em que o poema teria sido feito antes da teoria ou vice-versa. Sendo assim, a análise procura seguir a ordem do livro.

O primeiro texto, intitulado "Proposição", foi publicado como manifesto no jornal $O$ Sol, em dezembro de $1967 .^{206}$ A preocupação com a civilização técnica e o consumo de massa da teoria da poesia concreta são retomados:

\author{
QUANTIDADE + QUALIDADE \\ SÓ O CONSUMO É LÓGICA. \\ CONSUMO IMEDIATO COMO ANTINOBREZA \\ FIM DA CIVILIZAÇÃO ARTESANAL (INDIVIDUALISTA) \\ SÓ O REPRODUTÍVEL ATENDE, NO MOMENTO EXATO, \\ ÀS NECESSIDADES DE COMUNICAÇÃO E INFORMAÇÃO \\ DAS MASSAS. \\ A MANIFESTAÇ̃̃O SERIAL E INDUSTRIAL DA \\ CIVILIZAÇ̃̃O TÉCNICA DE HOJE. ${ }^{207}$
}

Com base nesse raciocínio, procura-se uma forma útil:

FORMA ÚTIL

\author{
NOVAS POSSIBILIDADES PARA CADA MATERIAL \\ VISUALIZAÇ̃̃O DA ESTRUTURA/LEITURA DO
}

\footnotetext{
${ }^{205}$ É importante observar que o livro traz boa parte dos textos teóricos e poemas sem data. Sendo assim, fica difícil fazer uma análise que siga uma cronologia detalhada do movimento. Outro detalhe do livro é que não há paginação. Para melhor situar o leitor, pode-se dizer que há três partes: 1) documentos oficiais (textos); 2) documentos oficiais (fotos); e 3) anexo. Os documentos oficiais, grande parte na forma de esquemas muito resumidos, são acompanhados da produção poética. Juntos dão uma idéia da seqüência evolutiva do movimento.

${ }^{206}$ A informação é de Gilberto Mendonça Teles (Vanguarda européia e modernismo brasileiro. Rio de Janeiro, Record, 1987, p.422-423).

${ }^{207}$ In Processo: linguagem e comunicação, cit.
} 
PROCESSO.

NÍVEL TÉCNICO IGUAL A EVOLUÇÃO: O DESUSO DO

OBJETO ÚNICO

(...)

POESIA PARA SER VISTA E SEM PALAVRAS (SEMIÓTICA). ${ }^{208}$

O poema-processo, apesar de propor mais um jogo gráfico do que plástico, está muito próximo da poesia concreta no que concerne à proposta formal, pois ambos privilegiam a visualidade da estrutura e a "forma útil", proposta na última como "objeto útil". Os únicos elementos que chamam a atenção são a "leitura do processo", que é praxis, e a poesia "sem palavras", que é arte plástica, parecendo que o processo tenta a síntese de concretismo, neoconcretismo e praxis. Os dois conceitos podem apontar para a "nova poesia" do grupo, mas ainda não foram definidos.

Em "Processo - leitura do projeto", texto mais explicativo, procura-se definir a noção de "processo":

1. Processo: desencadeamento crítico de estruturas sempre novas.

Processo é a relação dinâmica necessária que existe entre diversas estruturas ou os componentes de uma dada estrutura, constituindo-se na concretização do contínuo-espaçotempo: movimento $=$ operar soluções. $(. .$.

Assim o relacionamento fundamental existente através do processo é que os diversos elementos afetam-se, isto é, um elemento é afetado pelo anterior que lhe antecedeu e afetara o posterior que lhe sucede. É neste ponto que se diferencia do interrelacionamento estrutural onde todos os elementos interagem-se estaticamente. ${ }^{209}$

A relação dos "diversos elementos" é definida como combinatória, nada tendo de propriamente "novo", pois já foi feita pela poesia concreta. A diferença aparente é a proposta do inter-relacionamento dinâmico que inclui o procedimento praxis e critica o "estático", que praxis já tinha atribuído ao concretismo.

\footnotetext{
${ }^{208}$ Idem.

${ }^{209}$ Idem.
} 
Definido o "processo", busca-se explicar a escolha de "poema/processo" e não "poesia/processo". O que importa no uso do termo "poema" é a "estrutura" que está vinculada à sua definição:

\section{Poema/processo: visualização da funcionalidade/consumo.}

Não há poesia/processo. O que há é poema/processo, porque o que é produto é o poema. Quem encerra o processo é o poema. O movimento ou a participação criativa é que leva a estrutura (matriz) à condição de processo. O processo do poeta é individualista, e o que interessa coletivamente é o processo do poema.

Poema/processo é aquele que, a cada nova experiência, inaugura processos informacionais. Essa informação pode ser estética ou não: o importante é que seja funcional e, portanto, consumida. O poema resolve-se por si mesmo, desencadeando-se (projeto), não necessitando de interpretação para a sua justificação. (...)

Dando a máxima importância à leitura do projeto do poema (e não mais à leitura alfabética), a palavra passa a ser dispensada, atingindo assim uma linguagem universal, embora seja de origem brasileira, desprendida de qualquer regionalismo, pretendendo ser universal não pelo sentido estritamente humanista, mas pelo sentido da funcionalidade. ${ }^{210}$

A citação é um tanto longa, mas traz novamente uma seqüência de idéias já vistas na teoria da poesia de vanguarda. Vale notar que, apesar de a idéia de "processo" e a escolha do termo "poema", e não "poesia", poderem sugerir algo novo, há muitos pontos de contato entre o poema-processo e a poesia concreta, tais como: a idéia de produzir informação para ser consumida e, portanto, de que o poema deva ser funcional; a convicção de que "o poema resolve-se por si mesmo", "não necessitando de interpretação para sua justificação"; e, por último, a afirmação de que a eliminação da palavra é a estratégia para se chegar a uma linguagem supostamente universal. Tal como na teoria da poesia concreta, o poema-processo também comunica estruturas.

Tanto em relação à poesia concreta quanto ao poema-processo, fica a observação: se o poema é consumido, espera-se algum tipo de interpretação. O que se faz com a informação do poema?

\footnotetext{
${ }^{210}$ Idem.
} 
Outro detalhe curioso do texto é a apresentação de um quadro didático que tenta diferenciar poema de poesia. O grupo atribui algumas características à poesia e ao poema: na primeira, no plano da leitura, estão a língua, a palavra, a tradução e o estilo, em contraposição ao segundo, em que estão a linguagem, o projeto, a versão e o contra-estilo. Já no plano da escritura, como propõe o texto, estão o regional, o individual, a representação, a personagem e o psicológico para a poesia, em contraposição ao universal, ao coletivo, à apresentação, à não-figuração e ao tecnológico para o poema. Observa-se que enquanto os movimentos de poesia de vanguarda vistos anteriormente não fazem distinção entre os termos, o poemaprocesso cria uma oposição inexistente nos conceitos tradicionais. O poema, sob o rótulo objeto, desprende-se da poesia e é caracterizado de acordo com as estratégias e procedimentos adotados no poema-processo. Cria-se um "poema” que não é mais literatura:

Pesquisa-se, hoje, novas grafias: na maioria dos casos, codificações para uso de condições visuais ou sonoras, aproveitando-se as dimensões físicas que o poema oferece. Essa autonomia do poema, não mais como mero suporte da poesia, transformou o poema em objeto: seu próprio canal.

O poema processo tanto é liberto da estrutura (da palavra) como do autor (psicológico).

O Poema/Processo é antiliteratura no sentido que a verdadeira mecânica procura o movimento sem atrito ou a eletricidade busca o isolante perfeito. ${ }^{211}$

Volta-se, então, à idéia de poema-objeto defendido pelo concretismo e pelo neoconcretismo, mas com a diferença de que os representantes de processo rejeitam o termo "poesia".

Em "Poema-Processo", outra idéia da teoria da poesia concreta é o “proceder matemático". O poema-processo é "antiliteratura"; "não é literatura modernista":

Poema-Processo: proceder matemático: leitura de resultados

\footnotetext{
${ }^{211}$ Idem.
} 
(...)

o P.P. não é literatura modernista

suas facilidades vêm do mundo moderno que a publicidade sabe explicar.

a programação mostra claramente a substituição da leitura pelo processo. ${ }^{212}$

Se a palavra já aparecia dispensada do poema em "Proposição", no texto "Código" ela parece encontrar um lugar:

Código: estágio didático do poema

(...)

* a palavra não é olhada como geradora de leitura.

*o sentido de aprendizagem que traz cada poema por ser novo é principalmente de leitura. $^{213}$

Os poemas que acompanham esse texto são de José Luiz Serafini e Neide Sá. Segundo o texto, "a palavra não é olhada como geradora de leitura". O aspecto geométrico não-figurativo desses poemas e a presença da chave léxica para deflagrar a interpretação de sentido da forma evidenciam o mesmo processo visto na última fase da poesia concreta nos poemas semióticos de Décio Pignatari. Desse ponto de vista, pode-se dizer que o poema-processo é uma continuação da poesia concreta. Esses poemas, de certa forma, são incompatíveis com a teoria do poemaprocesso: já no primeiro manifesto ${ }^{214}$, o grupo dispensa o uso das palavras no poema; no entanto, as palavras aparecem aqui dispostas numa chave léxica que, apesar de estabelecer significados arbitrários com as figuras, torna-se um instrumento decodificador do poema. Sendo assim, não faz muito sentido dizer que a palavra não tem a função de "geradora de leitura", como se pode observar nos poemas a seguir:

\footnotetext{
212 Idem.

${ }^{213}$ Idem.

${ }^{214}$ Ver nota 204.
} 


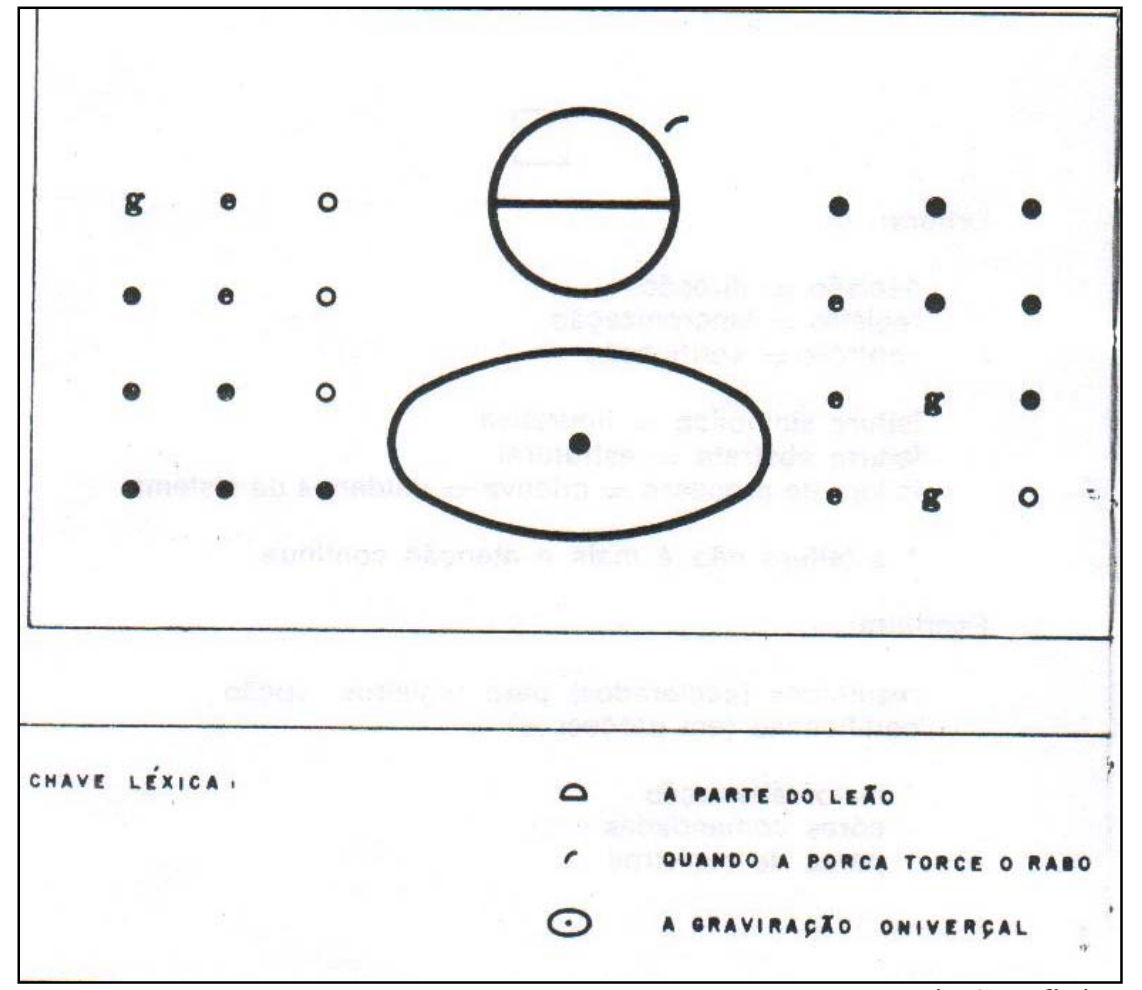

José Luiz Serafini

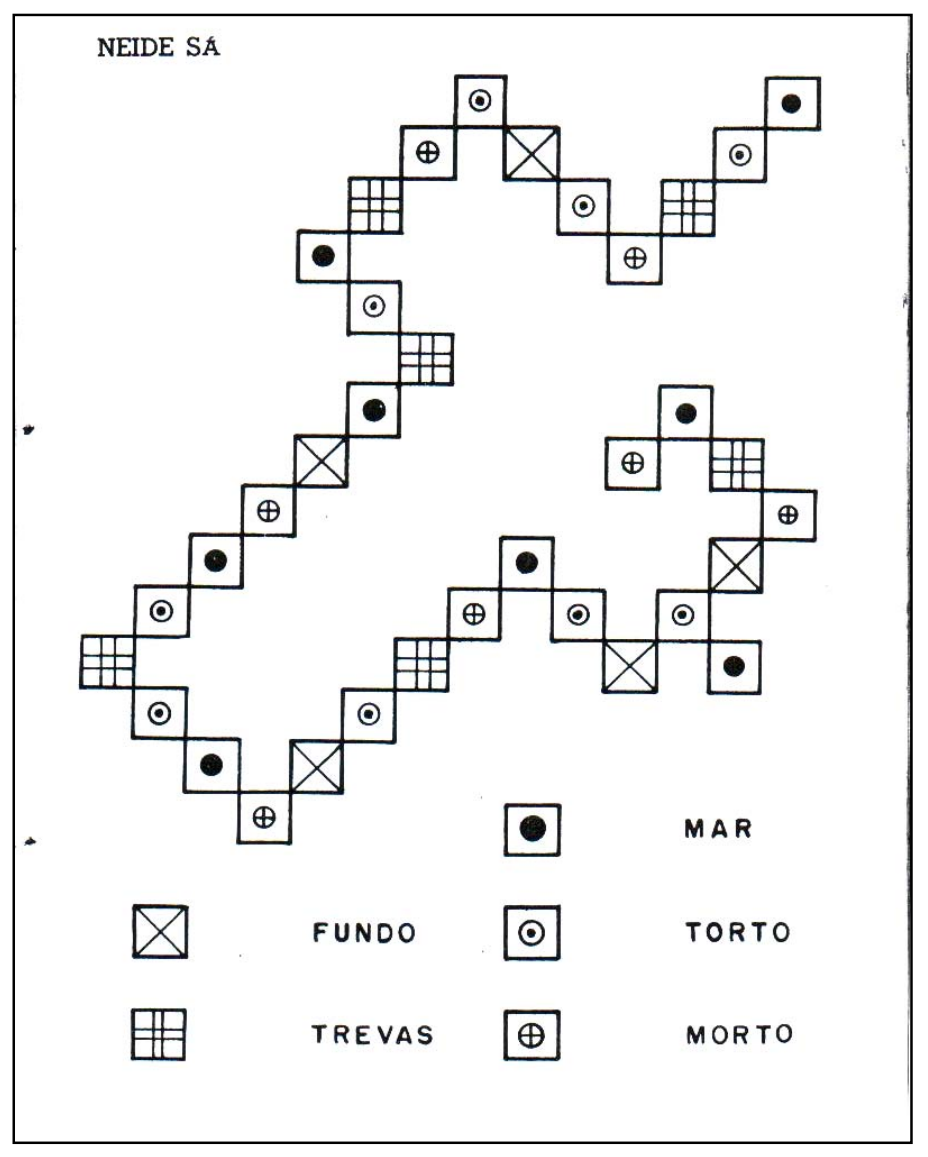


Em "Situação limite: separações e conseqüências", enfatiza-se novamente a separação entre poema e poesia:

O poema de processo, sob esta condição, não está preocupado com o "estado poético" como fator de maiores estudos, nem mesmo com a experimentação lingüística; mas tem o propósito de deixar bem claro que essa separação mostra, de maneira indiscutível, que o poema é físico - e até mesmo tátil - em sua visualidade gráfica, enquanto que a poesia é puramente abstrata. Tanto assim é que é comum a expressão "poesia de arquitetura". ${ }^{215}$

Nesse texto, o poema é assumido, na concepção de seus teóricos, como produto visual, concreto, que assume uma autonomia tal que pode atingir qualquer tipo de público:

(...) o poema - esse produto visual - pode ser testado coletivamente desde a sua funcionalidade até mesmo a sua plasticidade. (...)

O poema de processo já chegou mesmo a um nível autônomo em que pode ser manipulado e fornecer informações, independentemente do grau de cultura do consumidor. ${ }^{216}$

O texto "Versão", apresentado em tópicos, pode ser lido como a apresentação das principais características do poema-processo:

Versão: critério de valor: teste de funcionalidade do poema

(...)

* segunda função da versão: consumo

* exercícios de leitura: auto-superação

* prova que os processos não são conclusos

* a surpresa renovada em cada versão

* funcionalidade total

(...)

* Seqüências visuais. ${ }^{217}$

\footnotetext{
${ }^{215}$ Idem.

${ }^{216}$ Idem.

${ }^{217}$ Idem.
} 
A apresentação do texto em tópicos, impessoal e descomprometida, deixa apenas sugestões de leitura. A versão abrigaria todas as características lançadas anteriormente, entre as quais "o critério de valor: teste de funcionalidade do poema"; no caso, pode-se entender que a versão seria a produção de poemas com base em uma matriz. Sendo assim, o autor assumiria o papel de co-autor e, com isso, testaria o valor e a funcionalidade do poema, ligados diretamente ao consumo. Isso levaria "a estrutura à condição de processo".

Em "Matriz", a explicação segue o mesmo esquema de apresentação do texto anterior, dispondo as idéias em tópicos:

* : tele-comando/campo de possibilidades

* campo de possibilidades (de versões)

* acumuladora: previsão sobre conjuntos

* armazenamento de soluções: o exato

* memória móvel: sede-eixo ${ }^{218}$

Em seguida, "Série" é outra característica de processo. Consiste em:

estados sucessivos/

mutáveis - palavras/ permutações; / letras/ signos. ${ }^{219}$

A "série" é descrita como uma fórmula matemática, próxima à racionalização exposta na "matemática da composição" defendida pela teoria da poesia concreta:

comportamento: coeficiência de correlação

operação: o sentido global das séries

(...)

diagrama: lógica de decifrações

variável dinâmica: operações lógicas

soma dos favoráveis: freqüências relativas. ${ }^{220}$

\footnotetext{
${ }^{218}$ Idem.

${ }^{219}$ Idem.

${ }^{220}$ Idem.
} 
"Explosão tipográfica" é outro procedimento técnico adotado pelo poemaprocesso, em que o espaço em branco deixa de ser suporte e as letras tornam-se elementos de composição, como na poesia concreta:

Fragmentação da palavra:

O espaço branco do papel que como suporte tinha a função de arquiteturar o poema passou a entrar pelas palavras, fragmentando-as e possibilitando a

EXPLOSÃO TIPOGRÁFICA.

Palavras:

Novas possibilidades tipográficas/

Disposições gráficas ${ }^{221}$

"Poemas de animação" introduz no poema-processo a idéia de movimento, simultaneidade e continuidade:

Poemas sem palavras $=$ ânsia de visualizar a velocidade.

(...)

+ movimento como intensidade nova

+ construção formal unidade receptora simples

sinais simples: exercícios formais.

(...)

exercícios formais: levantamento de linguagem

cinematográficas. ${ }^{222}$

O poema-processo é uma espécie de híbrido concreto-praxis-cubo-futurista e, no caso, o que afirma do significado dos signos pode ser entendido como um reducionismo que tem implicações políticas muito discutíveis. Essa impessoalidade que pretende ter implica que o poeta ou programador de linguagem só pode trabalhar com as palavras em "estado de dicionário", quer dizer, implica que é preciso reduzir a significação da palavra à denotação. Essa redução trabalha com o pressuposto de que o significado denotativo é universal, ou seja, válido para todas as camadas do público. Supondo-se que isso possa ser válido, como se observa no

${ }^{221}$ Idem. 
dicionário, é preciso dizer, contudo, que as palavras da língua portuguesa só existem nos usos que produzem, porque são usos particulares, em situação, as inúmeras refrações e contradições da significação. Na sociedade capitalista, a linguagem é por definição contraditória, coisa que grandes poetas, como Drummond, sempre souberam muito bem. Por isso, o pressuposto de trabalhar com palavras em estado de dicionário é politicamente problemático porque apaga totalmente a questão da contradição social dos vários públicos leitores ou consumidores de poesia.

O texto segue com expressões soltas, como "noção de seguimento", "sensações visuais" etc. Nos poemas que acompanham esse texto, há uma seqüência evolutiva na qual se parte de uma situação visual inicial que, quadro a quadro, assume um dinamismo, num efeito de animação, como numa história em quadrinhos. A chave léxica também é retomada em alguns poemas; em outros, contrariando a proposta do movimento que atribuiu ao poema a não-figuração, as figuras aparecem, às vezes, acompanhadas de palavras que, numa seqüência, vão sofrendo alterações, dando dinamismo ao poema. Abandona-se a chave léxica numa busca de "independência do poema em relação à mensagem". Sendo assim, o poema-processo, fundamentado na teoria que afirma uma dinâmica de forma visuais puras, passa a apresentar uma especificidade que o distingue das demais manifestações da poesia de vanguarda brasileira, porém, aproxima-o dos procedimentos futuristas, como se pode notar na semelhança entre o poema de Celso Dias e a pintura futurista vórtice de Giacomo Balla, 1913-1914 (1993, 299):
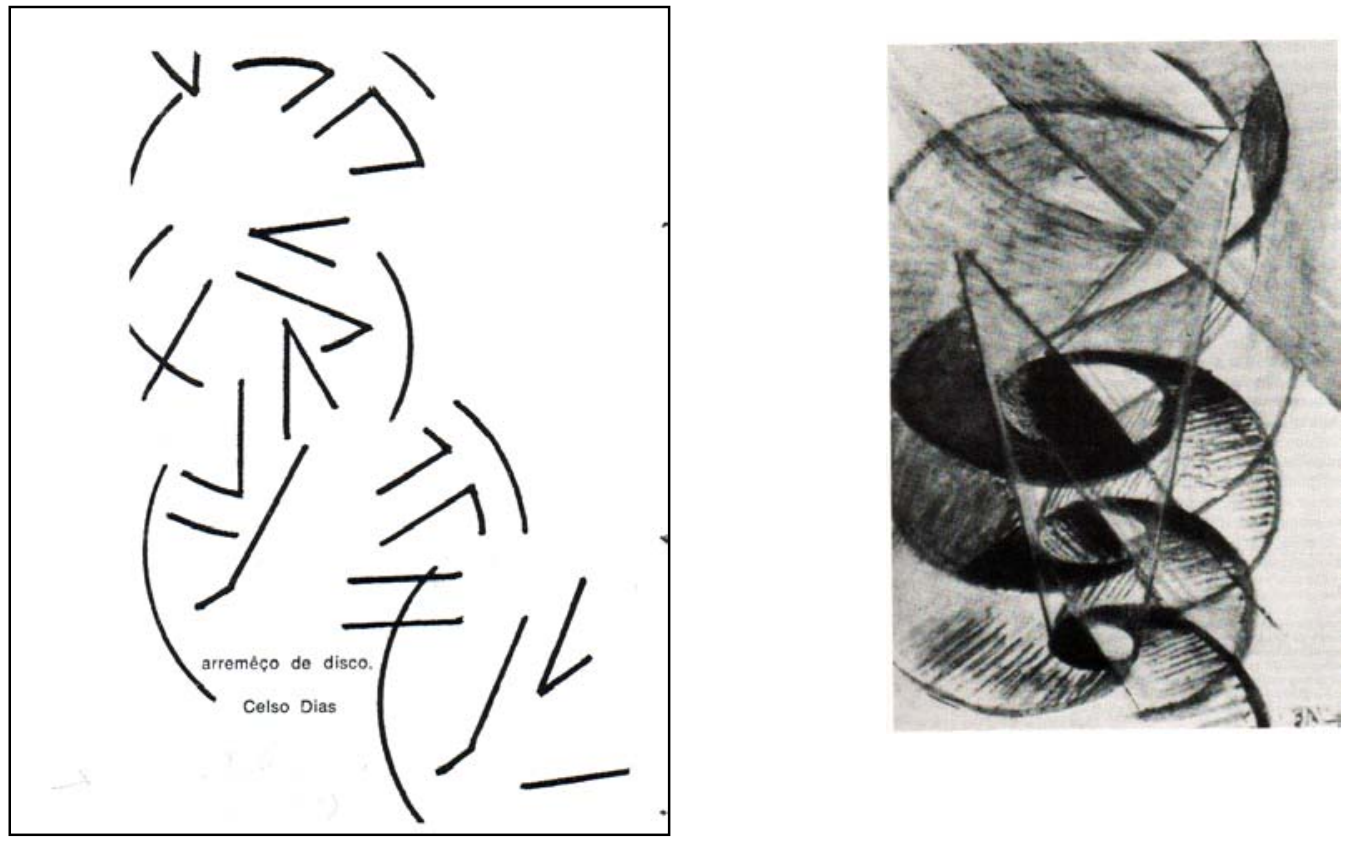


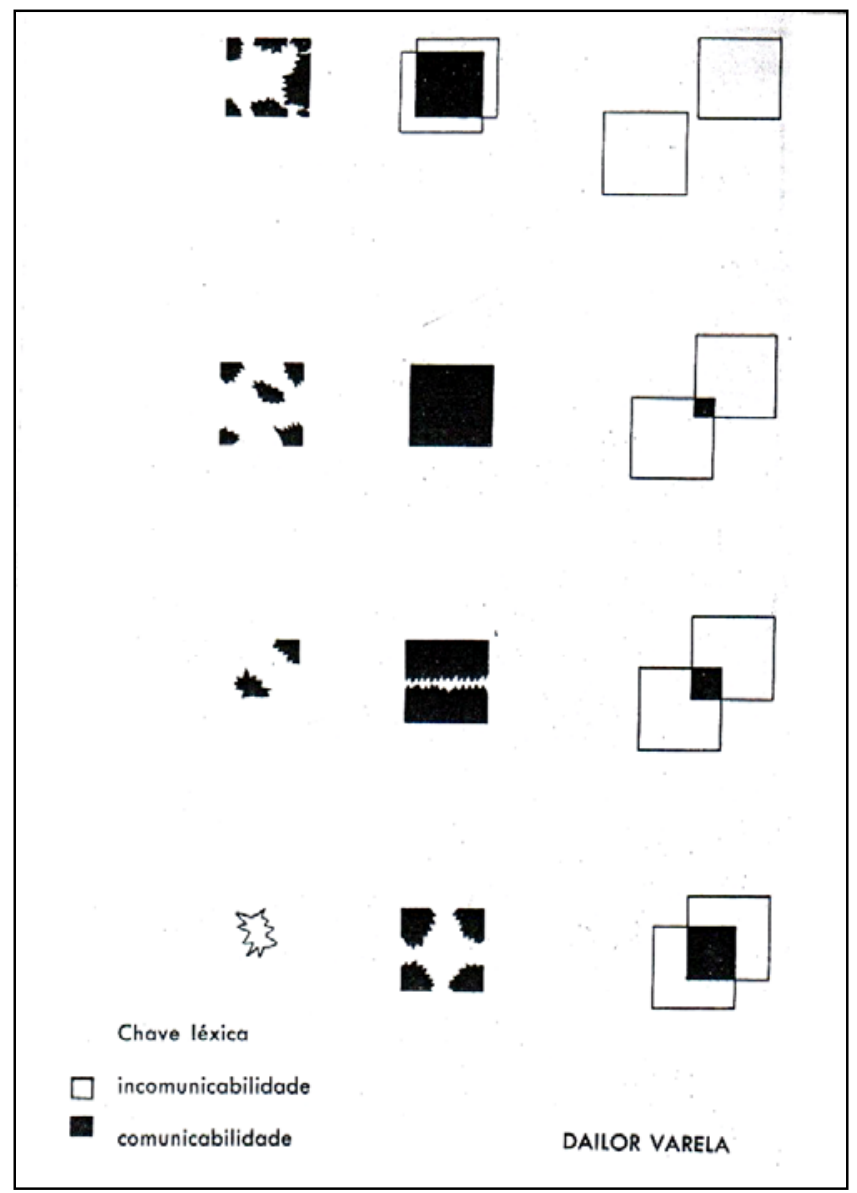

Sebastião G. Nunes

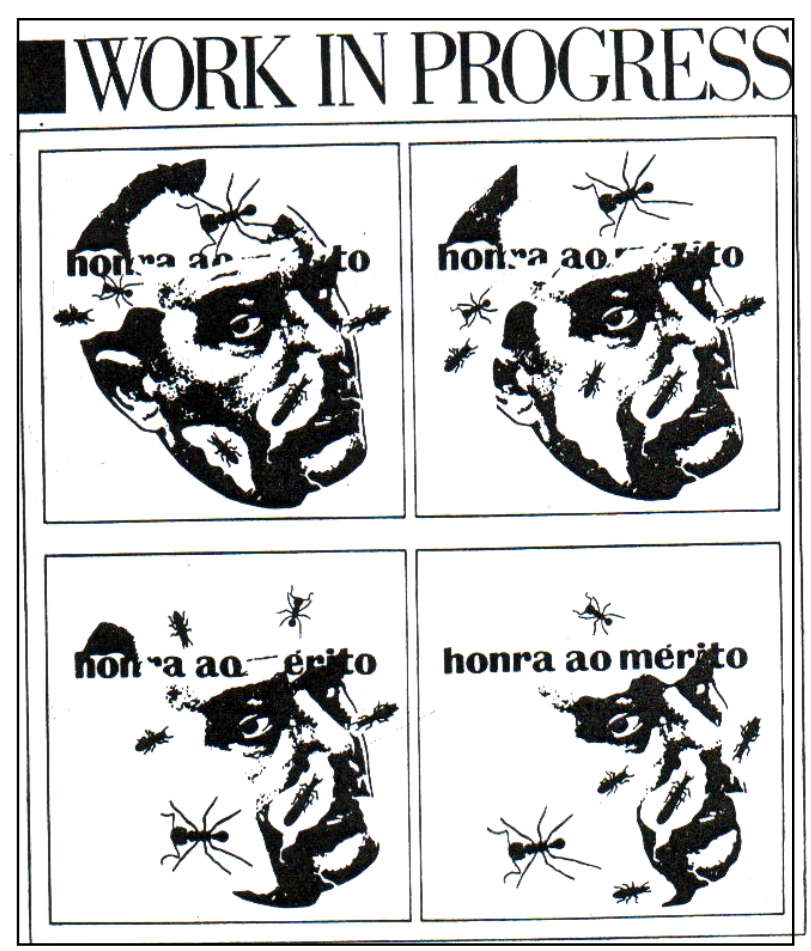


Em "Levantamento de linguagens", destaca-se a diversidade de linguagens:

Para que a integração fosse geral o poema procurou fazer o levantamento de todas as linguagens incorporando-o ao poema. Depois que o poeta descobriu que a palavra não é o único elemento identificador do poema, ele vem procurando novos instrumentos capazes de outras escrituras. ${ }^{223}$

Nesse texto, os autores de processo sugerem a invenção de um poema que integre todas as linguagens, mas os poemas que acompanham o texto não trazem novidades em relação aos já apresentados. Apenas se nota, neles, a inserção de sinais matemáticos:

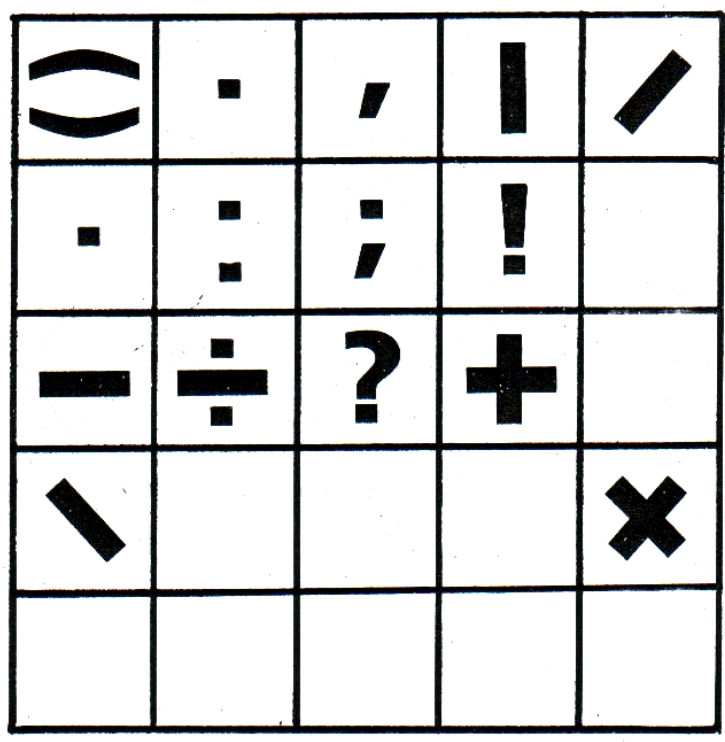

Talita Magger

O texto "Gráfico" abandona a idéia de "explosão tipográfica", vista anteriormente, e indica uma seqüência de procedimentos físicos e matemáticos que estariam ligados ao aspecto gráfico do poema-processo:

: geometrização; animação/

${ }^{223}$ Idem. 
circuitos: exercícios formados

GRÁFICO: poemas não tipográficos

indicação da direção de leitura

localizador de circuitos: faculdade física de abstração.

Circuito: gravador de condutores: geradores de sinais

Leitura de terminais; alturas desiguais: leitura de vértices.

Precisão: diagrama de decifração.

(...)

* poder-se-ia chamar a geometrização de redução ou concreção, para evitar maiores discussões, mas nunca como elemento só estrutural.

(...)

* O Poema-Processo não está preocupado em estudar especificamente o sinal, o símbolo, nem tão pouco o signo, ele quer é, de maneira clara, a programação do gráfico como elemento de leitura ou escritura. ${ }^{224}$

Pressupõe-se, com esse texto e os demais, que o movimento busca uma linguagem própria que substitua a figuração, a palavra, o signo, o símbolo convencionais. Sem uma correspondência certa entre significante e significado, o poema-processo opera num campo de elementos aleatórios: qualquer coisa pode representar qualquer coisa. Nesse sentido, o poema-processo parece estar muito próximo do abstracionismo, principalmente o geométrico, presente nas arte concreta e neoconcreta dos anos 1950. Deve-se lembrar que o "Abstracionismo coloca, pela primeira vez, com toda clareza, a autonomia entre arte e representação, que se delineia desde o Impressionismo". 225 É o que se pode notar no poema de P. J. Ribeiro, que se assemelha a um mapa e traz a seguinte observação: "Superada a figuração no poema qualquer mapa pode representar um cavalo de Tróia":

\footnotetext{
${ }^{224}$ Idem.

${ }^{225}$ Cf. COCCHIARALE, Fernando \& GEIGER, Anna Bela. Abstracionismo geométrico e informal: a vanguarda brasileira nos anos cinqüenta. Rio de Janeiro, Funarte/Instituto Nacional de Artes Plásticas, 1987, p.13-14.
} 


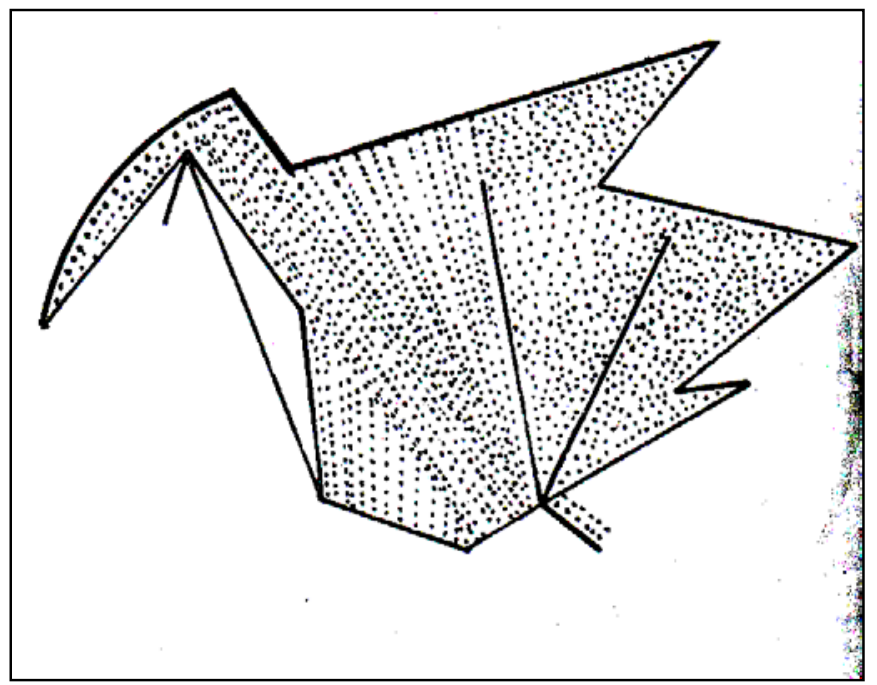

Relacionado ao mesmo texto "Gráfico", está o poema de Arabella Cunha, que traz uma frase sobreposta à foto de um braço:

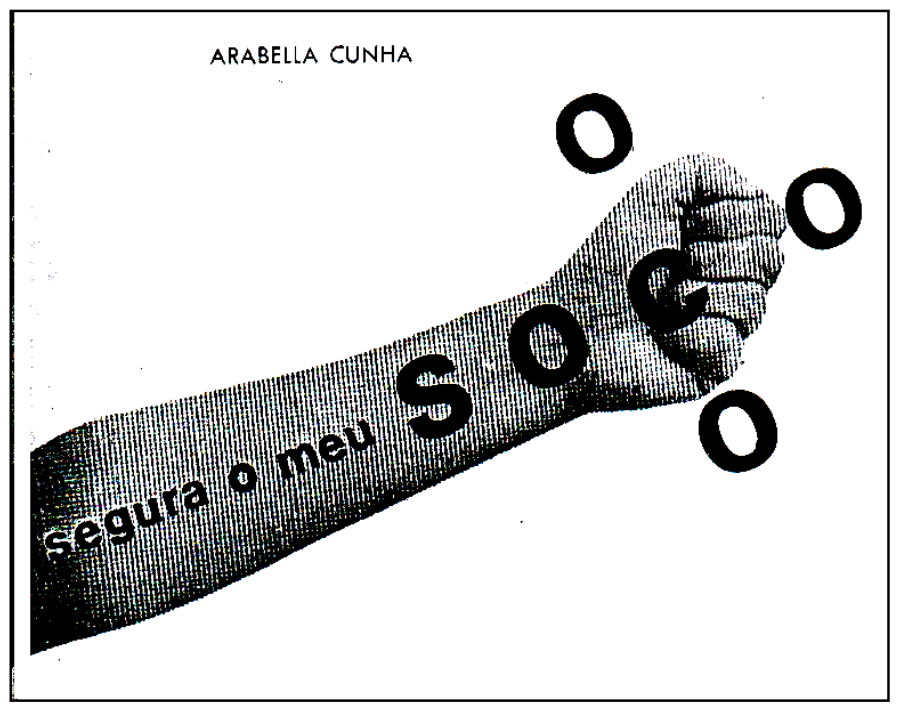


O uso do signo verbal e da figuração no poema anterior contradiz a teoria do poema-processo. Esse é um exemplo de uma das tantas contradições entre teoria e prática presentes na antologia Processo: linguagem e comunicação.

Vale citar aqui os comentários de Philadelpho Menezes sobre essa questão:

(...) encontra-se uma complacência exagerada na aceitação de um sem número de poemas que nada têm a ver com a teoria. Pode-se também entender que a defesa do rótulo "poema-processo" tenha se tornado mais importante que o poema-processo enquanto manifestação particularizada dentro da produção de vanguarda brasileira.

Desse modo, a complacência ter-se-ia transformado numa gula rotulatória só igualável à da poesia concreta, que em certos momentos parecia querer fazer crer a todos que tudo aquilo que não fosse verso na poesia era concretismo (poesia espacializada, caligramas, poesia semiótica e toda a miscelânea visual que assolou a poesia a partir da década de 60). Ao contrário do que os defensores dessa postura deveriam pensar, a ampliação desgovernada e egoísta dos limites do rótulo só tende a dissolver os conceitos e procedimentos tipificadores, criados pelos próprios teóricos e poetas, numa descabida gritaria pela anexação de quinhões maiores do território poético ao seu feudo, numa espécie de privilegiamento da "força política" sem qualquer relação com análises objetivas do fenômeno poético. ${ }^{226}$

Os últimos textos da antologia já indicam a invenção de poemas baseados em uma reformulação de mensagens dos mass media, com o uso de recortes de jornais e revistas e a reprodução de imagens-marcas, irônicas e sem funcionalidade, tendência também notada na última fase da poesia concreta. Nada de novo, quando são lembradas as experiências cubistas:

${ }^{226}$ Op. cit., p.64. 


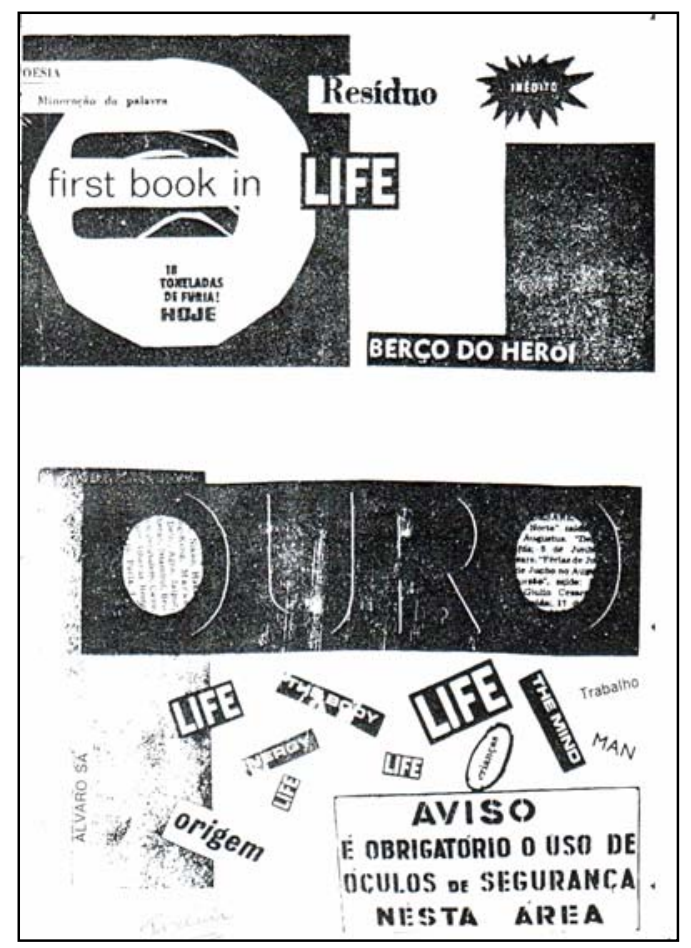

\section{Segundo o texto "Montagem":}

Compete ao poeta reformular a mensagem massificada pelos donos de informação.

* Diferente do Pop que é apenas uma textura do cotidiano. ${ }^{227}$

Até o momento, pouco se falou sobre a participação do leitor/consumidor no poema-processo. O texto seguinte, de Frederico Morais, cita a posição do grupo sobre o assunto:

Contra o poema único, e a partir de uma dada matriz (processo), todo consumidor/ participante poderá construir novas diferentes versões, de acordo com as suas opções particulares. $^{228}$

Observa-se que essa idéia esteve presente em todos os movimentos estudados nesta dissertação, pois previam a participação do leitor na manipulação e recriação de seus produtos. Como se pode notar em "Objeto-Poema”, último texto

\footnotetext{
${ }^{227}$ In: Processo: linguagem e comunicação, cit.

228 "Poema no aterro: ato coletivo". In: Processo: linguagem e comunicação, cit.
} 
que compõe a teoria do poema-processo, sugere-se a criação de um objeto que exija a manipulação:

Objeto-Poema: manipulação da informação: a qualidade comunicativa extra-estética.

(...)

* Elemento de integração física: participação humana.

* Acusar as facilidades do poema-já-processo seria recusar a oferta de conforto da técnica moderna * seria não usar o telefone porque oferece comunicação direta e rápida: do portátil ao relativo (realidade prática).

(...)

* Objeto-Poema: uma ferramenta sem indicação do local onde pegar: o não instrumento (tem um fim próprio).

Relações e decisões sucessivas. Os artistas percebendo o lado social da arquitetura deram maior importância ao ambiental. Do real para o possível: Traduzir em ação... ${ }^{229}$

É importante lembrar que o poema-processo faz, com essa idéia, um retorno às experiências do neoconcretismo que vão introduzir o conceito de manipulação do objeto poético. É o que se pode notar, a seguir, no objeto transparência de Neide de Sá. Outro dado relevante é que os autores de processo, assim como os neoconcretos, defendem a invenção de um objeto sem definições prontas.

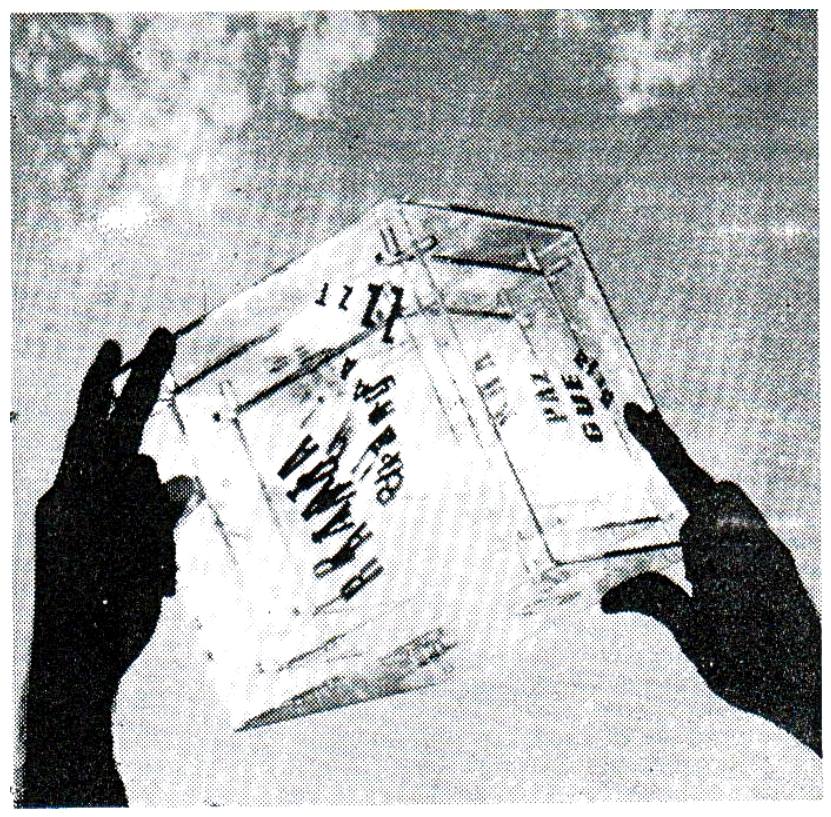

${ }^{229}$ Processo: linguagem e comunicação, cit. 
De um movimento para outro muitas práticas são mantidas. Para o grupo, o poema-processo:

é uma posição radical dentro da poesia de vanguarda. É preciso espantar pela radicalidade. $^{230}$

A nova vanguarda nada propõe de verdadeiramente novo, em termos teóricos, requentando formulações e procedimentos futuristas, cubistas, concretistas, neoconcretistas, praxis etc. Assim, a nobreza teórica parece ter sido suplementada pela tentativa de escandalizar, e o movimento realmente espantou ao realizar em 1968, na sua segunda exposição, uma passeata em que, afirmando que se seguia o princípio oswaldiano da deglutição, em que a invenção e a surpresa espantavam pela radicalidade, seus participantes rasgaram livros de poetas consagrados, como Drummond, Vinícius de Moraes e João Cabral nas escadarias do Teatro Municipal do Rio de Janeiro. ${ }^{231}$

O "rasga-rasga" de livros de poetas discursivos, promovido pelos criadores do poema-processo pretendeu levantar as seguintes questões:

1) um protesto público contra a sigilosa política literária de troca de favores (igrejinhas); 2) a necessidade de mostrar que houve uma ruptura qualitativa no desenvolvimento da poesia brasileira; 3 ) contra o caráter de eternidade no poema que tende sempre ao estável, impedindo o aparecimento do novo; 4) afirmação aos novos poetas de que o tipo de poesia existente nos livros rasgados não lhes pode servir de modelo, pois está superado e consumido; 5) poema é como pilha, gastou gastou (sic); 6) é preciso espantar pela radicalidade. Ao poema radical corresponde uma ação radical. A luta já atingiu o grau de um vale-tudo oswaldiano; 7) o gesto constitui um fato dentro da realidade brasileira e não pode ser visto fora de seu contexto geral. ${ }^{232}$

O "rasga-rasga" reedita o ódio declarado pelo manifesto futurista de Marinetti, em 1912, contra as bibliotecas e os museus. Feito como happening, para escandalizar, funciona como em Marinetti, quando declara a "ânsia de visualizar a

\footnotetext{
${ }^{230}$ Idem.

${ }^{231}$ Manifesto organizado pelos autores do poema-processo em 26 de janeiro de 1968.

232 “ $2^{\mathrm{a}}$ Expo: Escola de Belas-Artes: Janeiro de 1968". In: Processo: linguagem e comunicação, cit.
} 
velocidade". O projeto do poema-processo afirmava então que essa "ânsia" ocorria como "uma fato dentro da realidade brasileira", um fato que não podia "ser visto fora do seu contexto geral". Esse "contexto geral", em 1968, era já o da ditadura militar, que tornava a "ânsia de visualizar a velocidade" muito ambígua politicamente, porque a única velocidade admitida então era a dos processos técnicos de modernização impostos à força das armas e da repressão. "Esse é um país que vai pra frente" e "Ninguém segura esse país" foram lemas da ditadura infelizmente muito conhecidos.

Ou seja: o "rasga-rasga" podia ser apenas uma atitude estética, como se declarou então, de espantar pelo radicalismo. Mas esse radicalismo, efetuado contra a obra de poetas como Drummond, João Cabral e Vinícius de Moraes - os quais, em maior ou menor extensão, sempre defenderam as liberdades civis e a democracia -, não deixava de também reproduzir, nesse momento em que as coisas começavam a se fechar "para valer" (o AI-5 logo seria decretado), o autoritarismo militar que desde 1964 censurava livros e exterminava dissidentes. Além disso, pouco ou nada sobra da experiência do poema-processo, que já na época aparecia como um jogo visual de formas geométricas da indústria, lembrando alguns joguinhos de armar com que se educa a coordenação motora das crianças.

Outra experimentação "radical" do poema-processo ocorreu em Recife: na Feira de Arte da cidade, um pão foi apresentado como poema-processo e comido por todos os presentes. ${ }^{233}$ Segundo Álvaro de Sá, a rasgação dos poemas e a deglutição do pão poema-processo são poemas-processos em versão de happening. Deve-se lembrar que o happening lida com a "estética do precário" em que a "obra" é não-obra, pois não almeja permanecer mais do que o tempo de sua própria execução. O fundamental do happening é estabelecer a ação como informação, dando independência ao ato criativo. Nesses dois atos promovidos pelo movimento, não há poemas-processos, tal como já foram vistos, mas apenas a apropriação de uma ação, como o "rasga-rasga" e um pão que, apresentado como poema-processo, foi literalmente consumido.

\footnotetext{
${ }^{233}$ Processo: linguagem e comunicação, cit.
} 
Jornal do Brasil, 7/4/70, $1^{\circ}$ Caderno.

\section{Pão poema-processo com $2 \mathrm{~m}$ é comido por 5 mil pessoas na Feira de Arte de Recife}

Recife (Sucursal) - Um pão de dois metros de comprimento, apresentalo como poema-processo e comido por todos os presentes, foi a maior atração dia Feira de Arte encerrada ontem nas calçadas das ruas do Pátio de São Pedro, com a participação de 30 jovens artistas pernambucanos.

A Feira, que ficou aberta por três dias, registrou uma afluência de aproximadiamente $5 \mathrm{mil}$ pessoas, que não se importavam de sentar no chẩo a noite inteira para prestigiar os jovens. Estes, cuja idade média era de 18 anos, apresentaram trabalhos cujo índice artístico foi considerado ótimo pela crítica de Recife.

OUTRAS ATRACCOES

Dentre as demals atraçōes (ia Feira de Arte estavam poemas feitos por estudantes de Arquitetura a base de siglas de transito, além de setas e placas de orientação turística. Os objetos mais vendidos, porém, foram os mediaThōes hippies, bólsas e sandálias de couro, que eram adquiridos a precos que variavam de NCr\$ $2,00 \&$ NCr\$ 20,00 .
O pão poema-processo mostrava cartazes que dizism. "Poema-päo feito por grupn de Boa Viagem de parceria com os padeiros" e "Esita abre de arte fol boicotadia pela gloriasa Fundarăo Bienad de São Pqulo." A Fuira fol organizada pela Associaçăo dos Artistas Plásticos de Permambuco e pela Emprêsa de Turismo do Estado.

Talvez a eficiência desses atos, ao promover o consumo rápido, cumprindo o objetivo principal da teoria, tenha levado Álvaro de Sá a dizer:

a rasgação de poemas no rio, o pão-poema do recife e a passeata de pirapora, poemas de confecção e consumo coletivos, são os principais poemas/processo. ${ }^{234}$

O movimento assume então, em prol do consumo, uma diluição total do poema-processo, não se podendo mais falar nem em poema, no sentido adotado pelo grupo. Álvaro de Sá, ao dizer que a "rasgação", o "pão-poema" e a "passeata"

\footnotetext{
234 “Seis teses e alguns corolários sobre a produção da comunicação". Revista de Cultura Vozes, ano 67, n.10,
} p.11, dez. 1973. 
"são os principais poemas/processo", acaba por invalidar a teoria e os poemas criados pelo grupo, pois esses atos só têm em comum com os textos teóricos a idéia de consumo. Wladimir Dias-Pino, principal teórico e idealizador do poemaprocesso, é bastante incisivo quando, em entrevista a Assis Brasil, responde à pergunta: "Que pretende com sua arte?":

- Uma coisa simples para o povo empregar em seus objetos de uso diário. Algo que seja funcional, que possa ser usado na gravata, no tecido, etc., tudo sem esse sentido intelectualizado. Sem uma transcendência mitológica ou lendária. Minha "arte" é contra a personalidade (veja a publicidade americana) e o heroísmo. Uma arte anônima (ou quase) como a do carpinteiro. ${ }^{235}$ 


\section{3. (IN)CONCLUSÃO}

Na primeira parte desta dissertação, observou-se que, no final da década de 1950 e no início dos anos 1960, o convívio da poesia com as artes plásticas brasileiras (pintura, escultura, arquitetura), aliado às ideologias construtivas dos anos 1930 e do início do século e à euforia produzida pela "modernização forçada", resultante do modelo econômico de nacionalismo desenvolvimentista do governo Kubitschek, impulsionou o surgimento da neovanguarda concreta que, em São Paulo, foi liderada por Décio Pignatari e pelos irmãos Augusto e Haroldo de Campos.

A invenção e a integração heróico-cínicas da neovanguarda concreta, lembrando de novo os momentos propostos por Sanguineti, ao sistema internacional do capitalismo industrial avançado, no qual o Brasil permanecia como zona periférica fornecedora de matéria-prima, mantendo inalterada a questão grave da miséria das populações, acabaram provocando vários impasses estético-políticos, teóricos e práticos. Eles foram apontados e criticados pelas neovanguardas rivais, contemporâneas e posteriores, como o neoconcretismo e a poesia praxis. Enquanto a teoria da poesia concreta adotou um racionalismo radical, uma "liberdade doutrinada", na expressão de Enzensberger, pela matematização e semiotização da experiência poética, o neoconcretismo, liderado no Rio de Janeiro por Ferreira Gullar, tendeu a ligar-se à experiência sensível, procurando uma experimentação por assim dizer mais "intimista" das técnicas industriais e dos mass media. Quanto à poesia praxis, produzida como dissensão crítica da poesia concreta, aproximou-se do marxismo, principalmente por meio da categoria central de "trabalho", que utilizou na definição da autoria, do levantamento do campo semântico e da leitura, mas não foi muito adiante, em realizações práticas, das proposições do seu principal teórico, Mário Chamie.

Assim, falando ainda sobre a poesia concreta, vale dizer que, mesmo com suas inúmeras inconsistências teóricas e práticas, ela incidiu criticamente em pontos 
fundamentais das práticas da poesia "tradicional", da crítica literária contemporânea e da historiografia literária. Como se viu no texto citado de Wilson Martins, provavelmente a qualidade estética dos poemas estava aquém da refinada teoria que seus membros propunham, como textos, afinal, sem interesse e descartáveis; mas a intervenção teórica produziu uma situação crítica nova, que foi impossível à crítica existente ignorar, pois, de modo geral, apontava para a crise da arte na sociedade industrial, indicando as aporias da arte na sociedade dominada pelo kitsch e pelo mercado. Além disso, de maneira específica, retomava a herança do movimento modernista de 1922, radicalizando algumas propostas deste para debater a questão da poesia na sociedade brasileira que se modernizava de forma conservadora em pontos de concentração industrial, como a região Sudeste.

$\mathrm{Na}$ segunda parte da dissertação, notou-se no exame da trajetória das poesias de vanguarda uma reprodução dos mecanismos do incipiente mercado brasileiro de arte, que pode ser tratada, como se propôs, por meio da idéia adorniana da vanguarda como expressão da alienação fundamental da sociedade capitalista avançada. De modo geral, com alguma exceção da poesia praxis, o público dessa poesia foi uma abstração.

Outra característica intimamente relacionada à questão da alienação foi a necessidade programática de afirmar o "novo" nas poesias concreta, neoconcreta, praxis e processo. Ela pode ser facilmente observada na proliferação de textos teóricos, que são lançados como tentativa de enumerar mais e mais procedimentos técnicos, princípios formais e conceitos teóricos que, se não são totalmente "novos" - é o caso da reciclagem que quase requenta categorias futuristas, cubistas, construtivistas etc. -, tentam passar algum efeito de novidade quando intervêm nos circuitos restritos da cultura culta de São Paulo e Rio de Janeiro. Suas propostas parecem ter sido importantes principalmente no campo da crítica literária e do ensino das letras nas universidades, que passaram muitas vezes a incluir nos programas de estudo a bibliografia lingüística e semiótica que a poesia concreta citava incansavelmente como argumentos muitas vezes mitológicos de autoridade. As teorias quase sempre acabaram por se tornar mais importantes que a própria 
poesia realmente produzida. Na tentativa de explicar repetidamente a novidade da invenção, que devia constituir seus autores como heróis na ponta do "novo", conforme a idéia de Oswald de Andrade sobre a "medula e osso" na "geléia geral" brasileira, as teorias afirmavam que deixavam para trás o "tradicionalismo" da arte moderna e modernista de poetas como Drummond e Bandeira. Mas os poemas não só se tornaram mera ilustração de teorias prévias, como também se esvaziaram rapidamente de interesse estético no emaranhado de definições polêmicas que acabaram mais por indefinir as propostas e neutralizá-las do que explicá-las de maneira convincente para o leitor. Este ficava quase sempre meio espantado com o aparato matemático-cibernético-lingüístico-semiótico-poético-literário que era mobilizado e, como geralmente os ignorava, também entendia os textos teóricos como se fossem uma espécie de "blablablá" até meio inconseqüente. De todo modo, mesmo os leitores mais informados, como os grandes críticos (Antonio Candido é um deles), entenderam essa poesia como um jogo de permutações que substituía a metáfora expressiva e representativa da poesia anterior por paronomásias ou trocadilhos. O famoso "salto conteudístico-participante" não foi dado, porque não havia realmente condições objetivas para o "pulo da onça". Na hora de a onça beber água, o que se viu foram proclamações que falavam muito de revolução estética, citando Maiakóvski numa sociedade neocolonial, administrada por políticos populistas e, logo depois, por militares.

Podia-se dizer, principalmente, que essas teorias não forneceram elementos teóricos e práticos suficientes para a abolição de si mesmas no momento da sua intervenção. Como neovanguardas, tais movimentos são a ponta da modernidade e, por isso mesmo, teriam necessariamente de prever que o próprio ato da sua invenção, como arte concreta, ou da sua instauração, como praxis, também devia prever sua extinção automática. Afinal, lembrando a origem bélica do termo avantgarde, os heróis que avançam no território do inimigo sabem que são suicidas ou, pelo menos, que não há volta.

No caso da vanguarda estética, a lógica do "novo" moderno não deveria admitir a repetição, porque a modernidade é fundamentalmente anticanônica e 
mesmo acanônica. O poema-processo tentou fazer isso, mas de modo inepto, talvez como mais uma técnica do desenho industrial ou de projetos saídos da prancheta de arquitetos. Quando tentou ser happening, foi happening de modo requentado, porque reciclou e tentou fundir as coisas mais interessantes de praxis, do neoconcretismo e da poesia concreta com uma linguagem aparentemente nova, mas que era realmente velha, datada do tempo dos futuristas e dadaístas do início do século XX. Além disso, foi happening de modo politicamente ambíguo, porque o ato de rasgar livros de poetas que fazem da defesa intransigente da liberdade um dos principais princípios de suas poéticas, como é o caso de Drummond, em um momento em que a ditadura militar fechava o cerco às liberdades civis (1968), não era isento de contradição, podendo mesmo ser entendido como reflexo de uma ideologia tecnocrata.

Ao contrário da sua auto-extinção, porém, o que se observou na mais influente dessas vanguardas, a poesia concreta, nos anos 1960, e 1970, e 1980 e 1990, foi a permanência e a repetição redundantes das proclamações vanguardistas. Bastante cansadas, é verdade, e já transformadas em dispositivos políticos de autoafirmação do poder institucional dos seus principais agentes na universidade e nos media. Não podendo mais escrever versos, eles passaram a dedicar-se a fazer traduções em que se revelaram ótimos poetas tradicionais. Mas as proclamações vanguardistas os transformaram - durante os mais de 40 anos (!) em que incansavelmente falaram do "novo" nos media e na universidade - em defensores de um academicismo estético que, se não recebeu o Nobel por sua qualidade de "poesia de exportação", é pelo menos digno de ser premiado com as melhores cadeiras da Academia Brasileira de Letras. 


\section{POSFÁCIO}

Murilograma a C.D.A.

(...)

E agora, Josés?

Além de Cummings \& Pound

Além de Sousândrade

Além de "Noigandres"

Além de "Terceira Feira"

Além de Poesia-Praxis

Além do texto "Isso é aquilo"

Sereis teleguiados?

Resta a ságoma de Orfeu

Com discurso ou sem.

Sobre a página aberta

Único campo branco

Drummond fazendeiro da cidade

(Esperamos)

Lançará de novo

a semente.

Roma 1965

(Murilo Mendes, 1994, 689-691) 


\section{BIBLIOGRAFIA}

\section{Específica}

AMARAL, Aracy A. (org.). Projeto construtivo brasileiro na arte: 1950-1962. Rio de Janeiro/São Paulo, Museu de Arte Moderna/Pinacoteca do Estado, 1977.

BANDEIRA, Manuel. Apresentação da poesia brasileira. Rio de Janeiro, Edições de Ouro, 1966.

BARBOSA, João Alexandre. As ilusões da modernidade. São Paulo, Perspectiva, 1986.

BASTOS, Oliveira. "A poesia concreta e o problema da comunicação". Jornal do Brasil, Rio de Janeiro, 15 set. 1957. Suplemento Dominical.

BASTOS, Oliveira, GULLAR, Ferreira \& JARDIM, Reinaldo. "Poesia concreta: experiência intuitiva". Jornal do Brasil, Rio de Janeiro, 23 jun. 1957. Suplemento Dominical.

. "Bandeira e a poesia concreta". Jornal do Brasil, Rio de Janeiro, 23 fev. 1958. Suplemento Dominical.

BOSI, Alfredo. "Desdobramentos da vanguarda brasileira". In: História concisa da literatura brasileira. 33.ed. São Paulo, Cultrix, 1994.

BRASIL, Assis. A nova literatura. II. A Poesia.1.ed. Rio de Janeiro, Americana, Brasília, 1975.

BRITO, Ronaldo. “O moderno e o contemporâneo (o novo e o outro novo)”. In: VVAA. Arte brasileira contemporânea. Caderno de Textos 1. Rio de Janeiro, Funarte, 1980. . Neoconcretismo: vértice e ruptura do projeto construtivo brasileiro. 1. ed. Rio de Janeiro, Funarte/Instituto Nacional de Belas Artes , 1985. 
CABRAL, Antônio Carlos. "Poema-praxis e atitude central". O Estado de S. Paulo, São Paulo, 27 jun. 1964. Suplemento Literário.

CAMPOS, Augusto de. Poesia, antipoesia, antropofagia. São Paulo, Cortez \& Moraes, 1978.

. Viva vaia-poesia: 1949/1979. São Paulo, Brasiliense, 1986. . Despoesia. São Paulo, Perspectiva, 1994.

CAMPOS, Augusto de, CAMPOS, Haroldo de, PIGNATARI, Décio. Teoria da poesia concreta. Textos críticos e manifestos (1950-1960). São Paulo, Brasiliense, 1987.

CAMPOS, Haroldo de. "A poesia concreta e a realidade nacional". Revista Tendência, Belo Horizonte, n. 4, 1962. . Xadrez de estrelas - percurso textual:1949/1974. . São Paulo, Perspectiva, 1976.

CANDIDO, Antonio. “A literatura brasileira em 1972”. Arte em Revista, São Paulo, Kairós Ed., ano 1, n.1, jan./mar. 1979. . A educação pela noite e outros ensaios. 2.ed. São Paulo, Ática, 1989. CHAMIE, Mário. Palavra-Levantamento. Rio de Janeiro, Livraria S. José, 1963. . Alguns problemas e argumentos. São Paulo, Conselho Estadual de Cultura, 1969. . Instauração praxis. São Paulo, Quíron, 1974. v.I-II. . A linguagem virtual. São Paulo, Quíron, 1976. . Objeto selvagem. São Paulo, Quíron/Instituto Nacional do Livro, 1977. . "A página Invenção e eu” . Revista de Cultura Vozes, Rio de Janeiro, ano 71, n.1, p.27-30, jan./fev.1977. 
COCCHIARALE, Fernando \& GEIGER, Anna Bella. Abstracionismo; geométrico e informal: a vanguarda brasileira nos anos cinqüenta. Rio de Janeiro: FUNARTE, Instituto Nacional de Artes Plásticas, 1987.

DIAS-PINO, Wladimir. Processo: linguagem e comunicação. 1.ed. Petrópolis, Vozes, 1971.

. A separação entre inscrever e escrever. Cuiabá, Edições do Meio, 25 nov. 1982. (Catálogo de exposição).

FAUSTINO, Mário. Poesia experiência. 3.ed. São Paulo, Perspectiva, 1977.

FLUSSER, Vilém. “Concreto-abstrato”. O Estado de S. Paulo, São Paulo, 6 jun. 1964. Suplemento Literário.

FRANCHETTI, Paulo. Alguns aspectos da teoria da poesia concreta. 1.ed. Campinas, Editora da Unicamp, 1989.

GALLENARI, Maria Aimée Chaguri. Concretismo e neoconcretismo nas artes plásticas: a vanguarda construtiva brasileira nos anos cinqüenta e início dos sessenta. Dissertação de mestrado apresentada à PUC-SP. São Paulo, 1991.

GULLAR, Ferreira. “O poema concreto". Jornal do Brasil, Rio de Janeiro,17 mar. 1957. Suplemento Dominical. . "Poesia concreta: palavra viva". Jornal do Brasil, Rio de Janeiro, 23 fev. 1958. Suplemento Dominical. . Cultura posta em questão. Rio de Janeiro, Civilização Brasileira, 1965. . "Os poetas concretos, 20 anos depois". "Texto/Entrevista", in Revista de Cultura Vozes, Rio de Janeiro, ano 71, n.1, p.99, jan./fev. 1977. . Vanguarda e subdesenvolvimento. Rio de Janeiro, Civilização Brasileira, 1978. . Toda poesia. 9.ed. comemorativa dos 70 anos do autor. Rio de Janeiro, José Olympio, 2000. 
HOLLANDA, Heloisa Buarque de. Impressões de viagem: CPC, vanguarda e desbunde: 1960/70. São Paulo, Brasiliense, 1980.

HOLZHAUSEN, Marlene. Poesia concreta: dois percursos, um diálogo. Tese de doutoramento apresentada à FFLCH-USP. São Paulo, 1996.

JARDIM, Reinaldo. "Flor não é a palavra flor". Jornal do Brasil, Rio de Janeiro, 23 fev. 1958. Suplemento Dominical.

LEITE, Sebastião Uchoa. Participação da palavra poética. Petrópolis, Vozes, 1966.

LINHARES, Temístocles. Diálogos sobre a poesia brasileira: concepção de vanguarda. São Paulo, Melhoramentos, 1976.

LUCAS, Fábio. Vanguarda, história e ideologia da literatura. São Paulo, Cone, 1985.

MALDONADO, Tomás. Vanguardia y racionalidad. Artículos, ensayos y otros escritos: 1946-1974. Barcelona, Gustavo Gili, 1977. (Comunicación Visual).

MARTINS, Wilson. "Destinos da poesia”. O Estado de S. Paulo, São Paulo, 18 jun. 1966. Suplemento Literário.

MENDONÇA, Antonio Sérgio \& SÁ, Álvaro. Poesia de vanguarda no Brasil. Rio de Janeiro, Antares, 1983.

MENEZES, Philadelpho. A trajetória visual da poesia de vanguarda brasileira. Dissertação de mestrado apresentada à PUC-SP. São Paulo, 1987. . Modernidade e pós-modernidade: experimentalismo, vanguarda, poesia. Tese de doutoramento apresentada à PUC-SP. São Paulo, 1991. . A crise do passado: modernidade, vanguarda, metamodernidade. São Paulo, Experimento, 1994. . Roteiro de leitura: poesia concreta e visual. São Paulo, Ática, 1998. 
MERQUIOR, José Guilherme. "Sobre la poesia de vanguardia en el Brasil”. Revista de Cultura Brasileña, Madrid, n.11, t.III, dic. 1964 (numero extraordinario sobre la literatura de vanguardia).

MOURÃO, Rui. “O salto concretista”. O Estado de S. Paulo, São Paulo, 9 set. 1961. Suplemento Literário.

NAVAS-TORÍBIO, Luzia. Gullar's PRE Concretismo NEO. São Luís, Polikron, 1991.

PICCHIO, Luciana Stegagno. História da literatura brasileira. 2.ed. Rio de Janeiro, Nova Aguilar, 1997.

PIGNATARI, Décio. A situação atual da poesia no Brasil. São Paulo, Faculdade de Filosofia, Ciências e Letras de Assis, 1963.

. "Vanguarda como anti-literatura". Revista Convivium (número especial sobre a poesia brasileira), São Paulo, ano IV, n .4/6, jul./ago./set. 1965. . Contracomunicação. São Paulo, Perspectiva, 1971. . Poesia pois é poesia 1950-1975 - Po\&tc 1976-1986. São Paulo, Brasiliense, 1986.

PONTUAL, Roberto. "Poesia: uma nova experiência." Jornal do Brasil, Rio de Janeiro, 26 nov. 1960. Suplemento Dominical. .'O não-objeto verbal como síntese”. Jornal do Brasil, Rio de Janeiro, 17 dez. 1960. Suplemento Dominical. . “A arte próxima: resistência, recomeço e/ou remoção?”. Revista de Cultura Vozes, Rio de Janeiro, ano 64, n.2, mar. 1970.

PRESTES, Rogério Prestes de. Um poeta de vanguarda dialoga com as artes visuais: a transcrição interpoética de Haroldo de Campos. Dissertação de mestrado apresentada à PUC. São Paulo, 1997.

RICARDO, Cassiano. Poesia praxis e 22. Rio de Janeiro, José Olympio, 1966. 
ROCHA, Francisco da. "Sobre a poesia concreta". Jornal do Brasil, Rio de Janeiro, 24 mar. 1957. Suplemento Dominical.

SÁ, Álvaro de. "Seis teses e alguns corolários sobre a produção da comunicação". Revista de Cultura Vozes, Rio de Janeiro, ano 67, n.10, dez. 1973.

SANT'ANNA, Affonso Romano de. Música popular e moderna poesia brasileira. Petrópolis, Vozes, 1978.

. “Os sete erros concretos". Leia, São Paulo, n.98, v.9, dez. 1986.

SCHWARZ, Roberto. O pai de família e outros ensaios. 2.ed. Rio de Janeiro, Paz e Terra, 1992.

SIMON, Iumna Maria \& DANTAS, Vinicius. Poesia concreta. 2.ed. São Paulo, Abril Educação, 1982.

SIMON, Iumna Maria. "Esteticismo e participação: as vanguardas poéticas no contexto brasileiro (1954-1969)”. In: PIZARRO, Ana (org.). América Latina: palavra, literatura e cultura: vanguarda e modernidade. Campinas, Memorial/Unicamp, 1995. 3v.

TEIXEIRA, Ivan. "Rosa e depois: o curso da agudeza na literatura contemporânea (esboço de roteiro)". Revista USP, São Paulo, n.36, p.101-115, dez. 1997/fev. 1998.

TELES, Gilberto Mendonça. Vanguarda européia e modernismo brasileiro. Rio de Janeiro, Record, 1972.

TORRE, Guilhermo de. Historia de las literaturas de vanguarda. Madrid, Guadarrama, 1971. 3v.

VILLAÇA, Alcides Celso Oliveira. A Poesia de Ferreira Gullar. Tese de doutoramento apresentada à FFLCH-USP. São Paulo, 1984.

WYLER, Vivian."25 anos depois, o neoconcretismo revisitado”. Jornal do Brasil, Rio de Janeiro, 1 set. 1984. Caderno B. 
Outras publicações:

Revista Arquitetura e Decoração, n.20, nov./dez. 1956 (especial sobre a I Exposição Nacional de Arte Concreta).

Revista Invenção, 5 números, São Paulo, Edições Invenção, 1962/1967.

Revista Noigandres, 5 números, São Paulo, Edições Invenção, 1952/1962.

Revista Praxis, 5 números, São Paulo, 1962/1966.

Revista Tendência, 4 números, Belo Horizonte, 1957/1962.

\section{Geral}

ADORNO, Theodor W. \& HORKHEIMER, Max. "A indústria cultural - o iluminismo como mistificação de massa". In: Teoria da cultura de massa. Introdução, comentários e seleção de Luiz Costa Lima. 3. ed. Rio de Janeiro, Paz e Terra, 1990.

ADORNO, Theodor W. Teoria estética. Lisboa, Edições 70, 1993.

ANDRADE, Carlos Drummond de. "Uma prosa (inédita) com Carlos Drummond de Andrade". Entrevista com Carlos Drummond de Andrade. Caros Amigos, São Paulo, n. 29, ago. 1999.

ARANTES, Otília. "Depois das vanguardas". Arte em Revista, São Paulo, Kairós Ed, ano 5, n.7, ago. 1983.

. Mário Pedrosa: itinerário crítico. São Paulo, Página Aberta, 1991.

BATTCOCK, Gregory. A nova arte. São Paulo, Perspectiva, 1986. (Debates).

BEHNKE, Kerstin, FABBRI, Paolo, LIMA, Luiz Costa. Crises da representação. Rio de Janeiro, UERJ, 1994.

BENEVIDES, Maria Victoria de Mesquita. O governo Kubitschek: desenvolvimento econômico e estabilidade política (1956-1961). 3. ed. Rio de Janeiro, Paz e Terra, 1979. 
BENJAMIN, Walter. "A obra de arte na época de suas técnicas de reprodução". In: Textos escolhidos. 2. ed. São Paulo, Abril Cultural, 1983. (Os pensadores).

BENSE, Max. Pequena Estética. São Paulo, Perspectiva, 1971.

BERNARDINI, Aurora Fornoni (org). O futurismo italiano: manifestos. São Paulo, Perspectiva, 1980.

BOAVENTURA, Maria Eugênia. A vanguarda antropofágica. 1. ed. São Paulo, Ática, 1985.

BROCH, Hermann. Kitsch, vanguardia y el arte por el arte. 2.ed. Barcelona, Tusquets, 1979.

BÜRGER, Peter. Teoria da vanguarda. 1.ed. Lisboa, Vega, 1993.

DORFLES, Gillo. A arquitetura moderna. Trad. José Eduardo Rodil. Lisboa, Edições 70, 1986.

ECO, Umberto. Obra aberta. 8. ed. São Paulo, Perspectiva, 1991.

ENZENSBERGER, Hans Magnus. “As aporias da vanguarda”. Revista Tempo Brasileiro. Rio de Janeiro, Tempo Brasileiro, v.26-27, p.85-112, jan.-mar. 1971.

FAUSTO, Boris (dir.). História da civilização brasileira. 3.ed. Rio de Janeiro, Bertrand Brasil, 1995. t.III, v.4. “O Brasil Republicano: economia e cultura (1930-1964)”.

FAVARETTO, Celso Fernando. A invenção de Hélio Oiticica. 1.ed. São Paulo, Edusp, 1992.

. Tropicália, alegoria, alegria. 3.ed.São Paulo, Ateliê Editorial, 2000.

FRANCO Jr., Arnaldo. Mau gosto e kitsch nas obras de Clarice Lispector e Dalton Trevisan. Tese de doutoramento defendida na FFLCH-USP. São Paulo, 1999.

FREDERICO, Celso. "A política cultural dos comunistas". História do marxismo no Brasil. MORAES, J.Q. (org.). Campinas, Ed. UNICAMP, 1998. Vol.III. 
HUYSSEN, Andreas. Memórias do modernismo. Trad. Patrícia Farias. Rio de Janeiro, Editora UFRJ, 1996.

LANGER, Susanne K. Sentimento e forma. São Paulo, Perspectiva, 1980.439p. (Estudos).

LIMA, Luiz Costa (introdução, comentários e seleção de textos). Teoria de cultura de massa. 4. ed. Rio de Janeiro, Paz e Terra, 1990.

MARANHÃO, Ricardo. O governo Juscelino Kubitschek. 6.ed. São Paulo, Brasiliense, 1994.

MARTINS, Wilson. A crítica literária no Brasil (1940-1981). Rio de Janeiro, Francisco Alves, 1983. v.II.

MCLUHAN, Marshall. A Galáxia de Gutenberg. A formação do homem tipográfico. São Paulo, Edusp/Nacional, 1972. . Os meios de comunicação como extensões do homem. 4.ed. São Paulo, Cultrix, 1974.

MELO NETO, João Cabral. Obra completa. Rio de Janeiro, Nova Aguilar, 1995.

MENDES, Murilo. Poesia completa e prosa. Rio de Janeiro, Nova Aguilar, 1994.

MERQUIOR, José Guilherme. A razão do poema. Rio de Janeiro, Civilização Brasileira, 1965.

. Arte e sociedade em Marcuse, Adorno e Benjamin. Rio de Janeiro, Tempo Brasileiro, 1969. . Formalismo e tradição moderna: o problema da arte na crise da cultura. Rio de Janeiro, Forense Universitária, 1974

MOLES, Abraham A. Teoria da informação e percepção estética. Rio de Janeiro, Tempo Brasileiro, 1969.

MOTA, Carlos Guilherme. Ideologia da cultura brasileira: 1933-1973. 8.ed. São Paulo, Ática, 1994. 
NOVAES, Adauto (coord.). O nacional e o popular na cultura brasileira: artes plásticas e literatura. São Paulo, Brasiliense, 1982.

ORTIZ, Renato. A moderna tradição brasileira. São Paulo, Brasiliense, 1988.

PAES, Maria Helena Simões. A década de 60. São Paulo, Ática, 1992. (Princípios).

PAZ, Octavio. Signos em rotação. São Paulo, Perspectiva, 1972. (Debates). . Os filhos do barro: do romantismo à vanguarda. Trad. Olga Savary. Rio de Janeiro, Nova Fronteira, 1984.

PEDROSA, Mário. Mundo, homem, arte em crise. 2.ed. São Paulo, Perspectiva, 1986. . Forma e percepção estética: textos escolhidos II. Otília Arantes (org.). São

Paulo, Edusp, 1996. . Acadêmicos e modernos: textos escolhidos III. Otília Arantes (org.). São Paulo, Edusp, 1998.

PERLOFF, Marjorie. O movimento futurista. Trad. Sebastião Uchoa Leite. São Paulo, Edusp, 1993.

PESSOA, Fernando. Álvaro de Campos. Ficções do Interlúdio. In: Pessoa, Fernando. Obra Poética. Volume único. Rio de Janeiro, Aguilar, 1969.

POLI, Francesco. Producción artística y mercado. Barcelona, Barcelona Editorial, Gustavo Gili, 1976.

RODRIGUES, Marly. A década de 50: populismo e metas desenvolvimentistas no Brasil. 4. ed. São Paulo, Ática, 1999. (Princípios).

ROSENBERG, Harold. A tradição do novo. São Paulo, Perspectiva, 1974. (Estudos).

SANGUINETI, Edoardo. Ideologia e linguagem. Porto, Portucalense, 1972. . Por una vanguardia revolucionaria. Buenos Aires, Tiempo Contemporaneo, 1972.

SARAIVA, Arnaldo. A vanguarda e a vanguarda em Portugal. Porto, Portucalense, 1972. 
SCHWARTZ, Jorge. Vanguardas latino-americanas: polêmicas, manifestos e textos críticos. São Paulo, Edusp/Iluminuras/Fapesp, 1995.

ZANINI, Walter (coord.). História geral da arte no Brasil. Cidade. Instituto Walter Moreira Sales, 1982. v.II. 